\title{
The First Amendment in Its Forgotten Years
}

\author{
David M. Rabban ${ }^{\dagger}$
}

\section{TABLE OF CONTENTS}

I. Free Speech Before the Courts 522

A. Supreme Court Cases 524

1. Avoiding First Amendment Issues 525

Resisting Incorporation into the Fourteenth Amendment $\quad \mathbf{5 2 5}$

Excluding Publications from the Mails 526

Neglecting First Amendment Issues $\quad 529$

Limiting the Meaning of Speech 531

2. Addressing First Amendment Issues 533

Justice Holmes and the Bad Tendency of Speech 533

Review of Statutes Penalizing Speech $\quad 536$

The First Amendment as the Embodiment of English Common Law 539

3. Hints of Protection 540

4. Summary 542

B. Decisions Based on State Law 543

1. The Bad Tendency Doctrine 543

Speech by Radicals $\quad 543$

Obscenity and Public Morals $\quad 548$

2. Libel $\quad 550$

3. Political Speech 551

4. Labor Injunctions 553

5. Speech in Public Places 555

C. The Judicial Tradition 557

† Counsel, American Association of University Professors. 
Prewar Free Speech

II. Legal Scholarship $\quad 559$

A. The Social Interest in Free Speech 563

B. The Distinction Between Public and Private Speech 564

1. Schofield's Formulation of the Distinction 564

2. Other Scholarly Support for the Distinction 566

C. The Expanding Conception of Free Speech 568

D. The Rejection of Blackstone 570

E. The Limits of Protected Speech 572

1. The Direct Incitement Test 572

2. Pound's Balancing Test 575

3. Schroeder's Test of Actual Injury 576

4. The Benefits of Libertarian Standards 578

F. The Heritage of Prewar Scholarship 579

III. The Role of the Prewar Tradition in the Early Development of Modern First Amendment Doctrine

A. The Selective Draft Law Cases 581

B. The Espionage Act Cases 582

1. Defendants' First Amendment Arguments 582

2. The Government's Response 584

3. The Unanimous Opinions by Holmes and Brandeis

584

C. Zechariah Chafee, Jr., and the Selective Use of the Prewar Tradition

1. Chafee's Reliance on the Prewar Scholars 586

2. Chafee's Misrepresentation of Judicial Precedent 589

D. The First Amendment Dissents by Holmes and Brandeis 


\section{The First Amendment in Its Forgotten Years*}

Contemporary scholars of the free speech clause of the First Amendment generally trace its modern development from the Espionage Act $^{1}$ passed shortly after the United States entered World War One. They regard the resulting cases ${ }^{2}$ as the first important judicial decisions, and the articles and book published by Zechariah Chafee, Jr., from 1918 through $1920^{3}$ as the seminal legal scholarship. Chafee's writ-

* Copyright (C) 1981 by David M. Rabban. My interest in searching for a First Amendment tradition before World War One grew out of courses taught by Yosal Rogat and Gerald Gunther at Stanford Law School in 1973 and 1974. Both professors placed great emphasis on the first Espionage Act cases and especially on the importance of Judge Learned Hand's decision in Masses Publishing Co. v. Patten, 244 F. 535 (S.D.N.Y.), rev'd, 246 F. 24 (2d Cir. 1917), as a doctrinal alternative to the Supreme Court opinions written by Justice Holmes in March 1919. See Gunther, Learned Hand and the Origins of Modern First Amendment Doctrine: Some Fragments of History, 27 STAN. L. REv. 719 (1975). Yosal Rogat also pointed out some of the similarities between several of Justice Holmes' prewar decisions and his Espionage Act opinions. Professors Rogat and Gunther thereby questioned the prevailing assumption that Schenck v. United States, 249 U.S. 47 (1919), marked the beginning of First Amendment adjudication. After taking their courses, I thought it likely that the turbulent history of the late nineteenth and early twentieth centuries had produced other cases and had provoked legal scholarship on the First Amendment that also preceded Schenck.

I owe my greatest debt to Gerald Gunther, who encouraged my interest in undertaking this research when neither of us knew what, if anything, I might find. For many years and in countless ways, he has supported my efforts to develop my original seminar paper, The Meaning of the First Amendment in the Generation Before World War One (May 31, 1974) (unpublished seminar paper, Stanford Law School), ciled in Gunther, supra, at 723 n.14.

Andrew Lipps has read every draft of every manuscript I have written on this topic and has had many useful suggestions throughout. His willingness to read sections of a manuscript as soon as I completed them kept me on track and provided invaluable intellectual companionship during the lonely process of writing. Jonathan Knight and Jamic Kalven made exceptionally detailed and helpful criticisms of the long manuscript from which this article has been extracted. I am also grateful for the substantive written and oral comments I have received about the long manuscript from Jerold Auerbach, Mary Gray, Andrew Irving, Staughton Lynd, Walter Metzger, Paul Murphy, Philip Pomper, William Van Alstyne, and Robert Webb. Erika Chadbourn, Curator of Manuscripts and Archives, Harvard Law School Library, has been an excellent guide to the Brandeis, Chafee, and Holmes Papers.

A fellowship awarded by Project '87, jointly sponsored by the American Historical Association and the American Political Science Association, allowed me to spend four months as a guest at the Brookings Institution, where I did most of the work on this article. Francis Rosenberger and Philip Argetsinger, the Director and Assistant of Project '87, did much to make my fellowship productive. I also thank James MacGregor Burns and Richard B. Morris, the cochairmen of Project ' 87 , for the personal interest they have taken in my research.

1. Act of June 15, 1917, ch. 30, tit. 1, $\$ 3,40$ Stat. 217 (current version at I8 U.S.C. $\S 2388(a)(1976))$.

2. See, e.g., Schenck v. United States, 249 U.S. 47 (1919); Frohwerk v. United States, 249 U.S. 204 (1919); Debs v. United States, 249 U.S. 211 (1919); see Espronage AGr CASES (W. Nelles ed. 1918) (excerpts from federal district and circuit court opinions).

3. Z. Chafee, Freedom of Speech (1920); Chafee, A Contemporary State Trial-The 
ings were prompted by and concentrated on the highly controversial Espionage Act prosecutions and decisions. Although he devoted some attention to the origins and early history of the First Amendment, Chafee essentially ignored the years between the Sedition Act of 1798 and the Espionage Act of 1917.*

For decades, scholars and judges accepted Chafee's interpretation of First Amendment history. In 1960, however, Leonard Levy wrote Legacy of Suppression, which effectively challenged Chafee's libertarian understanding of the original meaning of the First Amendment. ${ }^{5}$ Scholars have also refuted the libertarian connotation Chafee ascribed to the phrase "clear and present danger" in the opinion Justice Holmes wrote in Schenck v. United States, one of the first Espionage Act cases decided by the Supreme Court. ${ }^{6}$ More recently, Gerald Gunther has stressed the importance of Judge Learned Hand's earlier opinion in Masses Publishing Co. $\%$. Patten, ${ }^{7}$ decided the month after Congress passed the Espionage Act. But the period between 1798 and 1917 has remained inadequately explored.

Some historians have investigated particular free speech issues between the ratification of the First Amendment and World War One.

United States Versus Jacob Abrams Et Al., 33 Harv. L. REv. 747 (1920); Chafee, Freedom of Spech in War Time, 32 Hakv. L. REv. 932 (1919) [hereinafter cited as Chafee-Freedom of Speech in War Time]; Chafee, Freedom of Speech, 17 Ncw Republic 66 (1918) [hereinafter cited as Chafee-Freedom of Speech].

4. See Chafee-Freedom of Speech in War Time, supra note 3, at $945-47$ (framers intended to abolish common-law crime of sedition); id. at 944 (prewar cases too few and varied to define boundary between protected and unprotected speech). In an introductory "bibliographical note," Chafee made an understatement that remains true more than sixty years later. He observed that "[t]he history of freedom of speech in America has not yet been fully investigated." Chafee cited only one historical work, a history of freedom of the press in Massachusetts to 1827 . Id. at 933 n.1. But see id. at 938-42 (passing references to several decisions before World War One).

5. L. LEVY, LegACY of SupPREssion (1960). In his "revisionist" interpretation, Levy reluctantly concluded that the framers did not intend to abolish the common-law crime of seditious libel and that the Bill of Rights reflected "political expediency" rather than "principled commitment to personal liberties." Id. at vii-viii. Nor did the framers intend to "supersede the common law by repudiating the Blackstonian concept that freedom of the press meant freedom from prior restraint" or to abolish "the power of government to punish words that do not directly incite to acts in violation of law." Id. at $\mathrm{x}$. Levy argued that Chafee and others " 'anticipated the past' by succumbing to an impulse to recreate it so that its image may be seen in a manner consistent with our rhetorical tradition of freedom, thereby yielding a message which will instruct the present." Id. at 2.3; see Letter from Leonard Lery to Felix Frankfurter (Nov. 12, 1958) (Felix Frankfurter Papers, Box 76, Library of Congress) ("liberals had been playing ... fast and loose with skimpy evidence"). Contra, Kalven, The New York Times Case: $A$ Note on "The Central Meaning of the First Amendment", 1964 Sup. Cr. Rev. 191, 221 n.124; Anastaplo, Book Review, 39 N.Y.U. L. REv. 735 (1964).

6. 249 U.S. 47 (1919); see p. 580 \& note 357 infra.

7. Gunther, supra note *; see 244 F. 535 (S.D.N.Y.), rev'd, 246 F. 24 (2d Cir. 1917). 
They have studied the Sedition Act of $1798,{ }^{8}$ controversies over the mailing of antislavery literature before $1860,{ }^{9}$ the treatment of dissenting speech during the Civil War, ${ }^{10}$ the development of academic freedom in the United States, ${ }^{11}$ and the "free speech fights" by the Industrial Workers of the World (IWW) in the early twentieth century. ${ }^{12}$ But none of these studies treats judicial or scholarly commentary on the First Amendment in detail, and no scholar has made a comprehensive attempt to generalize about the theoretical or practical meaning of the First Amendment ${ }^{13}$ during any period between 1798 and $1917 .{ }^{14}$ The impression left by Chafee and reinforced by

8. See, e.g., L. LEvy, supra note 5, at 237-48, 258-308; J. Miller, CRISIS in FreedoM (1951); J. SMITh, FREEDOM's FetTERs (1956); Berns, Freedom of the Press and the Alien and Sedition Laws: A Reappraisal, 1970 Sur. Cr. Rrv. 109; Carroll, Freedom of Speech and of the Press in the Federalist Period; The Sedition Act, 18 Mich. L. Rev. 615 (1920).

9. See, e.g., C. Edton, The Freedom-of-Thought Struggle in the Old South 196-215 (rev. ed. 1964); R. Nye, Fettered Freedou 41-85 (rev. ed. 1963); W. Savage, The ControVERSY OVER THE DISTRIBution of ABolition Literature, 1830-1860 (1st ed. 1938).

10. E. M. Covlter, The Confeuerate States of AMericA, 1861-1865, at 501-06 (1950); J. Randall, Constitutional. Problems Under Lincoln 74-95, 176-79, 477-510, 520, 526.28 (rev. ed. 1951).

11. R. Hofstadter \& W. Metzger, The Development of Academic Freedom in the United States (1955); see H. Beale, A History of Freedom of Teaching in AMerican Schools (1941).

12. See, e.g., M. Dubofsky, We Shall BE All 173-97 (1969); 4 P. Foner, Histori of the Labor Movement iN THE United States 172-213 (1965). See generally W. Preston, Aliens And Dissenters 35-62 (1963). David Montgomery contends that the direct action techniques of the IWW were "the main theme of a dozen years of fierce class conflict in America" between 1909 and 1922 and that "the customary image of the IWW as representing conduct and aspirations far removed from the 'mainstream' of American labor development may be misleading." D. MONTGomery, Workers' Control in AMERICA 91, $100(1979)$.

Recent scholarship has provided important insights into broader relationships between Iabor agitation and free speech in the decades before World War One. For illuminating discussions of the cultural and economic background of the street demonstrations that accompanied strikes and lockouts during this period, see H. GutMan, Work, Culture, ANd Society in INDUSTRI.slizing America 63-66 (1976), and D. Montgomery, supra, at 101-05. These authors also emphasize the relationships between the local balance of power and the treatment of workers' free speech claims. See H. GuTMaN, supra, at 248-54; D. MONTGoMery, supra, at 59, 160. Montgomery concludes that local enforcement of vague ordinances prohibiting trespass and disorderly conduct had a more significant impact on the success of picketing and strikes than court injunctions or legislation. Id.

13. This article uses the term "First Amendment" generally to refer to issues and cases that the modern reader would recognize as relating to freedom of speech and freedom of the press.

14. There has, however, been some published discussion of the legal treatment of free speech issues during the nineteenth and early twentieth centuries. See, e.g., $\mathrm{L}$. Whipple, The Story of Civil Liberty in the United States (1927) (recounting in rough historical sequence from 1776 to 1917 episodes of public intolerance and governmental repression of minorities, without analyzing judicial doctrine regarding free speech); Anderson, The Formative Period of First Amendment Theory, 1870-1915, 24 AM. J. Legal Hist. $56(1980)$ (focusing on restrictive municipal ordinances and briefly discussing aca- 
subsequent scholars thus persists, and analysis of the modern development of free speech doctrine still generally begins with the Espionage Act litigation. ${ }^{15}$

There was, in fact, a marked increase in legal analysis of the First Amendment in the years following World War One. There were more prosecutions, more judicial decisions, and more scholarly articles and books. Perhaps of greatest importance, World War One and its aftermath made a greater number of influential people sensitive to First Amendment concerns. ${ }^{16}$

This postwar activity, however, did not spring from a void. During the generation that preceded World War One, the consequences of industrialization led to substantial social unrest and radical activity. The industrial violence associated with the Homestead and Pullman strikes in the 1890 s, the fear of anarchists generated by the Haymarket riot of 1886 and revived by the assassination of President McKinley in 1901, the nativist response to mass immigration, and the notoriety of the IWW and Emma Goldman in the early 1900 s are among the best known examples. ${ }^{17}$ It is not surprising that this turbulent period tested the legal meaning of free speech. The subsequent neglect of the prewar years has left a distorted view of the social and intellectual history of the First Amendment.. ${ }^{18}$

demic debate); Roche, Civil Liberty in the Age of Enterprise, 31 U. CHI. L. REv. 103 (1963) (general discussion of civil rights of racial and religious minorities, socialists, and trade unionists).

15. Only a few scholars have tried to account for the assumed absence of First Amendment interpretation over such an extended period. See, e.g., IW. Berns, The First AmendMINT ANd the Future of American Democracy 147-48 (1976) (no federal libel statute since 1801 and no federal jurisdiction over common-law crimes since 1812); J.W. HuRST, L.1W AND THE CONDITIONS OF FREEDOM 31-32 (1956) (America in nineteenth century "cxalted individual liberty" in abstract, manifested no "substantial, defined hostility to individual political freedoms," but reacted with indifference or impatience to any distraction from economic growth); P. Murphy, The Mesning of Freedom of Spefch 248 (1972) (except for 1798 Sedition Act, no federal legislation and few state statutes limited frec specch); Roche, supra note 14, at 103-04 (American political thought before twentieth century defined civil rights in "essentially majoritarian fashion as safeguards against oppressive governmental action," not as "minority rights").

16. See, e.g., D. Johnson, The Challenge to American Freedoms 194-98 (1963) (study of World War I and rise of American Civil Liberties Union); P. MURPHY, W'orLd War I AND THE ORIgin OF Civil Liberties in the United States (1979).

17. See R. Wirbe, The Sesrch for Order (1967). See generally Thomas, Nationalizing the Republic, 1990-1920, in B. Bailyn, D. Davis, D. Donald, J. Thomas, R. Wiebe, \& G. Wood, The Griat Republic 827-978 (1977) (general textbook treatment of period).

18. The prewar period is particularly intriguing because it immediately precedes the time when serious attention to the First Amendment is commonly thought to originate. The existence of scholarly and judicial encounters with free speech claims in the gencration before World War One also suggests that it would be fruitful for contemporary scholars to examine carlier periods of American history for evidence of an older First Amendment tradition that may have been lost. 
Scholarship and judicial decisions before the war often foreshadowed and influenced subsequent developments in ways that the postwar civil libertarians never fully understood and occasionally misrepresented. In the decades prior to Schenck, a rather wide range of free speech cases, including several arising out of radical activity, did reach the Supreme Court. Some referred directly to the First Amendment. Others raised questions that courts today would recognize as free speech issues, although the Supreme Court, and sometimes even the litigants, often did not identify them as such. A few scattered hints of doctrine emerged from this litigation, particularly judicial reliance on the possible "bad tendency" of speech as a justification for penalizing it. The Supreme Court, with one minor exception, uniformly found against the free speech claimants. Decisions by other courts were generally as restrictive, although some did support free speech.

Legal scholarship before the war also explored the meaning of freedom of expression, often in remarkably sophisticated terms and often with considerable concern for the importance of free speech to the individual and to society. Important scholars such as Thomas Cooley, Ernst Freund, Roscoe Pound, and Henry Schofield analyzed these issues before Zechariah Chafee, Jr., entered the field. Theodore Schroeder, the principal figure in the Free Speech League, an important precursor of the American Civil Liberties Union, wrote extensively on freedom of expression during this period. ${ }^{19}$ These scholars strongly criticized the prevalent judicial insensitivity to free speech.

19. The Free Speech League, founded in 1902 and incorporated in 1911, was the leading defender of free speech prior to World War One. The League was an informal organization consisting of a few intellectuals and professionals who lived in New York City. Its members dedicated themselves to protecting freedom of expression for all groups and in all contexts at a time when almost all Americans, including the future leaders of the American Civil Liberties Union and other postwar civil libertarians, were generally unconcerned about this issue. Most of the information available on the League is contained in the private papers of Theodore Schroeder, its most important member. Schroeder's papers are located in the Library of Southern Illinois University at Carbondale. Other active members of the League included the well-known journalists Hutchins Hapgood and Lincoln Steffens, and Gilbert E. Roe, a former law partner of Senator Robert M. LaFollette and a practicing attorney who handled many free speech cases, including Fox v. Washington, 236 U.S. 273 (1915), State v. Boyd, 86 N.J.L. 75, 91 A. 586 (Sup. Ct. 1914), rev'd on other grounds, 87 N.J.L. 560, 94 A. 807 (Ct. Err. \& App. 1915), People v. Sinclair, 86 Misc. 426, 149 N.Y.S. 54 (Ct. Gen. Sess. 1914), Masses Publishing Co. v. Patten, 244 F. 535 (S.D.N.Y.), rev'd, 246 F. 24 (2d Cir. 1917), and Debs v. United States, 249 U.S. 211 (1919), see pp. 534-36, 545-47, 582-84, 588 n.415 infra (discussing those cases).

The Free Speech League has received little attention. But see P. Murphy, supra note 15 , at 19-20, 31, 291-92. The few works that even mention it usually identify the League incorrectly as nothing more than the organizational identity for Schrocder's personal 
The decisions of the Supreme Court in cases brought under the Selective Draft Law and the Espionage Act, both passed in 1917, extended the prewar judicial tradition of hostility to First Amendment claims. But Chafee's articles and book, relying heavily on the prewar scholarship, advocated an alternative, libertarian construction of the First Amendment. Chafee skimmed over the cases before World War One and misread Schenck, a decision essentially consistent with the prewar tradition that Holmes' own earlier opinions had helped to establish.

The Supreme Court's majority decisions in the 1920s continued to apply the bad tendency doctrine to reject First Amendment claims. But Justices Holmes and Brandeis, who had written the unanimous opinions in the first group of Espionage Act cases in March 1919, began to dissent in Abrams 0 . United States, ${ }^{20}$ decided eight months later. In their dissents, Holmes and Brandeis incorporated many of the libertarian doctrines advocated by Chafee in Freedom of Speech in War Time, an article published after Schenck but before Abrams in the June 1919 issue of the Harvard Law Review. They also followed Chafee's incorrect interpretation of "clear and present danger" and continued his neglect of the prewar cases, steps that helped conceal the significant doctrinal innovations they were promoting. In the 1930s, the Supreme Court majority ${ }^{21}$ began to accept many of the libertarian values expressed in the earlier dissents by Holmes and Brandeis. Through this process, many ideas of the prewar scholars became part of modern First Amendment doctrine, while the earlier tradition of judicial hostility to free speech was conveniently forgotten.

efforts. See, e.5., D. JohNson, supra note 16, at 195; Auerbach, Introduction to T. SchroEdir, "Obscene" Literiture and Constitutional Law at v, xi (reprint ed. 1972); The Reminiscences of Roger Baldwin 114 (1954) (Oral History Collection, Columbia University); D. Brudnoy, Liberty's Bugler: The Seven Ages of Theodore Schroeder 144-45, 193, 195. 216 (April 1971) (unpublished Ph.D. dissertation in Brandeis University Library). In a forthcoming article on the Free Speech League, I intend to demonstrate the range and importance of its activities as well as its crucial link to Roger Baldwin during the formative years of the American Civil Liberties Union.

The most comprehensive account of Schroeder's life and work is found in an unpublished dissertation. D. Brudnoy, supra. See also Domayer, Theodore Schroeder: A Biographical Sketch, in Theodore Schroeder, A Cold ENThUsinst 1-4 (R. McCoy ed. 1973) (on file with Yale Law Journal); H. Hapgood, A Cold Enthusiast (1913) (pamphlet on file with Yale Law Journal). Schroeder is discussed in several autobiographies by people who knew him, including the illuminating reminiscences of Roger Baldwin, supra, at 113-15.

20. 250 U.S. 616, 624 (1919).

21. See, e.g., Hague v. C.I.O., 307 U.S. 496 (1939); Herndon v. Lowry, 301 U.S. 242 (1937); DeJonge v. Oregon, 299 U.S. 353 (1937); Near v. Minnesota, 283 U.S. 697 (1931); Stromberg v. California, 283 U.S. 359 (1931). 


\section{Free Speech Before the Courts}

Scholars generally assume that courts were not asked to resolve free speech issues until Congress passed the Espionage Act in 1917.:No major casebook on constitutional law highlights a First Amendment decision before 1917, and few casebooks even refer to any prior free speech developments. ${ }^{23}$ The force of this common assumption is emphasized by the fact that, in the very process of revising the First Amendment tradition, two preeminent legal scholars still begin their analyses with the Espionage Act litigation. ${ }^{24}$

Scores of decisions reported from all levels of the judicial system in the generation before World War One demonstrate that this assumption is incorrect. These cases arose in a striking variety of factual contexts. Many grew out of the social unrest of the period: workers, anarchists, socialists, and religious minorities produced much of the free speech litigation before the war. But cases involving editors and publishers, businessmen, movie distributors, candidates for

22. See, e.g., W. BERNS, supra note 15 , at 148 (first free speech case reached Court in 1919); L. Friedman, A History of AMERICAN LAw 578 (1973) (“A corpus of law about free speech was first seriously constructed in the period of and after the First World War."); P. MURPHY, supra note 15, at 4 ("In America, freedom of speech had been an operational reality largely outside the area of either legal definition or restriction from the adoption of the Bill of Rights until World War I . . .."); Chafec, Thirly-Five Ycars with Freedom of Speech, I U. K.IN. L. REv. 1, 1 (1952) (until beginning of World War One, meaning of First Amendment "remained conjectural"; no "authoritative judicial interpretation" before 1917) [hereinafter cited as Chafee-Thirly-Five Years]; Emerson, The Doctrine of Prior Restraint, $20 \mathrm{LAw} \&$ Contemp. Prob. 648, 652 (1955) (Coutt did not "begin to explore the implications of the constitutional guarantee for freedom of expression" until Espionage Act prosecutions); Greenawalt, Speech and Crime, 1980 AM. Bar Foundation Resedrch J. 647, 693-94 (stating that Court development of First Amendment doctrine began with Espionage Act cases, but cites prewar treatise, state court de. cision, and L.R.A. annotation); Gunther, supra note *, at 722 ("[a]ccording to the traditional view of the intellectual history of the first amendment, . . . all high points of the formative ycars" occurred between summer of 1918 and spring of 1921). See generally D. KENNEDY, OVER HERE 84, 86 (1980) (historical study of domestic effects of World War One). But see note 14 supra (citing studies of prewar period).

23. See, e.g., E. Barretr, Constitutional Law 1122-31 (5th ed. 1977); P. Brest, ProCesses of Constitutional Decisionmaking 146-54 (Supp. 1977); P. Freund, A. Sutherland, M. Howe, \& E. Brown, Constitutional Law 1130-31, 1137 (4th ed. 1977); G. Gunther, Cases and Materials on Constitutional Law 1118-37 (10th ed. 1980); P. Kiuper \& F.

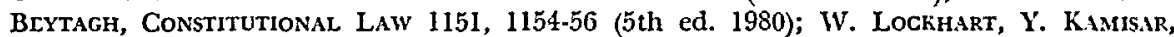
\& J. Choper, Constitutional Law 650-65 (5th ed. 1980). One casebook, 1 N. Dorsen, $P$. Bender, \& B. Neuiborne, Emerson, Haber, ind Doksen's Politicil and Civil Rights in THE UNITEd STATES (4th ed. 1976), briefly discusses several of the prewar Supreme Court cases analyzed in this article, $i d$. at 28,31 , and contains a useful section on the history of free speech in the United States before World War One, id. at 20-39.

24. Gunther, supra note *, at 722 (stressing Masses Publishing Co., decided by Hand in summer 1917); Kalven, Professor Ernst Freund and Debs v. United States, 40 U. CHr. L. REv. 235, 236 (1973) (First Amendment law originates in Debs as well as Schenck in 1919). Gunther does briefly summarize "the practical and doctrinal climate of the times, so strikingly inhospitable to dissent," with footnote references to four prcwar cases. Id. at 724 . 
political office, and government employees also brought First Amendment issues to judicial attention. These decisions provide fascinating proof that litigation about freedom of expression is not just a relatively recent phenomenon.

The overwhelming majority of prewar decisions in all jurisdictions rejected free speech claims, often by ignoring their existence. No court was more unsympathetic to freedom of expression than the Supreme Court, which rarely produced even a dissenting opinion in a First Amendment case. Most decisions by lower federal courts and state courts were also restrictive, although there were some notable exceptions. Radicals fared particularly poorly, but the widespread judicial hostility to the value of free speech transcended any individual issue or litigant.

This pervasive hostility did not emerge from a coherent theoretical framework. The cases were as doctrinally sparse as they were factually diverse. Like many decisions in all areas of the law before World War One, these First Amendment cases typically invoked formal pieties at the expense of rigorous analysis, ${ }^{25}$ thus precluding the interchange and criticism necessary to the evolution of doctrine. At the same time that they issued platitudes about the importance of First Amendment values, judges failed to recognize free speech claims. Even when the courts addressed the free speech issues presented, they generally resolved them on an ad hoc basis. Courts rarely went beyond the facts of a particular case to articulate fundamental principles of interpretation. As Chafee pointed out, "[n]early every free speech decision ... appears to have been decided largely by intuition," 26 and the intuitions of conservative judges rarely supported freedom of expression.

The absence of systematic judicial thought makes it difficult to divide the prewar cases into analytical categories, but some generalizations are possible. Opinions constantly reiterated that the First Amendment and analogous provisions of state constitutions do not

25. See K. Llewelly, The Common Law Tradrion 38-40 (1960) (identifying and describing "formal style" of appellate decisions during this period). Writing about this "age of faith," Gilmore concludes,

the judges, like the professors, rarely, if ever, bothered with the facts of the cases they cited or with the reasons why the cases had been decided as they had been. Nor did the judges make any attempt to explain the reasons for their decisions. It was enough to say: The rule which we apply has long been settled in this state (citing cases). Indeed, it was improper, unfitting, unjudicial to say more. The juice of life had been squeezed out; the case reports became so many dry husks. Stare decisis reigned supreme.

G. Gilmore, The ages of American Law 63 (1977).

26. Chafee-Freedom of Speech in War Time, supra note 3 , at 945. 
protect "license" or the "abuse" of speech. Using this rationale without defining the boundary between "free" speech and "license" or "abuse," courts routinely restricted speech in public places and developed the labor injunction. Courts also punished libel, obscenity, and "indecent" publications, pointing out that the First Amendment did not abolish preexisting liability at common law. Many decisions, including an important Supreme Court opinion by Justice Holmes, followed Blackstone's conclusion that free speech precludes prior restraints, but permits the punishment of publications, regardless of truth, for their tendency to harm the public welfare. ${ }^{27}$ In striking contrast to their increased oversight of economic and social legislation, judges gave great deference to the "police power" $=$ of legislators and administrators to determine the tendency of speech. Judges also readily found that speech, even if not directly prohibited, had a tendency to produce an action proscribed by statute and therefore could be penalized as a violation of the more general law.

The judicial landscape, however, was not unrelievedly bleak. A few Supreme Court opinions contained some fragments of theory and hints of a more tolerant attitude toward freedom of expression. In addition, a minority of state and lower federal courts provided substantial protection for free speech, and several evaluated the meaning of the First Amendment with extraordinary care and sophistication, even by more recent standards.

The very existence of the prewar cases requires a reevaluation of the intellectual history of the First Amendment. These cases reveal that the crucial postwar decisions, from which current analysis generally begins, continued an established pattern of hostility to First Amendment concerns. This tradition had to be ignored or repudiated in order to create the modern libertarian interpretation of the First Amendment. The following pages reconstruct the prior lost tradition by examining the Supreme Court cases and a selection of cases based on state law that implicated free speech in the generation before World War One.

\section{A. Supreme Court Cases}

The Supreme Court's prewar decisions confined First Amendment protection to a relatively narrow range of cases. During this period,

27. Patterson v. Colorado, 205 U.S. 454, 462 (1907); see notes 86 \& 299 infra (Blackstone's formulation of freedom of speech).

28. Freund defined the "police power" as "the power of promoting the public welfare by restraining and regulating the use of liberty and property." E. Freund, The Police Power at iii (1904). 
the Court refused to apply the First Amendment to state action, found no First Amendment concerns in statutes restricting the use of the mails, simply ignored free speech issues in some cases, and held that certain categories of expression did not constitute "speech." On those relatively few occasions when it directly addressed the meaning of the First Amendment, the Court uniformly upheld restrictions on speech. Only a few opinions contained signs of a more generous interpretation of the value of free speech and the scope of the First Amendment.

\section{Avoiding First Amendment Issues}

A number of cases during the generation before World War One gave the Supreme Court opportunities to confront free speech issues. By a variety of methods, the Court usually avoided addressing the content and meaning of the First Amendment.

Resisting Incorporation into the Fourteenth Amendment. By declining until 1925 to hold that the Fourteenth Amendment incorporated First Amendment prohibitions, the Supreme Court limited the availability of federal courts to consider free speech claims. ${ }^{29}$ In 1875, the Court quickly thwarted the potential of an earlier circuit court decision ${ }^{30}$ by holding, in United States v. Cruikshank, that the Fourteenth Amendment did not empower Congress to legislate against infringements of free speech and assembly by private citizens. ${ }^{31}$ Cruikshank left open the possibility that the Fourteenth Amendment protected First Amendment freedoms against state action, ${ }^{32}$ but the Court

29. Beginning with its identification of liberty of contract in Allgeyer v. Louisiana, 165 U.S. 578, 589 (1897), the Court expanded the meaning of the liberty clause of the Fourteenth Amendment to declare social legislation unconstitutional. But not until Gitlow v. New York, 268 U.S. 652, 666 (1925), did the Court hold that freedom of speech and freedom of the press are protected by this clause. See Warren, The New "Liberly" Under the Fourteenth Amendment, 39 Harv. L. REv. 431 (1926).

30. United States v. Hall, 26 F. Cas. 79 (C.C.S.D. Ala. 1871) (No. 15,282), sustained the indictments, under the federal Enforcement Act of 1870 , of a mob of whites for unlawfully conspiring against a political meeting of black Republicans with intent to violate their rights of free speech and assembly. Judge Woods, who was later appointed to the Supreme Court, held that the Fourteenth Amendment extended First Amendment protections against states and empowered Congress to legislate if states failed to protect these rights against abridgment even by private parties. Id. at 81 .

31. 92 U.S. 542 (1875). Cruikshank, which also involved indictments under the Enforcement Act, was decided before any court cited Hall approvingly. The Court held that the enactment of the Fourteenth Amendment did not surrender to Congress the police power the Constitution had reserved to the states, $i d$. at 552 , and therefore added "nothing to the rights of one citizen as against another," id. at 554.

32. Id. at 554. The Court asserted that the Fourteenth Amendment prevented "an encroachment by the States upon the fundamental rights which belong to every citizen as a member of society," without identifying whether the contents of the First Amendment were fundamental. It suggested that citizens have a constitutional right, perhaps pro- 
did not take advantage of subsequent opportunities to resolve this question before World War One.

In 1887, the Court found that no federal questions were raised by the convictions of anarchists found guilty of aiding and abetting. murder because a fatal bomb exploded in Haymarket Square while they were advocating anarchist doctrine and distributing literature. ${ }^{33}$ As a result, it did not address the anarchists' contentions that the Fourteenth Amendment incorporated the entire Bill of Rights and that their convictions unconstitutionally deprived them of free speech. ${ }^{34}$ Twenty years later, Justice Holmes' majority opinion in Patterson $v$. Colorado sustained the contempt conviction of a newspaper editor, but expressly left "undecided the question whether there is to be found in the Fourteenth Amendment a prohibition similar to that in the First." 35 These decisions probably discouraged potential litigants from raising free speech claims in the federal courts, and most likely induced counsel in some cases to frame what were actually free speech issues in terms of the Fourteenth Amendment and other constitutional guarantees. ${ }^{36}$

Excluding Publications from the Mails. In a series of cases sanctioning the exclusion of publications from the federal mails, ${ }^{37}$ the Supreme Court examined the First Amendment somewhat more closely. Yet this closer look did not produce protective results. Using the rationale that Congress has no power to prevent the private circulation of publications, the Court sustained federal control of the postal power against challenges based on the First Amendment.

In Ex parte Jackson, ${ }^{38}$ the Court upheld the constitutionality of a federal statute that prohibited the mailing of lottery advertisements. Justice Field's majority opinion acknowledged that Congress, in exercising its power "to establish post-offices and post-roads," may not

tected even against private abridgment, to assemble to petition Congress about matters "connected with the powers or the duties of the national government," id. at 552, but stated that freedom to participate in a "meeting for any lawful purpose whatever" did not qualify for the same protection, $i d$. at $\mathbf{5 5 3}$.

33. Spies v. Illinois, 123 U.S. 131 (1887), aff'g Spies v. People, 122 Ill. 1, 12 N.E. 865 (1867). The anarchists claimed that they had been punished for "mere general advice" intended to change the existing order of society. 123 U.S. at 139.

34. 123 U.S. at 166 .

35. 205 U.S. 454,462 (1907). Dissenting, Justice Harlan contended that freedom of speech and press were protected as privileges and immunities of citizens of the United States and as liberties under the due process clause. Id. at 464-65.

36. See, e.g., pp. 530-31, 534-35, 538,542 \& note 91 infra (discussing briefs in Supreme Court cases).

37. See generally J. Paul \& M. Schwartz, Federal Censorship $31-37$ (1961).

38. 96 U.S. 727 (1877). 
"interfere in any manner with the freedom of the press." 39 It also recognized that liberty of publication has no value without liberty of circulation; if Congress could block all avenues of communication, freedom of the press would suffer a "fatal blow." Yet Congress, the opinion reasoned, has no power to prevent the circulation, through private channels, of matter it excludes from the federal mails. ${ }^{40}$ Denying lotteries and obscene material access to the mails, it asserted, is therefore not an unconstitutional interference with freedom of the press, but rather a legitimate refusal by Congress to use "its facilities for the distribution of matter deemed injurious to the public morals." 41 The Court did not discuss the viability of alternative means of circulation.

In a subsequent case, In re Rapier, ${ }^{42}$ brought against newspapers containing lottery advertisements, counsel for the petitioner warned that the rationale used in Ex parte Jackson would permit Congress to act as "official censor of public morals." 43 A political party in control of government, counsel argued, could "resolve to silence the journals of its adversaries" by enacting a law "that ... all utterances which dispute its tenets and policy are hostile to the public interests and morals," and therefore should be excluded from the mails. ${ }^{44}$ The Court's decision, however, essentially reiterated the prior discussion in Ex parte Jackson..$^{45}$ In an elliptical response to counsel's argument, Chief Justice Fuller concluded his opinion by stating that the danger of abuse of power "furnishes no grounds for a denial of its existence, if government is to be maintained at all." ${ }^{40}$ Ex parte Jackson, In re Rapier, and subsequent cases $^{47}$ thus gave judicial approval

39. Id. at 732-33.

40. Id. at 735 .

41. Id. at 736. In dicta, the Court specifically approved the Comstock Act, ch. 258, $\$ 2,17$ Stat. 598 (1873) (current version at 18 U.S.C. $\$ 1461$ (1976)), which excluded from the federal mails all publications of an "obscene" or otherwise "indecent character." 'The Comstock Act did not itself define obscenity. Cf. United States v. Reidel, 402 U.S. 351 (1971) (upholding constitutionality of contemporary codification of Comstock Act). See gencrally J. PAuL \& M. Schwartz, supra note 37, at 17-24, 27-28, 252-62; Paul, The Post Office and Non-Mailability of Obscenity: An Historical Note, 8 U.C.L.A. L. REv. 44 (1961).

12. 143 U.S. 110 (1892).

43. Argument of Hannis Taylor upon a Petition for Writs of Habeas Corpus and Certiorari at 48 .

44. Id. at 49 .

45. 143 U.S. at $133-35$.

46. Id. at 135. The government's brief, after referring to petitioner's warning that the postal power might be extended to exclude from the mails newspapers espousing specified political opinions, used language very similar to the quoted phrase of Fuller. Additional Brief of Assistant Attorney-General Maury at 15 .

47. See, e.g., Public Clearing House r. Coyne, 194 U.S. 497 (1904). In Coyne, the Court further expanded governmental control over the mails by upholding the con- 
to federal censorship over the mails. Legislation initially excluded lotteries and obscene material, but in 1917 the Espionage Act added treasonable and seditious language to the list of prohibited subject matter. ${ }^{48}$

Lewis Publishing Co. v. Morgan ${ }^{49}$ presented the Court with related issues. Congress historically had provided lower postal rates to newspapers and magazines in order to encourage " 'the dissemination of current intelligence." "זo As a condition for these rates, a 1912 statute required newspapers and magazines to label paid advertisements and to furnish information regarding ownership, managerial and editorial personnel, and circulation. ${ }^{51}$ Appellants attacked this statute as unconstitutional on First Amendment grounds. They claimed that the First Amendment prohibits all restrictions on the press "either by anticipation through a licensing system or retrospectively by obstruction or punishment," except in matters of "recognized morality" and common-law libel.52 If the Court upheld this statute, one of the briefs asserted, Congress could also deny mailing privileges or impose severe penalties "with respect to any newspapers owned or financially influenced by individuals advocating certain public questions or the policies of political parties." ${ }^{33}$ The Court rejected the publishers'

stitutionality of the Postmaster General's statutory authority to refuse to deliver all mail addressed to a company conducting a business that he considered to be a lottery or a fraud. Id. at 506-11. Neither the appellant nor the Court discussed any First Amendment questions.

48. Act of June 15, 1917, ch. 30, tit. 12, $\$ \$ 1,2,40$ Stat. 217 (current version at 18 U.S.C. $\$ 1717$ (1976) (prohibiting mailing of "matter advocating or urging treason, insurrection, or forcible resistance" to any federal law)).

49. 229 U.S. 288 (1913).

50. Id. at 302 (quoting report of Commission on Second-Class Mail Matter). At the time of the Lewis Publishing Co. litigation, the rate for letters was eighty times higher than the rate for newspapers; the profits from letter mail subsidized the losses from newspapers. Id. at 304. Previous cases had upheld decisions by the Postmaster General refusing to classify material as newspapers or magazines. See Bates \& Guild Co. v. Payne, 194 U.S. 106 (1904); Houghton v. Payne, 194 U.S. 88 (1904). But see 194 U.S. at 110 (Harlan, J., dissenting, joined by Fuller, C.J.); 194 U.S. at 100 (same).

51. Act of Aug. 24, 1912, ch. 389, $\S 2,37$ Stat. 539.

52. 229 U.S. at 292; see Brief for Appellant, Lewis Publishing Company, at $32-36$ [hereinafter cited as Brief for Appellant]. The publishing company also argued that the statute was designed to regulate journalism rather than to supervise the mails and therefore could not be sustained under the postal power. 229 U.S. at 298; see Brief for Appellant, supra, at 23.

53. Brief of Counsel for Appellant, The Journal of Commerce and Commercial Bulletin, at 38-39, Journal of Commerce \& Commercial Bulletin v. Burleson, 229 U.S. 288 (1913) (brief submitted in case consolidated with Lewis Publishing Co.). Although the brief writer assumed that "no one would attempt to uphold the right of Congress to so legislate," id. at 39, the Solicitor General proved him wrong. The government's brief maintained that if views held by the owner, including political theories, "are expressed in the paper Congress can doubtless exclude them, just as Congress could now exclude 
arguments against the statute. ${ }^{54}$ It held that the same interest in "the dissemination of knowledge of current events" that had prompted Congress to establish lower rates for second-class mail also justified the new requirements. ${ }^{55}$ The Court emphasized that its decision did not involve "any general regulation of what should be published in newspapers" or any absolute exclusion from the mails, but only the conditions for a publisher "to continue to enjoy great privileges and advantages at the public expense." 56

Later decisions under the Espionage Act, however, substantiated the concern that Congress might deny lower rates to punish newspapers publishing unpopular political views. Postmaster General Burleson revoked the second-class rates for the Milwaukee Leader in 1917 because, in his opinion, strongly antiwar articles in that newspaper violated the recently passed Espionage Act. In United States ex rel. Milwaukee Social Democratic Publishing Co. v. Burleson, ${ }^{57}$ the Supreme Court upheld his action, provoking a lengthy dissent by Justice Brandeis and a separate dissent by Justice Holmes. ${ }^{58}$ The Milwaukee Leader case incorporated Lewis Publishing Co. into the line of decisions, inaugurated by Ex parte Jackson, that used the content of a publication as the basis for restricting access to the federal mails.

Neglecting First Amendment Issues. In other cases, the Supreme Court did not even discuss free speech issues that the modern judge would clearly identify. In Davis v. Massachusetts, for example, the

all papers advocating lotteries, prohibition, anarchy, or a protective tariff if a majority of Congress thought such views against public policy." Brief for the United States at 46-47, Lewis Publishing Co. v. Morgan, 229 U.S. 288 (1913).

54. The statute's disclosure requirements remain in force today. See 39 U.S.C. $\$ 3685$ (1976).

55. 229 U.S. at 315-16. The statutory requirements, the Court pointed out, would disclose the financial interests that might influence the reporting of news. Because the low postal rates gave newspapers an "influence unequaled in history," the public has the right to know this information. Id. at 312 .

56. Id. at 316. The Court concluded its opinion by making clear that "we do not wish even by the remotest implication to be regarded as assenting to the broad contentions concerning the existence of arbitrary power through the classification of the mails, or by way of condition embodied in the proposition of the Government." Id.; see note 53 supra (quoting government contention to which Court apparently referred).

57. 255 U.S. 407 (1921).

58. Id. at 417-36 (Brandeis, J., dissenting); id. at 436-38 (Holmes, J., dissenting). In his dissent, Brandeis cited the Solicitor General's brief in Lewis Publishing Co. as an illustration of "[h]ow dangerous to liberty of the press would be the holding that the second-class mail service is merely a privilege, which Congress may deny to those whose views it deems to be against public policy." Id. at 431-32. Quoting the concluding remarks in Lewis Publisling Co., see note 56 supra, Brandeis suggested that the Court had not adopted the Solicitor General's view. 255 U.S. at 432 n.l; cf. Hannegan v. Esquire, Inc., 327 U.S. 146, 157 (1946) (Postmaster General may not require positive contribution to "public good or public welfare" for literature or art to qualify for second-class rates). 
Court upheld a Boston city ordinance that prohibited public addresses "in or upon any of the public grounds . . . except in accordance with a permit from the mayor." 59 Davis, a minister, asserted that the ordinance established an unjustified censorship and "violate[d] the rights of free public speech, of free assembly, and of free public religious worship." $60 \mathrm{He}$ also objected to the mayor's "Pontifical and Princely Power to Dispense with the prohibition." $61 \mathrm{He}$ alleged that the municipal authorities, contrary to the Fourteenth Amendment, enforced the ordinance solely against preachers of the gospel and ignored the many other men in public life who had given speeches on the common without obtaining a permit. ${ }^{62}$ The Supreme Court sustained the ordinance without addressing Davis' First Amendment or equal protection claims. "For the legislature absolutely or conditionally to forbid public speaking in a highway or public park," the Court reasoned in language taken verbatim from Justice Holmes' opinion below, "is no more an infringement of the rights of a member of the public than for the owner of a private house to forbid it in his house." 63 The Court also decided that the mayor's power to exclude anyone from public grounds necessarily included the lesser power to issue permits for their use. ${ }^{64}$

59. 167 U.S. 43,44 (1897).

60. Brief of James F. Pickering, for Plaintiff in Error, at 4, Davis v. Massachusetts, 167 U.S. 43 (1897) [hereinafter cited as Brief for Plaintiff in Error]. The brief claimcd that the city's purported justifications, the dangers of breaches of the peace and damage to the public grounds, were "most improbable and never threatened." Id. at 45. The Attorney General of Massachusetts responded by maintaining that the First Amendment protects "freedom as to substance, rather than as to place." Brief of Defendant in Error at 10 .

61. Brief for Plaintiff in Error, supra note 60, at 45 .

62. Id. at 19. Davis' counsel cited Yick Wo v. Hopkins, 118 U.S. 356 (1886), and other cases protecting Chinese immigrants from discriminatory municipal ordinances. Brief for Plaintiff in Error, supra note 60 , at $48-52$. He argued that as an American citizen and a preacher of the gospel, he deserved the same equal protection as alien Chinese. Id. at 50 . Davis' counsel also cited cases permitting parades by the Salvation Army to support his equal protection claim. Id. at 55-61.

63. 167 U.S. at 47 (citing Commonwealth v. Davis, 162 Mass. 510, 51I, 39 N.E. 113, 113 (1895)). Justice Holmes' famous epigram in McAuliffe v. Mayor of New Bedford, 155 Mass. 216, 220, 29 N.E. 517,517 (1892), foreshadowed his decision in Davis and was another example of the low priority he generally gave speech. Upholding the dismissal of a police officer for violating a regulation forbidding solicitation of money for political purposes, Holmes stated, "The petitioner may have a constitutional right to talk politics, but he has no constitutional right to be a policeman." See Van Alstyne, The Demise of the Right-Privilege Distinction in Constitutional Law, 81 HARv. L. REv. 1439, $1439-40$ (1968).

64. 167 U.S. at 48. But cf. Hague v. C.I.O., 307 U.S. 496, 514-16 (1939) (opinion of Roberts, J.) (invalidating municipal ordinances abridging right to use streets and parks to discuss and to distribute leaflets about public issues; Davis $v$. Massachusetts not controlling); id. at 533 (Butler, J., dissenting) (relying on Davis). 
In Ex parte Curtis, ${ }^{65}$ the Supreme Court also neglected First Amendment claims when it upheld the constitutionality of a statute forbidding employees of the United States to solicit or receive from each other money or property for political purposes. The petitioner protested that the statute, "under the banner of 'reform!'," gave a "deadly stroke" to freedom of expression. "[F]reedom of speech and of the press is abridged," he contended, "if every citizen cannot, at will, contribute to cause the speech to be made, in a suitable place; and, when made, that it may be disseminated, to accomplish the 'political purpose' for which it is intended." He could not imagine a "more severe blow at free discussion." 66 The majority of the Court, however, had no such difficulty. It viewed the statute simply as a constitutionally legitimate means to the valid legislative ends of promoting efficiency, integrity, and discipline among public servants..$^{67}$

In other cases that today would be recognized as raising First Amendment issues, counsel also ignored potential free speech claims. For example, in Halter $v$. Nebraska $a^{68}$ the Supreme Court sustained a Nebraska statute that prohibited the use of the United States flag in advertisements but not in newspapers or magazines. The defendants attacked this statute on a variety of constitutional grounds, but neither their brief nor the Court's opinion mentioned freedom of speech or "commercial" speech. ${ }^{69}$ Similarly, in Rosen v. United States, ${ }^{70}$ which affirmed a conviction for mailing obscene literature, the appellant and the Court focused on the specificity of the indictment under the Sixth Amendment without examining the standard applied by the lower court to define obscenity. ${ }^{71}$

Limiting the Meaning of Speech. At times, the Supreme Court considered free speech claims only to deny that the alleged constitutional violations involved speech. In Gompers v. Bucks Stove o Range

65. 106 U.S. 371 (1882); see Act of Aug. 15, 1876, ch. 287, $\S 6$, I9 Stat. 143 (current version at 18 U.S.C. $\$ \$ 602.603$ (Supp. III 1979) (forbidding government employees to solicit political contributions from colleagues or to make contributions to employers)).

66. Brief for the Petitioner at 28-29. The government's brief dismissed this claim as "not . . . worthy of very serious attention." Brief for the Government at 12.

67. 106 U.S. at 373; cf. note 198 infra (citing cases upholding restrictions on political activity by federal employees).

68. 205 U.S. 34 (1907).

69. Among other arguments, the defendants maintained that the statute deprived them of property without due process, Brief for Plaintiffs in Error at 49-55, and denied them equal protection by regulating only advertisements, id. at 55-59. For Justice Harlan's rejection of these contentions, see 205 U.S. at $42-46$. But see note 272 infra (discussing cases holding "commercial speech" protected by First Amendment).

70. 161 U.S. 29 (1896).

71. Id. at $42-43$ (discussing roles of jury and judge in determining whether material is obscene under Hicklin test, see p. 548 infra, without reference to freedom of expression). 
Co., ${ }^{72}$ the president of the American Federation of Labor asserted that an injunction was unconstitutional because it ordered the union not to publish or otherwise state that the company was on the union's "Unfair" and "We don't patronize" lists. ${ }^{73}$ Conceding that a legislature could punish the publication at issue, Gompers denied that courts of equity had authority to impose by injunction a prior restraint on speech. ${ }^{74}$ The Court refused to discuss the First Amendment question, holding without explanation that "the general provisions of the injunction did not, in terms, restrain any form of publication." 75 The opinion went on to imply a distinction between normal speech, which is protected by the First Amendment, and "verbal acts," which have "a force not inhering in the words themselves," and which are "as much subject to injunction as the use of any other force whereby property is unlawfully damaged." When speech becomes a means for accomplishing an unlawful purpose-in Gompers, a union boycott conspiring in restraint of trade-it is no longer speech but a "verbal act." 70 This distinction, which foreshadowed modern debate over the alleged distinction between speech and conduct, ${ }^{77}$ probably explains why the Court did not consider the injunction a forbidden prior restraint. The First Amendment prohibits only prior restraints upon speech and, under the Court's analysis, "verbal acts" are apparently a form of conduct.

The Court limited the meaning of speech in a different context in Mutual Film Corp. v. Industrial Commission of Ohio. ${ }^{78}$ The appellants attacked, as a prior restraint in violation of the free speech provision of the Ohio Constitution, a state law that required approval of all films by a board of censors before exhibition. The briefs of both parties, atypically for this period, concentrated on free speech

72. 221 U.S. 418 (1911).

73. Id. at $420 \mathrm{n} .1$ (text of injunction).

74. Brief for Appellants at 12-13, 26. Gompers cited Justice Holmes' decision in Patterson v. Colorado, 205 U.S. 454 (1907), see Pp. 533-34 infra, to support his claim that the injunction was an unconstitutional prior restraint on publication. Supplemental and Reply Brief for Appellants at 18.

75. 221 U.S. at $436-37$.

76. Id. at 439 .

77. See, e.g., Konigsberg v. State Bar, 366 U.S. 36, 64 (1961) (Black, J., dissenting); Giboney v. Empire Storage \& Ice Co., 336 U.S. 490, 498 (1949); Chaplinsky v. New Hampshire, 315 U.S. 568, 572-74 (1942); T. Emerson, Toward a General Theory of the First Amendment 60.61 (1966); A. Meiklejohn, Free Speech ANd Its Relation to Self-GovERNMENT 42.43 (1948).

78. 236 U.S. 230 (1915). The Court's jurisdiction apparently derived from appellants' claim that the state statute "imposes an unlawful burden on interstate commerce," id. at 239 , a claim the Court quickly rejected, $i d$. at $240-41$. 


\section{Prewar Free Speech}

arguments. ${ }^{79}$ The brief of the Ohio Attorney General is especially revealing because it recognized the potential First Amendment concerns lurking in prior Supreme Court cases decided on other grounds. ${ }^{80}$ The Supreme Court began with generalities about the certainty, value, and breadth of "freedom of opinion and its expression," asserting "that opinion is free and that conduct alone is amenable to the law." "s1 But after invoking these pieties, the Court promptly rejected the appellants' argument that films are "publications of ideas" deserving the same constitutional protection as other publications. The Court found this position inconsistent with "common sense" and "judicial sense."s2 According to the Court, the exhibition of films was simply a profitmaking business and should not be regarded "as part of the press of the country or as organs of public opinion."

\section{Addressing First Amendment Issues}

In a number of cases brought in the generation before Schenck, the Supreme Court found itself confronted with First Amendment claims that could not be avoided so easily. The Court underlined its insensitivity to the value of free speech by uniformly rejecting all of them. The decisions stated or assumed that speech could be penalized if it had a "bad tendency" upon the public welfare.

Justice Holmes and the Bad Tendency of Speech. Two of Justice Holmes' opinions before Schenck focused explicitly on the supposed "bad tendency" of speech. In Patterson v. Colorado, ${ }^{84}$ he upheld a contempt conviction for criticizing judicial behavior, without affording the offending editor an opportunity to prove truth as a defense. The First Amendment, Holmes declared, prevents all "previous restraints upon publications," but allows "the subsequent punishment of such as may be deemed contrary to the public welfare .... The

79. Brief of Appellants, Mutual Film Corporation and The Mutual Film Company, at 11-62, Mutual Film Corp. v. Industrial Comm'n of Ohio, 236 U.S. 230 (1915) [hereinafter cited as Brief of Appellants]; Brief of Appellees at 16-32, Mutual Film Corp. v. Industrial Comm'n of Ohio, 236 U.S. 230 (1915) [hereinafter cited as Brief of Appellees].

80. Citing Gompers v. Bucks Stove \& Range Co., 221 U.S. 418 (1911), and two cases prohibiting the use of the mails for lotteries, In re Rapier, 143 U.S. 110 (1892); En parte Jackson, 96 U.S. 727 (1877), the brief asserted that these cases would necessarily have considered free specch issues "if such liberties are as broad as claimed by the appellants in this case." Brief of Appellees, supra note 79, at 25; see id. at 25-28.

81. 236 U.S. at 243 (quoting unidentified source).

82. Id. at $243,244$.

83. Id. at 244. But see Joseph Burstyn, Inc. v. Wilson, 343 U.S. 495, 50I-02 (1952) (motion pictures are "significant medium for the communication of ideas"; Mutual Film disapproved).

84. 205 U.S. 454 (1907). 
preliminary freedom extends as well to the false as to the true; the subsequent punishment may extend as well to the true as to the false."si Holmes believed that this rule, developed in the context of the common law of criminal libel and summarized by Blackstone, ${ }^{86}$ is particularly applicable to contempts of court. Publications criticizing judicial behavior in pending cases, he pointed out, "tend to obstruct the administration of justice," whether or not the allegations are true. ${ }^{87}$

Fox v. Washington, ${ }^{88}$ decided eight years after Patterson, gave Holmes another opportunity to consider the relationship between the bad tendency of speech and crime. Fox challenged the constitutionality of a Washington statute that made it a gross misdemeanor to publish, edit, or circulate written matter "in any form, advocating, encouraging or inciting, or having a tendency to encourage or incite the commission of any crime, breach of the peace or act of violence, or which shall tend to encourage or advocate disrespect for law or for any court or courts of justice." 89 The plaintiff in error was convicted under this statute for editing an article entitled "The Nude and the Prudes," which predicted and encouraged a "boycott" against those who interfered with nude bathing in the community. ${ }^{90}$

Gilbert Roe's brief attempted to distinguish Fox from the many cases upholding statutes that punished "language naturally tending to produce" crimes such as breach of the peace and assault and battery, and from cases sustaining statutes that prohibited sending ob-

85. Id. at 462. Holmes assumed for purposes of argument that the Fourteenth Amendment might incorporate First Amendment prohibitions. See p. 526 supra.

86. In the section of his Commentaries cited by Holmes, 205 U.S. at 462, Blackstone defined criminal libels as writings "of an immoral or illegal tendency" and considered them a subcategory of crimes, such as "challenges to fight," that tend to provoke breaches of the peace. Thus, "the provocation, and not the falsity, is the thing to be punished criminally." 4 W. BLAckstone, Commentaries *150. Blackstone went on to discuss previous restraints. Id. at *151-52, quoted in note 299 infra. Although Holmes also relied on those sections, see pp. 533-34 supra, he did not include them in his reference to Blackstone. Holmes added citations to Commonwealth v. Blanding, 20 Mass. (3 Pick.) 304 (1826), and Respublica v. Oswald, I Dall. 319 (Pa. 1788), two early state libel cases that followed Blackstone.

87 . 205 U.S. at 462 . Holmes added that the definition of contempt was a matter of local law for the state court to decide as long as there was no showing that "innocent conduct has been laid hold of as an arbitrary pretense for an arbitrary punishment." Id. at 461 .

Patterson has been cited to support the proposition that the First Amendment provides greater protection against prior restraints than against subsequent punishments. See Nebraska Press Ass'n v. Stuart, 427 U.S. 539, 557 (1976); Near v. Minnesota, 283 U.S. 697,714 (1931).

88. 236 U.S. $273(1915)$.

89. Id. at 275-76.

90. Id. at 276-77. 
scenity through the mails. In all these situations, Roe maintained, " $[t]$ he character and causes of the prohibited act are known, and it is possible to determine with some degree of certainty, what language induces the commission of such act." In Fox, by contrast, "the mental state of the reader or hearer described as 'disrespect for law' is the ultimate fact to be produced by the use of the language penalized, and who can say what language will produce that state of mind?" 01

Holmes wrote the opinion sustaining Fox's conviction. He stressed that the decision of the Court had "nothing to do with the wisdom of the defendant, the prosecution, or the act. All that concerns us is that it cannot be said to infringe the Constitution of the United States." With evident discomfort and without really responding to Roe's argument, Holmes strained to limit a statute he did not like. He rejected the argument that the act was "an unjustifiable restriction of liberty and too vague for a criminal law." Holmes contended that, "by implication at least," the state court had "read the statute

91. Brief for Plaintiff-in-Error at 15, Fox v. Washington, 236 U.S. 273 (1915) [hereinafter cited as Brief for Plaintiff-in-Error]. Roe's brief concentrated on demonstrating the vagueness of the statute, a theme stressed in Theodore Schroeder's writings, see p. 577 \& note 346 infra, and also alleged that the statute deprived Fox of the liberty protected by the Fourteenth Amendment. Brief for Plaintiff-in-Error, supra, at 15-17. Roe referred to the First Amendment only in two sentences at the end of his brief. He reminded the Court that Patterson $v$. Colorado raised, but did not decide, the issue of whether the Fourteenth Amendment applied the First Amendment to state action, and pointed out that the record in Fox preserved that question. $I d$. at 17 . He concluded the brief simply by reiterating his view that the Fourteenth Amendment alone was sufficient to reverse Fox's conviction. Id.

It is somewhat surprising that Roe, a major figure in the Free Speech League, did not use this opportunity to raise First Amendment claims, especially because he viewed this case, among the many that came to his attention, as a particularly promising vehicle for a useful decision from the Supreme Court. Letter from Gilbert E. Roe to Theodore Schroeder (Dec. 31, 1912) (Theodore Schroeder Papers, Box 10, Southern Illinois University Library). Roe might have rationally concluded, based on the Court's prior decisions, that it would be unsympathetic to First Amendment claims. Yet Holmes in Patterson had produced one of the Court's few prewar holdings on the meaning of the First Amendment. Holmes might also have addressed First Amendment claims in Fox if Roe had presented them. And even if Holmes' reactions to the libertarian views of Roe and the Free Speech League had been as unresponsive to the value of free speech as his opinion in Patterson, Fox, like Patterson, might have provoked a substantive dissent.

92. 236 U.S. at 278 . Whatever his views on the merits of a law, Holmes generally upheld legislation against constitutional attacks. This approach accounts in large part for his dissents in substantive due process cases and for his misleading reputation as a liberal. In Lochner v. New York, 198 U.S. 45 (1905), a case that applied "liberty of contract" to invalidate a state statute limiting working hours, Holmes also denied that his personal views on the merits of legislation had constitutional significance. Id. at 75 (Holmes, J., dissenting). Holmes noted in Lachner that the Post Office, among other institutions, interferes with the liberty of the citizen. $I d$. Gilmore and Rogat have stressed the deference Holmes gave to dominant political majorities. See G. Gramore, supra note 25, at 48-50, 66-67, 131 n.36; Rogat, The Judge as Spectator, 31 U. CHI. L. REv. 213, 253-55 (1964). 
as confined to encouraging an actual breach of law." ${ }^{93} \mathrm{He}$ found it unlikely that the statute would be "construed to prevent publications merely because they tend to produce unfavorable opinions of a particular statute or of law in general." 94

In Fox, "the disrespect for law that was encouraged was disregard of it-an overt breach and technically criminal act." fensive article, Holmes found, "by indirection but unmistakably . . . encourages and incites a persistence in what we must assume would be a breach of the state laws against indecent exposure." 96 He noted that even without statutory prohibitions such statements, "if directed to a particular person's conduct, generally would make him who uttered them guilty of a misdemeanor if not an accomplice or a principal in the crime encouraged." Holmes acknowledged that Fox's article was directed to "a wider and less selected audience," but he added, as if to dispose of this problem, that "[1]aws of this description are not unfamiliar." 97

Review of Statutes Penalizing Speech. During this period, the Court also upheld convictions under two other statutes that directly penalized speech. Although neither statute imposed prior restraints or criminal penalties, both restricted individual rights as a result of prohibited advocacy. The Court in these cases also seemed to apply the bad tendency rationale.

In Turner $v$. Williams, ${ }^{98}$ an anarchist who was. a British alien challenged his pending deportation under the Alien Immigration Act of 1903, which excluded "anarchists, or persons who believe in or advocate the overthrow by force or violence of the Government of the United States or of all government or of all forms of law, or

93. 236 U.S. at 277 . "It would be in accord with the usages of English," he reasoned, "to interpret disrespect as manifested disrespect, as active disregard going beyond the line drawn by the law." Id.

94. Id.

95. Id.

96. Id.

97. Id. at 277-78. But cf. Brandenburg v. Ohio, 395 U.S. 444, 447 (1969) (state may not "forbid or proscribe advocacy of the use of force or of law violation except where such advocacy is directed to inciting or producing imminent lawless action and is likely to incite or produce such action"); Wechsler, Jones, \& Korn, The Treatment of Inchoate Crimes in the Model Penal Code of the American Law Institute: Attempt, Solicitation, and Conspiracy, 61 CoLuM. L. REv. 571, 626-27 (1961) (to prevent legitimate agitation from being misinterpreted as solicitation to crime, Model Penal Code, though apparently not First Amendment, requires solicited conduct to be "specific"); $i d$. at 622 n.295 (citing several cases decided in generation before World War I that addressed relationship between speech and crime).

98. 194 U.S. 279 (1904). 


\section{Prewar Free Speech}

the assassination of public officials." 00 Turner was arrested following a lecture in New York City, during which he had predicted a general strike throughout the industrial world, discussed its probable local effects, and stated that, "as an anarchist, as one who believes that the people should emancipate themselves, I look forward to this struggle as an opportunity for the workers to assert the power that is really theirs." This lecture, and a list of proposed lecture topics found on Turner when he was arrested, constituted the evidence that formed the basis for his pending deportation. .00 $^{10}$

In their brief for Turner, financed by the Free Speech League, ${ }^{101}$ Clarence Darrow and Edgar Lee Masters stressed that "[a]narchists are distinguished by a definite creed and not by the means proposed to propagate the creed or render it paramount." They argued that anarchists do not necessarily believe in or advocate the overthrow of government by force or violence and therefore are not, solely by definition, guilty of violating the act. ${ }^{102}$ Darrow and Masters also pointed out that no evidence against Turner indicated that he personally urged the use of force or violence. ${ }^{103}$ To deport him, they concluded, would violate the First Amendment. At a more general level, Darrow and Masters asserted that " $[t]$ he fundamental basis of free opinion demands that convictions shall be freely spoken to the end that the truth shall be known. Upon this freedom all progress depends." 104

These arguments did not convince the Supreme Court. The majority asserted that if Congress defined an anarchist as one who sup-

99. Act of March 3, 1903, ch. 1012, $\$ \S 2,38,32$ Stat. 1213 (current version at 8 U.S.C. $\$ \$ 1182(a)(28)(A)-(B),(F)-(G)(1976)$ (omitting direct reference to belief in anarchist doctrine)).

100. 194 U.S. at 283. His proposed lectures included "The essentials of anarchism" and "The legal murder of 1887." Id. The latter referred to the executions of the defendants in the Haymarket bombings. Id. at 294; see p. 526 supra.

101. See 1 E. Goldman, Living MY Life 348 (1931); Letter from E.B. Foote, Jr., to "Dear Sir" (March 5, 1904) (Theodore Schroeder Papers, Box 6, Southern Illinois University Library).

102. Brief and Argument of Appellant at 36 .

103. Id. at 6 .

104. Id. at 49 . The brief also cited Freund's treatise, id. at 47 ; see E. Freund, supra note 28 , at $509-10$; pp. $572-73$ infra. The government's brief, written by future Supreme Court Justice McReynolds, called Turner's First Amendment claims "incomprehensible." Brief for Appellee at 21. The brief's treatment of this issue reveals its general hostility to free speech, particularly for aliens. "Abridgment of the freedom of speech or of the press," it contended, "is no more brought about by the exclusion or expulsion of anarchists than by similar treatment of the followers of Confucius." The brief added that "the right to talk is no more sacred than the right to work" and pointed out that not all alien workers could be admitted. The statute, rather than violating the First Amendment, protected the country from aliens seeking to overthrow the government. Id. at 22. The Court did not refer to this portion of the government's brief. 
ports the violent overthrow of government, any alien "who avows himself to be an anarchist, without more," adopts that definition and is subject to deportation. ${ }^{105}$ In any event, the Court added, Turner's speech and proposed lecture topics justified the inferences that "he contemplated the ultimate realization of his ideal by the use of force" and that "his speeches were incitements to that end."10" According to the Court, moreover, there could be no constitutional objection to the Act even if it defined anarchists as "political philosophers innocent of evil intent," for Congress could legitimately conclude "that the tendency of the general exploitation of such views is so dangerous to the public weal that aliens who hold and advocate them would be undesirable additions to our population." The Court cautioned that in reaching this conclusion it should not "be understood as depreciating the vital importance of freedom of speech and of the press." This freedom, the Court felt, was not involved in Turner, apparently because "as long as human governments endure they cannot be denied the power of self-preservation."107

The Court faced related issues in Davis v. Beason, ${ }^{108}$ the appeal of a Mormon convicted for falsely taking an oath required by an Idaho territorial statute for registration as a county elector. The affiant had to swear that he was not a bigamist or polygamist, nor a member of any organization "which teaches, advises, counsels or encourages" bigamy or polygamy. ${ }^{109}$ Davis was convicted for signing the oath because the Mormon church taught bigamy and polygamy. ${ }^{110} \mathrm{His}$ attorneys argued that "[h]e did not practice bigamy or polygamy, nor did he advise anyone else to do so." While pointing out that the record gave no indication that Davis believed in these practices, his attorneys emphasized that even if he did, he could not be disenfranchised as a result. ${ }^{111}$ According to their brief,

[i]t is only when he has done an act that the law has declared to be criminal that he can be punished or deprived of any right common to his fellow-citizens, and then he is not punished, or thus deprived, because of his opinion but because of the commission of the act which has been forbidden by law. ${ }^{112}$

105. 194 U.S. at 293 .

106. Id. at 294 .

107. Id. The Court also denied that the debate over the constitutionality of the Alien and Sedition Acts of 1798 had "any bearing upon this case." Id. at 295.

108. 133 U.S. 333 (1890).

109. Id. at 334,335 n.l.

110. Id. at $334-35$.

111. Brief for Appellant at 14-15, Davis v. Beason, 133 U.S. 333 (1890).

112. Id. at 38 . The brief, $i d$. at 15 , sharply distinguished the facts of Reynolds v. 
This issue was framed and resolved under the free exercise clause of the First Amendment, but the Court included some significant dicta on the relationship between speech and crime. Rejecting the arguments in Davis' brief, the Court reasoned that advocating the crimes of bigamy or polygamy aids in their commission and could be punished as appropriately as any other case of aiding and abetting crime. ${ }^{113}$ The oath, the Court concluded, was designed "to prevent persons from being enabled by their votes to defeat the criminal laws of the country." 114 The Court proceeded to affirm Davis' conviction without citing any evidence that he actually taught, advised, or counseled commission of the forbidden acts. Notwithstanding the First Amendment, it seemed to assume that Davis' membership in the Mormon church, like Turner's belief in anarchy, was itself sufficient for conviction. The Court, as well as the statutes it upheld, took for granted the proposition that expressions of opinion can themselves be penalized for their bad tendency to lead to a socially undesirable act.

The First Amendment as the Embodiment of English Common Law. In the years before World War One, the Supreme Court also asserted that the First Amendment did not expand the protection that English common law had given free speech and press at the time the states ratified the Bill of Rights. In Robertson v. Baldwin, ${ }^{115}$ a case decided under the Thirteenth Amendment, the Court declared that the Bill of Rights did not set forth "any novel principles of government," but simply embodied "certain guaranties and immunities which we had inherited from our English ancestors, and which had from time immemorial been subject to certain well-recognized exceptions arising from the necessities of the case." The exceptions "continued to be recognized as if they had been formally expressed."116 To illustrate this point, the Court stated that free speech did not "permit the publication of libels, blasphemous or indecent articles,

United States, 98 U.S. 145 (1878) (affirming imprisonment and fine of Mormon who practiced bigamy). The Court in Reynolds, citing Thomas Jefferson, held that under the First Amendment "Congress was deprived of all legislative power over mere opinion, but was left free to reach actions which were in violation of social duties or subversive of good order." $I d$. at 164 .

113. 133 U.S. at 342; see p. 536 supra (Holmes in Fox identified speaker as "accomplice").

114. 133 U.S. at 348. Underlining its willingness to punish speech, the Court rejected Davis' contention that congressional legislation that prohibited bigamists and polygamists from voting in territorial elections preempted the power of the Idaho territorial government to require the oath. $I d$. at $347-48$. It reasoned that the territorial statute dealt with a different subject, because the "act of Congress does not touch upon teaching, advising, and counselling the practice of bigamy and polygamy." Id. at 348 .

115. 165 U.S. 275 (1897).

116. Id. at 281 . 
or other publications injurious to public morals or private reputation."117

United States v. Press Publishing Co. ${ }^{118}$ is consistent with the Robertson dicta. Press Publishing Company, which owned the New York World, had been indicted for publishing criminal libels against the President and the Secretary of War. The alleged libels consisted of six newspaper articles condemning the acquisition of the Panama Canal by the United States. Counsel for the publisher moved to quash the indictment on the ground that a trial would "abridge the liberty of speech and of the press" and create an atmosphere in which "no owner or editor of a paper could with safety freely discuss public affairs." 119 The Court used complicated jurisdictional arguments to avoid resolving the merits of the case. But by concluding that state law would provide "adequate means" for punishing the alleged libel, ${ }^{120}$ the Court hinted that it might find a conviction for criminal libel permissible under the federal Constitution as well. Thus, the Court suggested that the common-law crime of libel, possibly including seditious libel, survived the ratification of the First Amendment.

The Supreme Court, moreover, did not consider the exceptions to protected speech frozen by the common law in the late eighteenth century. Decisions like Davis v. Beason and Turner v. Williams demonstrate a willingness to punish "evils" unanticipated by the framers but deemed injurious to the public welfare by contemporary legislators and administrators.

\section{Hints of Protection}

Only a few, isolated opinions before World War One indicated that the First Amendment could be more than a paper guarantee. Several dissents and concurrences identified constitutionally protected speech. One majority decision, although not addressing First Amendment issues, did protect certain free speech values. None of these opinions, however, presented a coherent theory of First Amendment interpretation.

Justice Harlan's dissent in Patterson v. Colorado contained a vig-

117. Id.

118. 219 U.S. 1 (1911).

119. Id. at 7 (quoting Brief for the Defendant in Error at 11). The publisher argued that sustaining the indictment would give the federal government power "to prosecute any publisher who had attacked the government, or the character of government officials, by criticizing their public acts." Brief for the Defendant in Error at 23.

120. 219 U.S. at 15. The Court quashed the federal indictment because it found that the state court had jurisdiction. Id. at 15-16. 
orous, if undeveloped, defense of freedom of expression. He explicitly opposed Holmes' conclusion that the First Amendment prevents only prior restraints. He feared Holmes' view would allow a legislature to "impair or abridge the rights of a free press and of free speech whenever it thinks that the public welfare requires that to be done." According to Harlan, legislative determinations of the public welfare "cannot override constitutional privileges." $121 \mathrm{He}$ therefore concluded that the contempt conviction of the publisher was unconstitutional. Although Harlan did not elaborate his views on the First Amendment, his analysis in Patterson did provide a doctrinal alternative to the widespread practice of invoking the alleged bad tendency of speech as an automatic barrier against free speech claimants.

Justice Bradley's dissent in Ex parte Curtis also protested that the majority decision permitted an unconstitutional violation of First Amendment rights. Attacking the statutory prohibition against federal employees soliciting or receiving money from each other for political purposes, he claimed that "[n]either men's mouths nor their purses can be constitutionally tied up in that way." ${ }^{122}$ Bradley considered financial contributions to be among "the necessary and proper means for promoting political views" because they allow citizens "to aid discussion and to disseminate information and sound doctrine."123 $\mathrm{He}$ conceded that Congress had acted with the admirable intention of preventing political corruption, but contended that "in adopting this particular mode of restraining an acknowledged evil, Congress has overstepped its legitimate powers, and interfered with the substantial rights of the citizen." 124

In his concurrence in Turner v. Williams, Justice Brewer questioned the scope of the majority opinion by suggesting some limitations on the reach of the Alien Immigration Act. He agreed that it was "not an unreasonable deduction" from the record that Turner was "an anarchist in the commonly accepted sense of the term, one who urges and seeks the overthrow by force of all government." However, Brewer considered it unnecessary for the majority to extend the law to philosophical anarchists as well. ${ }^{125} \mathrm{His}$ concurrence is far from a ringing affirmation of First Amendment rights. Brewer did not even

121. 205 U.S. 454, 465 (1907) (Harlan, J., dissenting); cf. id. at 465-66 (Brewer, J., dissenting) (constitutional claim not frivolous and should therefore have been addressed by Court).

122. 106 U.S. 371, 377 (1882) (Bradley, J., dissenting).

123. Id. at 376 .

124. Id. at 378 .

125. 194 U.S. 279, 296 (1904) (Brewer, J., concurring). 
assert that it would be unconstitutional to deport philosophical anarchists. But at least he acknowledged that this issue presented a potential problem that the majority should not have addressed and resolved so facilely.

Finally, in at least one case, the Supreme Court overruled a Postmaster General's decision to confiscate mail. In American School of Magnetic Healing v. McAnnulty, ${ }^{126}$ the Court held that the Postmaster General acted unlawfully in refusing to deliver payments mailed to a business selling Christian Science treatments. Without reference to the First Amendment, ${ }^{127}$ the Court rejected the Postmaster General's determination that Christian Science is fraudulent by definition. Noting that "[e]ven intelligent people" differ as to the influence of the mind on the body, the Court reasoned that " $[t]$ here is no exact standard of absolute truth" by which to judge the claims of Christian Scientists. Since the statute dealing with fraudulent use of the mails was not directed at "mere matters of opinion upon subjects which are not capable of proof as to their falsity," the Court held that the Postmaster General was violating the law. ${ }^{128}$ Although the Court was not similarly solicitous of differences of opinion in more controversial settings, Magnetic Healing did indicate that there could be some limits to federal censorship of ideas. ${ }^{129}$

\section{Summary}

Despite these hints of protection, Supreme Court decisions in the generation before World War One reflected a tradition of pervasive hostility to the value of free speech. The Court rejected First Amendment claims whenever it confronted them directly. But confrontation, even in rejection, at least lent these claims some status. More frequently, in rendering decisions that today would be based on an analysis of the First Amendment, the Court did not address free speech issues at all. The Court repeatedly denied that cases implicated freedom of expression, and often made no reference to the First Amendment.

126. 187 U.S. 94 (1902).

127. The Statement and Brief In Behalf of Appellants at 43, unlike the briefs in In re Rapier and Lewis Publishing Co., did not raise First Amendment claims, although it alleged violations of the Fourth and Fifth Amendments. There is therefore considerable irony in the fact that Magnetic Healing was the only prewar decision by the Court in which a majority provided any potential protection to freedom of expression.

128. 187 U.S. at 104.

129. In his dissent in Pierce v. United States, 252 U.S. 239, 267 (1920), Justice Brandeis cited Magnetic Healing and applied its reasoning to criticisms of American participation in World War One. 


\section{B. Decisions Based on State Law}

Limiting attention to decisions by the United States Supreme Court may give a misleading impression of judicial tradition. This caveat applies with particular force to the prewar interpretation of freedom of expression, because the Court's strict construction of the Fourteenth Amendment imposed a major barrier to federal adjudication of First Amendment claims. Cases decided by other courts, which were generally based on state law, allow a fuller picture of the prewar judicial approach to free speech. State courts decided most of these cases, although some reached the federal courts, usually through diversity jurisdiction. Most of these decisions were as unresponsive to First Amendment values as their Supreme Court counterparts. But, perhaps simply as a consequence of a larger sample of judges, issues, and factual settings, the reasoning and outcome in a significant number of them provided more meaningful protection for freedom of expression than any decision produced by the Supreme Court. They demonstrate that the judicial tradition was not monolithic and that more libertarian values occasionally received court approval.

\section{The Bad Tendency Doctrine}

Free speech cases based on state law, like the few Supreme Court cases that addressed the meaning of the First Amendment, often referred to the supposed bad tendency of speech for doctrinal support. These cases arose in a variety of contexts, but most involved perceived threats to the public order by language considered radical or immoral.

Speech by Radicals. State courts punished speech by many radical leaders and groups, finding that it had a bad tendency to cause unrest in an impressionable public. New York's highest court twice affirmed convictions of Johann Most, a prominent radical editor. The first conviction, under a statute that prohibited assembling with others to attempt or threaten "any act tending towards a breach of the peace," was based on a speech Most delivered to a meeting of anarchists the day after the Haymarket defendants had been hanged in Chicago. ${ }^{130} \mathrm{He}$ urged his audience to "arm yourself, as the day of revolution is not far off; and when it comes, see that you are ready to resist and kill those hirelings of capitalists" who, in his opinion, were responsible for the executions. ${ }^{131}$ Most argued that his speech consisted of prophecies of what would be likely to happen, and not

130. People v. Most, 128 N.Y. 108, 109, 27 N.E. 970, 970 (1891).

131. Id. at 111,27 N.E. at 971 . 
threats that he or others in sympathy with him would commit violence or murder. ${ }^{132}$ The court concluded that the jury's conviction was based on sufficient evidence, ${ }^{133}$ reasoning that "[i]ncendiary speeches ... . before a crowd of ignorant, misguided men, are not less dangerous because ... [they] are accompanied with the suggestion that the time is not quite come for action." 134 Noting that the audience was sympathetic and highly excited, the court stressed that "[n]o one can foresee the consequences which may result from [such] language." 135 The court viewed this uncertainty, not as a consideration against punishing speech, but as an added reason to do so.

Eleven years later, the same court affirmed another conviction of Most, this time for endangering the public peace by republishing an article in his newspaper the day President McKinley was shot by an anarchist. ${ }^{136}$ The article argued that all government is founded on murder, and maintained that revolutionary forces sometimes have a duty to kill "a professional murderer." ${ }^{337}$ The court concluded that the article "manifestly tended toward" a breach of the public peace by using language that was "an invitation to murder"138 and could not be considered legitimate criticism of public affairs. ${ }^{130}$ Although the article neither addressed a specific person nor advocated the murder of any particular individual, the court observed that its readers would include "reckless and aggressive" persons "who are ready to act on such [general] advice, and to become the assassins of those whom the people have placed in authority." Such articles "naturally lead" to assassination, and their "punishment and repression are essential to the welfare of society and the safety of the state." 140 By invoking the familiar distinction between "free" speech and its "license" or "abuse," the court stressed that its holding was consistent with the provisions in the state constitution forbidding the abridgment of speech. ${ }^{141}$

132. Id. at 114-15, 27 N.E. at 972.

133. Id. at 114,27 N.E. at 972.

134. Id. at 115,27 N.E. at $972-73$.

135. Id. at 115-16, 27 N.E. at 973 .

136. People v. Most, 171 N.Y. 423,64 N.E. 175 (1902). Although the article had been written fifty years earlier by another author, id. at 425,64 N.E. at 176 , the court found that Most, by his introductory comment stating that the article "is true even to-day," had endorsed the sentiments and ratified the advice given, id. at 428, 64 N.E. at 177.

137. Id. at $426-27,64$ N.E. at 176 .

138. Id. at 430,64 N.E. at 178 .

139. Id. at 428,64 N.E. at 177.

140. Id. at 430,64 N.E. at 178; cf. Fox v. Washington, 236 U.S. 273, 277-78 (1915) (speech not directed at specific person may be punished if it encourages breach of laws); p. 536 supra (discussing lack of specificity of speech by Fox).

141. 171 N.Y. at 431,64 N.E. at 178 . The court, relying on treatises and precedents 


\section{Prewar Free Speech}

Emma Goldman confronted similar reasoning when she asked for an injunction to prevent officials in Philadelphia from denying a public hall for her lectures. A Pennsylvania state court, refusing to issue an injunction, rejected her argument that the officials violated the free speech clause of the state Constitution. ${ }^{142}$ If Goldman lectured, the court concluded, "dangerous and disturbing sentiments tending to disturb the peace would be uttered." Even worse, Goldman wanted to "advocate ideas which, if carried out, would naturally lead to the destruction of government." ${ }^{143}$ In words close to those of the Supreme Court in Turner v. Williams, the Pennsylvania court held that the government's "right of self-preservation" overrides "such abuse of the right of free speech." 144 The court closed its opinion, in a manner typical of the prewar period, by invoking the importance of free speech while denying its exercise. ${ }^{145}$

Cases arising from a strike in Paterson by the Industrial Workers of the World presented similar issues to the Supreme Court of New Jersey. The court upheld the convictions of speakers who had urged violence $^{14 b}$ and industrial sabotage. ${ }^{147}$ The statute under which these speakers were indicted made it a misdemeanor to "encourage," "incite," or "advocate" destruction of property or assaults on individuals. ${ }^{148}$ In sustaining the constitutionality of this statute, the court stressed that "[i]ncitement to the commission of a crime is a misdemeanor at common law, whether the crime advocated be actually committed or not."149 The court thus rejected Gilbert Roe's argument that a defendant's advocacy can be punished "only when coupled

punishing defamation, obscenity, and advertisements for lotteries, asserted that the legislature could constitutionally punish "matter which is injurious to society according to the standard of the common law." Id.

142. Goldman v. Reyburn, 18 Pa. Dist. R. 883 (1909).

143. Id. at 884 .

144. Id. the court also maintained that Goldman's political views signified that she did not have "hands that are clean." As a result, she could not claim the equitable relief of an injunction. $I d$. at 885 .

145. Id.

146. State v. Quinlan, 86 N.J.L. 120, 91 A. 111 (Sup. Ct. 1914), aff'd, 87 N.J.X. 333, 93 A. 1086 (Ct. Err. \& App. 1915).

147. State v. Boyd, 86 N.J.L. 75, 91 A. 586 (Sup. Ct. 1914), rev'd on other grounds, 87 N.J.L. 560, 94 A. 807 (Ct. Err. \& App. 1915).

148. State v. Quinlan, 86 N.J.L. 120, 121-22, 91 A. 111, 112 (Sup. Ct. 1914), aff'd, 87 N.J.L. 333, 93 A. 1086 (Ct. Err. \&: App. 1915); see State v. Boyd, 86 N.J.L. 75, 76, 91 A. 586, 586 (Sup. Ct. 1914), rev'd on other grounds, 87 N.J.L. 560, 94 A. 807 (Ct. Err. \& App. 1915).

149. State v. Boyd, 86 N.J.L. 75, 79, 91 A. 586, 588 (Sup. Ct. 1914), rev'd on other grounds, 87 N.J.L. 560, 94 A. 807 (Ct. Err. \& App. 1915); see State v. Quinlan, 86 N.J.L. 120, 126, 91 A. 111, 114 (Sup. Ct. 1914), aff'd, s7 N.J.L. 333, 93 A. 1086 (Ct. Err. \& App. 1915). 
with some acts of destruction in pursuance of such advocacy."150 According to the court,

free speech does not mean unbridled license of speech, and ... language tending to the violation of the rights of personal security and private property, and toward breaches of the public peace is an abuse of the right of free speech for which, by the very constitutional language involved, the utterer is responsible. ${ }^{151}$

Although conceding that the consequences of speech are relevant to its legality, the court concluded that the prohibited advocacy itself "complete[d]" the crime defined by the statute. ${ }^{152}$

State courts sometimes used the bad tendency rationale to attribute responsibility to radicals for the potential lawlessness of hostile audiences, however moderate the expression or unreasonable the response. Sustaining a conviction for the public display of a red flag, the Supreme Judicial Court of Massachusetts held constitutional a statute forbidding the use in a parade of a red or black flag or of any flag "which may be derogatory to public morals."153 According to the court, statutes designed to preserve the public safety "cannot be stricken down as unconstitutional unless they manifestly have no tendency to produce that result." Citing dictionary definitions of the red flag as a "revolutionary and terroristic emblem," the court reasoned that the legislature could legitimately view it as the symbol of ideas hostile to established order and therefore "likely to provoke turbulence" if carried in parades. ${ }^{154}$

The Supreme Court of Michigan similarly upheld the convictions of socialists for having "infuriated the local public" by displaying the red flag. ${ }^{155}$ The court found that the socialists had actual knowledge that this display "would excite fears and apprehension" and "provoke violence and disorder" as a "natural and inevitable consequence." The fact that the public peace was disturbed, not by the socialists, but by "those whose sentiments they offended," provided no excuse; both groups "jointly invaded" the rights of the public.156 Although ac-

150. State v. Boyd, 86 N.J.L. 75, 80, 91 A. 586, 588 (Sup. Ct. 1914), rev'd on other grounds, 87 N.J.L. 560, 94 A. 807 (Ct. Err. \& App. 1915).

151. Id. at $79,91 \mathrm{~A}$. at $587-88$ (referring to free speech provision of state constitution).

152. State v. Quinlan, 86 N.J.L. 120, 127, 91 A. 111, 114 (Sup. Ct. 1914), aff'd, 87 N.J.L. 333, 93 A. 1086 (Ct. Err. \& App. 1915).

153. Commonwealth v. Karvonen, 219 Mass. 30, 31, 106 N.E. 556, 556 (1914).

154. Id. at 32, 106 N.E. at 557. But cf. Stromberg v. California, 283 U.S. 359 (1931) (reversing conviction under unconstitutionally vague statute prohibiting display of red flag as emblem of opposition to organized government).

155. People v. Burman, 154 Mich. 150, 155, 117 N.W. 589, 591 (1908).

156. Id. at 156,117 N.W. at 592 . 
knowledging the socialists' right "to propagate their political views," the court "emphatically" denied that in so doing they were permitted to violate the law. ${ }^{157}$ In an analogous case, a New York appellate court affirmed the conviction of Upton Sinclair for leading a peaceful demonstration in front of the Standard Oil Company building to protest John D. Rockefeller's alleged responsibility for killing women and children during labor unrest in Colorado. ${ }^{158}$ If public "reprobation" is likely "to be resented," the court held, "the behavior evidencing such reprobation is unlawful as tending to a breach of the peace," even though conducted in a peaceable and courteous manner. The conviction protected "the public interest in the enforcement of law and the preservation of order"159 and did not violate Sinclair's First Amendment rights.

Two decisions by the Supreme Court of New Jersey reversing convictions in cases arising out of the IWW strike in Paterson, however, protected free speech in contexts where most courts might have been tempted to use the bad tendency doctrine to reach the opposite result. In Haywood v. Ryan, ${ }^{160}$ it reversed a conviction of IWW leader Bill Haywood for disorderly conduct, finding that Haywood was not responsible for the crowd he attracted. The court concluded that under the erroneous construction of the lower court, "almost every person having something more than a local reputation sufficient to arouse the curiosity of the public, would be liable to be apprehended as a disorderly person." 161

In overturning the conviction of a local newspaper publisher, the same court reached a remarkable decision which foreshadowed Learned Hand's famous opinion in Masses Publishing Co. v. Patten.162 During the strike, the publisher had printed an article accusing the police of brutally attacking peaceful strikers, and calling them "drunken Cossacks," "brass-buttoned anarchists," and "professional strike breakers" owned by the Manufacturers' Association. ${ }^{163} \mathrm{He}$ was found guilty of violating a state statute that punished those who "advocate the

157. Id. at 157,117 N.W. at 592 .

158. People v. Sinclair, 86 Misc. 426 , 149 N.Y.S. 54 (Ct. Gen. Sess. 1914). Gilbert Roe represented Sinclair.

159. Id. at 438,149 N.Y.S. at 61 . But cf. Terminiello v. Chicago, 397 U.S. 1, 4 (1949) (striking down disorderly conduct conviction for activity that "stirs the public to anger" and "invites dispute," because "a function of free speech under our system of govern. ment is to invite dispute").

160. 85 N.J.L. 116,88 A. 820 (1913).

161. Id. at $118,88 \mathrm{~A}$. at 821 . In Sinclair, the New York court distinguished Haywood by pointing out that Sinclair intentionally drew a crowd. 86 Misc. at 439,149 N.Y.S. at 62.

162. 244 F. 535, 540 (S.D.N.Y.), rev'd, 246 F. 24 (2d Cir. 1917) (Espionage Act punishes direct incitement to crime, but not mere agitation); see note 415 infra.

163. State v. Scott, 86 N.J.L. 133, 134-35, 90 A. 235, 235 (1914). 
subversion and destruction by force of any and all government" or "encourage hostility or opposition to any and all government." 1 it After noting that the statute would be "clearly unconstitutional" if it encompassed this article within its prohibitions, the court concluded that the statute proscribed only the advocacy of lawlessness. ${ }^{105}$ Any other construction would "prevent all free discussion" regarding changes in government, "would preclude fair criticism on the conduct of public officials," and "would silence the public press."16i Unlike Justice Holmes' opinion in a similar situation in Fox, the Supreme Court of New Jersey found that the article did not violate the law, even though it was "couched in hot and intemperate language" and might subject its author and publisher to indictment for criminal libel. ${ }^{167}$

Obscenity and Public Morals. The bad tendency standard also governed the law of obscenity. American courts, in applying the common law or interpreting the federal Comstock Act, ${ }^{168}$ adopted from English law the famous Hicklin test of obscenity. That test considered "whether the tendency of the matter charged as obscenity is to deprave and corrupt those whose minds are open to such immoral influences, and into whose hands a publication of this sort may fall."100

Courts extended this approach to prohibit publications that harmed the "public morals." The Supreme Court of Errors of Connecticut affirmed a conviction under a law prohibiting publications "principally made up of criminal news, police reports, or pictures and stories of deeds of bloodshed, lust, or crime" because "[i]t is impossible to say . . . that such publications do not tend to public demoralization as truly as descriptions of mere obscenity."170 Simi-

164. Id. at $134,90 \mathrm{~A}$. at 235 .

165. Id. at $138-39,90 \mathrm{~A}$. at 237 (vice of anarchy is not so much belief in state or condition of society without law, but rather in "promotion and encouragement of disobedience to and contempt of existing laws").

166. Id. at 138, $90 \mathrm{~A}$. at 237 . The court pointed out that the statute, enacted as a result of the excitement following the assassination of President McKinley, was "very apt to reflect the crude and undigested sentiment of a public upheaval at the cost of encroachments on constitutional rights." Id. at 136, 90 A. at 236.

167. Id. at 139, $90 \mathrm{~A}$. at 237; cf. pp. 535-36 supra (discussing Holmes' opinion in Fox).

168. Comstock Act, ch. 258, $§ 2,17$ Stat. 598 (1873) (current version at 18 U.S.C. $\$ 1461$ (1976)); see note 41 supra.

169. The Queen v. Hicklin, L.R. 3 Q.B. 360, 37I (1868); see, e.g., United States v. Harmon, 45 F. 414, 417 (D. Kan. 1891); United States v. Bennett, 24 F. Cas. 1093, 1104 (C.C.S.D.N.Y. 1879) (No. 14,571); Commonwealth v. Havens, 6 Pa. Co. Ct. Rep. 545, 54950 (1888). But cf. Roth v. United States, 354 U.S. 476, 489 (1957) (expressly disapproving Hicklin test).

170. State v. McKee, 73 Conn. 18, 26, 27, 46 A. 409, 412, 413 (1900). But cf. Winters 


\section{Prewar Free Speech}

larly, the Supreme Court of Minnesota upheld the indictment of a defendant who, contrary to law, published an account of an execution. The court acknowledged that the article was "moderate" and did not "emphasiz[e] the horrors of executing the death penalty,"171 but it rejected as "altogether too restricted a view" the argument that the liberty of the press could not constitutionally be limited unless the publication was blasphemous, obscene, seditious, or scandalous. As long as the subject matter was "of such character as naturally tends to excite the public mind and thus indirectly affect the public good," it could be penalized.172 The court therefore deferred to the legislative judgment that "it is detrimental to public morals to publish anything more than the mere fact that the execution has taken place." 173

The bad tendency theory of obscenity, however, had an important detractor. In United States v. Kennerley, ${ }^{174}$ Judge Learned Hand questioned the validity of the Hicklin test. He criticized Hicklin as an anachronistic example of "mid-Victorian morals," though he considered himself bound by precedent to apply it. ${ }^{175}$ Hand believed that anything "which is honestly relevant to the adequate expression of innocent ideas" should not be judged obscene, no matter what language that expression takes. ${ }^{176}$ Assuming that this "abstract definition" would not be adopted, Hand argued in the alternative that a community standard of obscenity, defined on a case-by-case basis by jurors, would be a major improvement over Hicklin. According to Hand, the Hicklin test forces society "to accept for its own limitations those which may perhaps be necessary to the weakest of its members." Allowing jurors to define "the average conscience of the time" would be "perhaps tolerable."177 Hand never mentioned the First Amendment in Kennerley, but this decision, like his later opinion in Masses Publishing Co. v. Patten, criticized the bad tendency test and favored significantly more protection for speech than analogous cases decided by his contemporaries.

v. New York, 333 U.S. 507, 518-20 (1948) (similar statute unconstitutionally vague, thereby infringing freedom of speech and press); id. at 531-32 (Frankfurter, J., dissenting) (relying on McKee and Fox).

171. State v. Pioneer Press Co., 100 Minn. 173, 177, 110 N.W. 867, 868 (1907).

172. Id. at 176,110 N.W. at 868 .

173. Id. at 177,110 N.W. at 868-69.

174. 209 F. 119 (S.D.N.Y. 1913).

175. Id. at 120 .

176. Id. at 120-21.

177. Id. at 121 . 


\section{Libel}

Many American courts did not recognize a good faith privilege for publishers of defamatory falsehoods about public figures. ${ }^{178}$ Some judges even imposed liability if the accuracy of statements could not be determined.179

Despite numerous decisions to the contrary, however, the Supreme Court of Kansas allowed a qualified privilege to good faith publishers of defamatory falsehoods about candidates for public office. ${ }^{180}$ The court's opinion is even more remarkable for its detail and sophistication than for its result. In a thoughtful discussion of the history of the law of defamation, ${ }^{181}$ it recognized that the relationship between the First Amendment and the law of defamation had not been clarified and that "judicial decisions had often been narrow, illiberal and confusing." 182 As a result, the court considered it necessary to take into account "the needs and the will of society at the present time" in deciding cases involving liberty of the press. ${ }^{183}$ Using this approach, the court concluded that a democratic form of government requires the "freedom to canvass in good faith the worth of character and qualifications of candidates for office." 184 The court held that such discussion must be privileged because the substantial public benefit far outweighs the slight risk of injury to private character. ${ }^{185}$ This

178. See, e.g., Negley v. Farrow, $60 \mathrm{Md} .158,177$ (1883); Burt v. Advertiser Newspaper Co., 154 Mass. 238, 242, 28 N.E. 1, 4 (1891) (Holmes, J.); Hamilton v. Eno, 81 N.Y. 116, 125-26 (1880); Post Publishing Co. v. Moloney, 50 Ohio St. 71, 88-89, 33 N.E. 921, 925-26 (1893).

179. See, e.g., Post Publishing Co. v. Hallam, 59 F. 530 (6th Cir. 1893). According to Judge Taft,

the danger that honorable and worthy men may be driven from politics and public service by allowing too great latitude in attacks upon their characters outweighs any benefit that might occasionally accrue to the public from charges of corruption that are true in fact, but are incapable of legal proof. The freedom of the press is not in danger from the enforcement of the rule we uphold.

Id. at 541. But see New York Times Co. v. Sullivan, 376 U.S. 254, 279.80 (1964) (requiring public official to prove knowledge of falsity or reckless disregard for truth to recover damages from publisher).

180. Coleman v. MacLennan, 78 Kan. 711, 98 P. 281 (1908).

181. Id. at 716-18, $98 \mathrm{P}$. at 283. The court cited the "ill-starred" Sedition Act of 1798 as an example of "how far ideas relating to the protection of personal character and governmental institutions were then unreconciled in legal theory with freedom of thought and expression upon public questions." Id. at 717, 98 P. at 283.

182. Id. at $718,98 \mathrm{P}$. at 283.

183. Id.

184. Id. at 723,98 P. at 285.

185. Id. at $724,98 \mathrm{P}$. at 286 . The court recognized that, at times, the injury to the reputations of individuals might be great, but asserted that the "public welfare" is more important. $I d$. 
early example of judicial balancing was as unusual and as prescient ${ }^{186}$ as Hand's analysis of obscenity in Kennerley.

A New York appellate court, although not extending this privilege to cover false statements made in good faith, recognized through similar reasoning the importance of the right to express opinions criticizing public officials. Because " $[t]$ he prevailing or majority opinion is often the wrong one," the court explained, "the law gives full latitude to the expression of any and all opinions on things of general concern." 187 Only despotic governments, the court added, force people to criticize public officials "in whispers or with bated breath." According to the court, "open discussion and criticism ... is the great safeguard of free government, and of pure government."18s Prosecutions and convictions under the Espionage Act would soon punish "open discussion and criticism" of American war policy by dissidents. But in the comparatively mild context of corruption charges against a village official, at least one court before the war identified and applied this important principle.

\section{Political Speech}

Unlike the majority of the Supreme Court in Ex parte Curtis ${ }^{188}$ or Justice Holmes in McAuliffe, ${ }^{190}$ some state supreme courts protected political expression, often under the free speech provisions of their state constitutions. Many of these courts explicitly recognized the value of political speech in a democratic society.

The Supreme Court of Wisconsin, in marked contrast to Ex parte Curtis, struck down a corrupt practices act that placed severe limitations on spending for political purposes by persons other than candidates or members of a party committee. ${ }^{101}$ This decision, based on both the federal and state constitutions, protected the right of a private citizen to spend money "in investigating the governmental, political, and financial affairs of the state and communicating the results of his investigations" to the voters. ${ }^{102}$ "Almost every forward step in political and governmental affairs," the court concluded, "comes

186. The Supreme Court cited Coleman $v$. MacLennan at length in New York Times Co. v. Sullivan, 376 U.S. 254, $279-82$ (1964), in support of its announced standard. See note 179 supra.

187. Howarth v. Barlow, 113 A.D. 510, 513-14; 99 N.Y.S. 457, 459 (1906).

188. Id. at $514 ; 99$ N.Y.S. at 459.

189. 106 U.S. 371 (1882); see p. 531 supra.

190. McAuliffe v. Mayor of New Bedford, 155 Mass. 216, 29 N.E. 517 (1892); see note 63 supra.

191. State v. Pierce, 163 Wis. 615, 158 N.W. 696 (1916).

192. Id. at 618,158 N.W. at $697-98$. 
as the result of long agitation and discussion in the press, on the rostrum, and in the open forum of personal contact," often continuing "for years before the idea is formally indorsed by any [political] party." Moreover, the court asserted, at times "devoted citizens firmly believe that no organized political party stands for the right or deserves support and that an independent candidacy is necessary." ${ }^{103}$ If the spending restrictions were not an abridgment of freedom of speech, the court concluded, "it would be difficult to imagine what would be."194

The Supreme Court of Virginia, resting primarily on the free speech clause of the state constitution, invalidated a statute that prohibited a variety of public officials, including judges and educators, from actively participating in politics. ${ }^{195}$ The statute defined active participation to include political speeches and official involvement in political meetings. ${ }^{190}$ After an unsuccessful attempt to distinguish $E x$ parte Curtis, ${ }^{107}$ the court stressed that the state constitutional protection of free speech is "guaranteed to all the citizens of the state, not to any portion or any class of citizens." To deprive some citizens of free speech solely because they are public officials, the court held, is unconstitutional. ${ }^{108}$ The Supreme Court of Missouri, also relying on the state constitution, invalidated a law that required all groups publishing reports or recommendations on candidates for public office to state the supporting facts and the names and addresses of all persons who furnished them. ${ }^{199}$ "If a publication is neither blasphemous, obscene, seditious or defamatory," the opinion held, "then un-

193. Id. at 620,158 N.W. at 698 .

194. Id. at 619, 158 N.W. at 698 ; cf. Buckley v. Valeo, 424 U.S. 1, 44-51 (1976) (striking down limits on "independent" political expenditures).

The same court overruled, on First Amendment grounds, a contempt citation issued to a critic of his judicial record by a judge who was a candidate for reelection. State ex rel. Attorney General v. Circuit Court, 97 Wis. I, 72 N.W. 193 (1897). The court held that the judge could bring an action for libel, but that sustaining the contempt power in these circumstances would effectually "gag the press, and subvert freedom of speech." Id. at 12,72 N.W. at 196.

195. Louthan v. Commonwealth, 79 Va. 196 (1884).

196. Id. at 197 .

197. Id. at 204.

198. Id. at 206. This court viewed constitutional rights as evolving rather than static, an atypical approach during an era of judicial formalism. It cited as the decisive historical turning point the popular reaction against the "ambitious and despotic rulers" responsible for the Sedition Act of 1798, "which trammeled freedom of speech." Id. at 204-05.

The Supreme Court, however, continues to allow comparable restrictions on federal employees, citing for support Ex parte Curtis, 106 U.S. 371 (1882). Two decisions have upheld the Hatch Act, 5 U.S.C. $\$$ 7324(a) (1976), which bars civil servants from taking an "active part in political management or in political campaigns." United States Civil Serv. Comm'n v. National Ass'n of Letter Carriers, 413 U.S. 548, 554-55 (1973); United Public Workers v. Mitchell, 330 U.S. 75, 96-98 (1947).

199. Ex parte Harrison, 212 Mo. 88, 110 S.W. 709 (1908). 
der the Constitution of this State, no court has the right to restrain it, nor the Legislature power to punish it." ${ }^{200}$

\section{Labor Injunctions}

The development of injunctions as the "central lever" in "the administration of justice between employer and employee" 201 provided another source of litigation over free speech issues. Toward the end of the nineteenth century, the courts expanded the injunction into "an enveloping code of prohibited conduct." 202 Courts issued injunctions to forbid various activities of union leaders and their supporters, thereby employing "the most powerful resources of the law on one side of a bitter social struggle." 203 Judges often used the same broad and vague injunction in numerous cases, without adaptation to the facts of the particular labor dispute. ${ }^{204}$ Many of the most outrageous injunctions were directed against speech and prohibited "opprobrious epithets," language that was "bad," "abusive," "annoying," or "indecent," and words such as "scab," "traitor," and "unfair."205 Some judges even held that picketing per se is unlawful. ${ }^{206}$

The courts rarely gave elaborate theoretical explanations for their use of labor injunctions. The decision of the Supreme Court of Michigan in Beck v. Railway Teamsters' Protective Union, ${ }^{207}$ however, does contain some revealing analysis. Although acknowledging that the free speech clause of the Michigan Constitution prohibits injunctions against libels, the court, in order to avoid irreparable injury to property rights, upheld an injunction against a circular urging a boycott. The court found that the purpose of the circular was not just to libel the employer, but to intimidate and prevent the public from doing business with him. ${ }^{208}$ As did the United States

200. Id. at 93,110 S.W. at 710 .

201. F. Frankfurter \& N. Greene, The Labor InJunction 52 (1930).

202. Id. at 200 .

203. Id. at 81 .

204. Id. at $89-106$.

205. Id. at 98 .

206. For example, a federal judge in Iowa reasoned that "[t]here is and can be no such thing as peaceful picketing, any more than there can be chaste vulgarity, or peaceful mobbing, or lawful lynching. When men want to converse or persuade, they do not organize a picket line." Atchison, T. \& S.F. Ry. v. Gee, 139 F. 582, 584 (C.C.S.D. Iowa 1905); accord, Picrce v. Stablemen's Local 8760, 156 Cal. 70, 79, 103 P. 324, 328 (1909); A.R. Barnes \& Co. v. Chicago Typographical Union No. 16, 232 I11. 424, 436, 83 N.E. 940, 914-45 (1908); George Jonas Glass Co. v. Glass Bottle Blowers' Ass'n, 72 N.J. Eq. 653, 663-64, 66 A. 953, 957-58 (1907), aff'd, 77 N.J. Eq. 219, 225, 79 A. 262, 264-65 (1908).

207. 118 Mich. 497, 77 N.W. 13 (1898).

208. Id. at 526-27, 77 N.W. at 24-25. But cf. Thornhill v. Alabama, 310 U.S. 88, 98 106 (1940) (declaring unconstitutional overly broad statute prohibiting peaceful picketing). 
Supreme Court in Gompers, it seemed to view speech used in connection with a labor boycott as a "verbal act" beyond the protection of free speech guarantees. ${ }^{209}$

Some courts resisted the growing use of the labor injunction. A few even held that injunctions constitute prior restraints and are therefore incompatible with the constitutional protection of free speech. ${ }^{210}$ Other courts, without adopting such a rigid rule, conceded that picketing was not necessarily unlawful. For example, a federal appellate court sharply contrasted permissible "picketing" for purposes of communication, which appeals to a person's "free judgmen[t]," with unlawful "duress," which "intimidate[s] . . a effectually as . . physical assault." The court acknowledged that "[u]nder the name of persuasion, duress may be used," but it cautioned that "it is duress, not persuasion, that should be restrained and punished." Applying this distinction, the court refused to prohibit "picketing, as such."211 Justice Holmes, while still on the Supreme Judicial Court of Massachusetts, made a similar point in a famous dissent. He objected to an injunction that, in his view, prohibited "organized persuasion or argument, although free from any threat of violence, either express or implied." ${ }^{12}$ Holmes thought that the majority made the unwarrant-

209. See 118 Mich. at 526-27, 77 N.W. at 24-25; cf. Gompers v. Bucks Stove \& Range Co., 221 U.S. 418 (1911) (upholding labor injunction by distinguishing normal speech from "verbal act"); p. 532 supra (discussing Gompers).

The courts, by contrast, were more impressed by the claims of employers that "blacklisting" statutes, which required employers to provide written explanations to discharged employees, were unconstitutional. Most prewar decisions agreed with the argument that free speech implies a "correlative" right not to speak and that the blacklisting statutes violated this implicit right. See, e.g., Atchison, T. \& S.F. Ry. v. Brown, 80 Kan. 312, 315, 102 P. 459, 460 (1909); accord, Wallace v. Georgia, C. \& N. Ry., 94 Ga. 732, 22 S.E. 579 (1894); St. Louis S.W. Ry. v. Griffin, 106 Tex. 477, 485, 171 S.W. 703, 705 (1914).

210. See, e.g., Marx \& Haas Jeans Clothing Co. v. Watson, 168 Mo. 133, 143-50, 67 S.W. 391, 393-96 (1902) (statements by union members urging boycott may be punished but not enjoined). The court distinguished the circular at issue from enjoinable "verbal acts," which the court defined as threats with the "present ability to be carried into execution." Id. at 150,67 S.W. at 396. The Supreme Court used the term "verbal acts," defined somewhat differently, to sustain an injunction against a similar circular. Gompers v. Bucks Stove \& Range Co., 221 U.S. 418, 439 (1911); see pp. 531-32 supra.

Some courts, in very different contexts, held that the constitutional right to free speech precludes prior restraints. See Dailey v. Superior Court, 112 Cal. 94, 99-100, 41 P. 458, 460 (1896) (overturning order prohibiting performance and advertisements for play during pending trial in murder case on which play was based; any "abuse" could subsequently be punished and any defendant unfairly prejudiced by publication could be retried).

211. Iron Molders' Union No. 125 v. Allis-Chalmers Co., 166 F. 45, 51 (7th Cir. 1908); accord, Karges Furniture Co. v. Woodworkers Local 131, 165 Ind. 421, 431-33, 75 N.E. 877, 880-81 (1905); Everett Waddey Co. v. Richmond Typographical Union No, 90, 105 Va. 188, 197-98, 53 S.E. 273, 275-76 (1906).

212. Vegelahn v. Guntner, 167 Mass. 92, 104, 44 N.E. 1077, 1080 (1896) (Holmes, J., dissenting). 
ed assumption that picketing "necessarily carries with it a threat of bodily harm." 213

\section{Speech in Public Places}

The lower courts were generally hostile to challenges against statutes that prohibited speech in public places. Some of these decisions, unlike Davis v. Massachusetts, ${ }^{214}$ at least addressed free speech concerns while denying the free speech claim. Sustaining the conviction of a socialist professor for deliberately speaking without a permit required by local ordinance, the Supreme Court of Georgia illustrated the low priority often afforded First Amendment interests. ${ }^{215}$ The court pointed out that " $[t]$ he primary object of streets is for public passage"216 and that "[a] man has many constitutional and legal rights which he can not lawfully exercise in the streets of a city." ${ }^{217}$ As one example, it stated that " $[t]$ he constitutional right to exercise one's lawful vocation is quite as sacred and often more important than the right to make speeches, but the exercise of either right must yield to the municipal power properly exercised over the streets." 218

Other decisions upheld municipal ordinances prohibiting speech only in specified places. The reasoning of a California appellate court is typical:

This ordinance does not attempt to suppress freedom of speech, or seek to interfere with the citizen in the right to express his views upon any subject, political, religious or otherwise, as is suggested by petitioner. It simply specifies a certain district within the city wherein no one may do the things prohibited.219

The court acknowledged that it was unable to judge the reasonableness of the boundaries, but concluded that, "[w] here no abuse of discretion appears," the judiciary should defer to local legislative determinations. ${ }^{20}$

There were a few countervailing decisions. In several cases brought by members of the Salvation Army, courts overturned ordinances giv-

213. Id. at 105,44 N.E. at 1080 .

214. 167 U.S. 43 (1897); see pp. 529-30 supra.

215. Fitts v. City of Atlanta, $121 \mathrm{Ga} .567,571,49$ S.E. 793, 795 (1905). The city authorities had withdrawn without explanation a permit previously issued to him. He then advertised a street lecture to test the ordinance. $I d$. at 568-70, 49 S.E. at 793-94.

216. Id. at 570,49 S.E. at 794 .

217. Id. at 570,49 S.E. at 795 .

218. Id. at 571,49 S.E. at 795.

219. Ex parte Thomas, 10 Cal. App. 375, 377, 102 P. 19, 20 (Dist. Ct. App. 1909).

220. Id. 
ing local authorities broad discretion over the time, place, and manner of parades and public speeches. These decisions cited the value of public demonstrations and discussions to democratic government. The Supreme Court of Michigan, for example, invalidated a city ordinance by pointing out that "unregulated official discretion" 221 to control parades "would enable a mayor or council to shut off processions of those whose notions did not suit their views or tastes, in politics or religion, or any other matter on which men differ." 222 Acknowledging that reasonable restrictions on the "times and occasions" of public assemblies may be necessary, the court emphasized that regulation could only be justified because of actual or threatened harm rather than "because of the sentiments or purposes of the movement, if not otherwise unlawful." 223 It added that "to suppress things not absolutely dangerous, as an easy way of getting rid of the trouble of regulating them, is not a process tolerated under free institutions." 224

Similarly, the Supreme Court of Wisconsin declared unconstitutional a local ordinance that excepted only funerals, fire and militia companies, and political parties from the requirement of obtaining a discretionary permit from the mayor before parading on certain public streets while singing, shouting, or playing musical instruments. The court labeled the ordinance "entirely un-American and in conflict with the principles of our institutions and all modern ideas of civil liberty." ${ }^{225}$ In the court's opinion, the ordinance more closely resembled "petty tyranny" than "any fair or legitimate provision in the exercise of the police power of the state to protect the public peace and safety."226 "The spirit of our free institutions," an Illinois appellate court also observed, "allows great latitude in public parades and demonstrations, whether religious or political." As long as they are not a threat to the public peace and do not violate the rights of others, "every measure repressing them, whether by legislative enactment, or municipal ordinance, is an encroachment upon fundamental and constitutional rights." ${ }^{227}$

221. In re Frazee, 63 Mich. $396,407,30$ N.W. 72,76 (1886).

222. Id. at $406-07,30 \mathrm{~N} . \mathrm{W}$. at 76 .

223. Id. at $405,30 \mathrm{~N} . \mathrm{W}$, at 75 .

224. Id. at 404,30 N.W. at 74.

225. State ex rel. Gerrabad v. Dering, 84 Wis. 585, 594-95, 54 N.W. 1104, 1107 (1893).

226. Id. at 594, 54 N.W. at 1107. The court stressed that the ordinance denied "the equal protection of the laws" because it lacked "an equal and uniform application to all persons, societies, or organizations similarly circumstanced," and was "susceptible of unjust discriminations." Id. at 595, 54 N.W. at 1107-08.

227. Rich v. City of Naperville, 42 Ill. App. 222, 223-24 (1891). The court notcd that since the landing of the Mayflower, the right to parade in a peaceable manner and for a lawful purpose has been "among the fundamental rights of a free people." Id. at 223. 
It is, of course, revealing that courts did not apply the theoretical standards developed in the relatively innocuous Salvation Army cases ${ }^{228}$ to similar claims raised by socialists. Most dramatically, the Supreme Court of Michigan, which in its Salvation Army case in 1886 warned against "suppress[ing] things not absolutely dangerous," 229 held in 1908 that socialists could not parade with red flags because their display would offend and arouse the general public. ${ }^{230}$ In the Salvation Army case the court pointed out that parades "with banners and other paraphernalia" have been "customary, from time immemorial, in all free countries, and in most civilized countries, for people who are assembled for common purposes." 231 The same court was later unmoved by the socialists" argument that the red flag "is an emblem of their order, and signifies brotherhood." 232

\section{The Judicial Tradition}

These decisions demonstrate that many free speech cases, involving a great variety of litigants and issues, reached the courts in the generation before Congress passed the Espionage Act. The overwhelming weight of judicial opinion in all jurisdictions offered little recognition and even less protection of free speech interests. Although radical and dissident activity prompted many of the prosecutions, it alone cannot account for the restrictive results. Political speech by government employees, public sermons by ministers, and newspaper reports of crime also produced decisions that rejected First Amendment claims. A general hostility to the value of free expression permeated the judicial system. This pervasive hostility had few doctrinal underpinnings, nor was it openly expressed. Judges often emphasized the sanctity of free speech in the very process of reaching adverse decisions in concrete cases.

Some opinions, predominantly in the state courts, reveal that restrictive decisions did not reflect the entire judicial spectrum. Courts occasionally protected freedom of expression and pointed to issues that contemporary scholars and postwar judicial decisions addressed

228. Not all protective "time, place, and manner" decisions involved the Salvation Army, see, e.g., State v. Hughes, 72 N.C. 25 (1875) (noisy but peaceful celebration of Emancipation Proclamation), and not all decisions protected the Salvation Army, see, e.g., Commonwealth v. Plaisted, 148 Mass. 375, 19 N.E. 224 (I889) (upholding conviction for playing music in public streets without permit).

229. In re Frazee, 63 Mich. 396, 404, 30 N.W. 72, 74 (1886); see p. 556 supra.

230. People v. Burman, 154 Mich. 150, 155-56, 117 N.W. 589, $591-92$ (1908); see pp. 546-47 supra.

231. In re Frazee, 63 Mich. 396, 404, 30 N.W. 72, 74 (1886).

232. People v. Burman, 154 Mich. 150, 153, 117 N.W. 589, 591 (1908). 
more systematically. For the most part, however, the few relatively libertarian opinions were not analytically more rigorous than the norm for this period. Even when supporting free speech claims, they generally did not explain in any meaningful detail the basis for the result. They did not attempt to develop guidelines for determining what constitutes speech or when speech may be unlawful, perhaps because they devoted so little attention to considering the interests the First Amendment was designed to safeguard.

The analytical sterility of most opinions, regardless of outcome, was self-perpetuating. Judges did not challenge each other to think deeply about the First Amendment and were therefore less likely to revise their views. But there were a sufficient number of libertarian decisions to suggest that judges were not simply unable to conceive of more generous approaches to the First Amendment. It seems likely that many judges who reached restrictive decisions knew some of the protective precedents and consciously, if seldom explicitly, rejected them. ${ }^{233}$ In any event, the fact that some prewar judges could be sympathetic to free speech claims suggests that the tradition of insensitivity was not so dominant that only an intellectual breakthrough in First Amendment interpretation could have created the possibility of different results. The existence of protective decisions, even more than their relative paucity, emphasizes the general judicial hostility toward free speech before World War One.

The prewar cases also demonstrate that the decisions in Selective Draft Law and Espionage Act prosecutions during and immediately after World War One were neither a temporary aberration from a libertarian tradition nor the consequence of an initial encounter with the First Amendment. The wartime and postwar decisions were depressingly similar to their prewar antecedents. They continued an existing tradition of hostility to free speech claims by reaching restrictive results through simplistic justifications that rarely considered the meaning of the First Amendment. To give the most obvious examples, Justice Holmes' decisions in the first Espionage Act cases ${ }^{234}$ are not appreciably different in analysis or result from his prewar

233. Free speech claimants in some cases cited protective decisions by other courts. See, e.g., Brief of Appellants, supra note 79, at 21-22, 47-54 (Mutual Film Corp. v. Industrial Comm'n of Ohio) (relying on cases invalidating prior restraints, see note 210 supra); Bricf for Plaintiff in Error, supra note 60, at 55-61 (Davis $v$. Massachusetts) (citing cases permitting parades by Salvation Army); In re Flaherty, I05 Cal. 558, 558-59, 38 P. 981 (1895) (reported only in California Reports) (summarizing petitioner's argument, which cited four protective Salvation Army decisions); $c f . i d$. at 565-66, $38 \mathrm{P}$. at 983-84 (court's attempt to distinguish protective cases).

234. See pp. 584-86 infra. 
decisions in Patterson v. Colorado and Fox v. Washington. On the other hand, this established tradition of hostility makes even more dramatic the rapid reorientation of First Amendment theory by the postwar civil libertarians, whose ranks Justices Holmes and Brandeis soon joined.

\section{Legal Scholarship}

Scholars as well as judges considered the meaning of freedom of expression in the generation before Congress passed the Espionage Act. Just as case law preceded Schenck, treatises and articles anticipated Chafee. This legal scholarship stands in striking contrast to the tradition of judicial hostility to First Amendment values. Unlike the prewar decisions, which were generally restrictive and poorly reasoned, much of the legal writing of this period used sophisticated analyses to reach protective standards. Relatively libertarian theory, moreover, was not the province of eccentric iconoclasts. The authors included some of the most eminent scholars in the country. They offered convincing doctrinal support for free speech claims, but their ideas did not gain significant judicial acceptance until after the United States entered World War One.

Within this scholarship, five authors were particularly important. ${ }^{235}$

235. Other scholarship published during this period, although not as comprehensive or insightful as the work of the five authors who will be discussed in detail, is also worth examining. Most of these other writers simply summarized the existing case law, often approvingly, but some of them addressed a particular free speech issue in depth. See, e.g., Biklé, The Jurisdiction of the United States over Seditious Libel, 50 AM. L. Reg. 1, 26 (1902) (First Amendment permits punishment for seditious libel and other speech that "seriously affect[s] the stability and efficiency of government"); Rogers, The Extension of Federal Control Through the Regulation of the Mails, 27 HARv. L. REv. 27 (1913) (warning against increased reliance on postal power to restrict First Amendment rights indirectly, but not criticizing Supreme Court decisions about which author clearly uncomfortable); Rogers, Federal Interference with the Freedom of the Press, 23 YALE L.J. 559, 579 (1914) (analyzing "constitutional incidents in which the liberty of the press has figured" and concluding that "in no case has it been abridged"); Veeder, Freedom of Public Discussion, 23 Harv. L. Rev. 413 (1910) (thorough review of law of defamation, advocating full debate on matters of public interest and protection for false statements of fact); Note, Restrictions on the Freedom of the Press, 16 HARv. L. REv. 55, 56 (1902) (observing without disapproval that free speech guarantees are "little more than a declaration of English common law principles").

Given the current assumption that there was little or no First Amendment activity before World War One, it is interesting to read in a law review note published in 1916 that, except for the Fourteenth Amendment, the First Amendment is "the most popular as well as the most versatile of the constitutional guaranties." Note, Constitutional LawFreedom of Specch and of the Press-Recent Decisions, 65 U. PA. L. REV. 170, I70 (1916). This note identified the growing "struggle between capital and labor" and "the increase of reform legislation of doubtful constitutionality" as the two major sources of First Amendment litigation. $I d$. at 174 .

Case and Comment devoted its November 1915 issue to a "Free Speech Number." The 
Two respected and widely cited treatises, Thomas Cooley's Constitutional Limitations ${ }^{236}$ and Ernst Freund's The Police Power, ${ }^{237}$ included sections on freedom of speech. At the annual meeting of the American Sociological Society in 1914, Henry Schofield, a professor at Northwestern University Law School, presented a comprehensive paper on "Freedom of the Press in the United States." 238 Roscoe Pound, perhaps the most influential legal scholar of his generation, wrote two articles in the Harvard Law Review that, while limited in scope, offered highly original and provocative interpretations of the First Amendment. ${ }^{239}$ The prodigious theoretical writings of Theodore Schroeder, the guiding force behind the Free Speech League, ${ }^{240}$ were the most extensive and libertarian treatments of freedom of speech in the prewar period. ${ }^{241}$ Despite their often convoluted style and hysterical tone, Schroeder's writings were an early and comprehensive statement of what modern scholars would describe as an "absolutist"

articles are essentially descriptive, but several characterized from different perspectives the state of the law on free speech. Two authors approved of existing case law, Ackerly, Constilutional Freedom of Speech and of the Press, 22 CASE \& CoM. 457 (1915); Chamberlain, Freedom of Speech in Public Streets, Parks and Commons, 22 CASE \& Com. 461 (1915), while two others criticized the prevailing judicial tradition as overly restrictive, Morton, Free Speech and Its Enemies, 22 CASE \& CoM. 471 (1915); Shepard, Freedom of Speech in Industrial Controversies, 22 CASE \& COM. 466 (1915).

236. T. Cooley, Constitutional Limitations (7th ed. 1903); see note 322 infra (discussing reception of Cooley's treatise).

237. E. Freund, supra note 28.

238. Schofield, Freedom of the Press in the United States, 9 AM. Soc. Soc'y: PAPERS \& Proceedings 67 (1914), reprinted in $2 \mathrm{H}$. Schofield, Essays on Constitutional Law and EQuiry 510 (1921). In his lengthy "bibliographical note," Chafee singled out Schofield's article as "[t]he best discussion of the legal meaning" of freedom of the press. ChafceFreedom of Speech in War Time, supra note 3, at 932 n.I.

239. Pound, Equitable Relief Against Defamation and Injuries to Personality, 29 Harv. L. Rev. 640 (1916) [hereinafter cited as Pound-Equitable Relief]; Pound, Interests of Personality (pts. 1-2), 28 HARv. L. REv. 343, 445 (1915) [hereinafter cited as Pound-Personality]. 240. See note 19 supra (discussing Schroeder and Free Speech League).

241. See, e.g., T. Schroeder, Free SPEech for Radicals (enl. ed. 1916); T. Schroeder, "Orscene" Literature and Constitutional Law (1911). These collections of essays are somewhat disorganized and repetitive, as Schroeder himself realized. In sending a copy of "Obscene" Literature and Constitutional Law to Chafee, Schroeder explained that he had made "a hasty grouping of magazine essays without time for planning the book and revision." Letter from Theodore Schroeder io Zechariah Chafee, Jr. (Oct. 1, 1919) (Zechariah Chafee, Jr., Papers, Box 14, Folder 26, Harvard Law School Library).

Theodore Schroeder, A Cold Enthusiast (R. McCoy ed. 1973) (on file with Yale Law Journal) is an indispensable guide to Schroeder's publications. It consists largely of a lengthy annotated bibliography of works by and about Schroeder divided by subject, a list of other Schroeder bibliographies, and a summary of the ninety-one boxes in the Schroeder Papers. Schroeder's works include a FREE SPEECH BibliograpHY (1922) and numerous articles in legal periodicals. See, e.5., Schroeder, The Constitution and Obscenity Postal Laws, 69 Albavy L.J. 334 (1907); Schroeder, Political Crimes Defined, 18 Mich. L. REv. 30 (1919) ; Schroeder, Presumptions and Burden of Proof as to Malice in Criminal Libel, 49 AM. L. Rev. 199 (1915) [hereinafter cited as Schroeder-Malice in Criminal Libel]. 
approach to the First Amendment. Unfortunately, they have failed to receive the serious scholarly attention they deserve. ${ }^{242}$

These scholars rarely described or criticized each other's arguments. They sometimes cited cases as raw material for the presentation of free speech issues, but rarely as guides to analysis, an understandable approach given the poor quality of judicial precedents. Nor did they rely on prior scholarly treatment of the First Amendment, perhaps because none of significance existed. ${ }^{243}$ Nevertheless, all five discussed a number of similar themes and, despite differences in emphasis, their published work reveals broad areas of agreement.

Like their modern counterparts, these scholars were most united in their criticisms of judicial decisions. They castigated American courts for adopting as a constitutional standard Blackstone's position that free speech means nothing more than the prohibition of prior restraints. Pound and Schofield accused judges of failing to make useful distinctions between protected and unprotected speech. ${ }^{244}$ Pound pointed out the courts' occasional "over-insistence" upon the state's interest in security, ${ }^{245}$ and Schofield called the practice of holding newspaper editors in contempt for criticizing judicial conduct "intolerable" ${ }^{248}$ and a reestablishment of the Star Chamber. ${ }^{247}$ "When judges in solemn and deliberate opinions," Schofield further complained,

242. I have found Auerbach, supra note 19, although confined to the contents of the volume he introduces, to be the best discussion of the substance of Schroeder's work. Several modern scholars have commented on Schroeder's significance, see, e.g., P. BoYER, Purity in Print $41-42$ (1968); Freedom of the Press from Hamilton to the Warren Court 279.80 (H. Nelson ed. 1967) (editor's introduction to article by Schroeder); J. Pavl \&. M. Schwartz, supra note 37, at 52.53; Emerson, supra note 22, at $656 \mathrm{n} .28$, and some have lamented his relative obscurity, see, e.g., L. LevY, supra note 5, at $157 \mathrm{n.76}$; Auerbach, supra note 19 , at $\mathrm{v}$.

"If you consider Freedom of Speech socially as well as politically," Freund wrote Chafee, "'Theodore Schroeder deserves a place in your bibliography." Letter from Ernst Freund to Zechariah Chafee, Jr. (Aug. 13, 1919) (Zechariah Chafee, Jr., Papers, Box 14, Folder 10, Harvard Law School Library). Chafee wrote to Schroeder with apologies for not citing his work in the Harvard Law Review article and promised to remedy this omission in a forthcoming book. Letter from Zechariah Chafee, Jr., to Theodore Schroeder (Sept. 29, 1919) (Zechariah Chafee, Jr., Papers, Box 14, Folder 26, Harvard Law School Library). In a "Bibliography on Freedom of Speech" at the end of Freedom of Speech, supra note 3, at 378 , Chafce observed that "[m]uch useful material is collected in the writings of Theodore Schrocder" and referred to a bibliography of Schroeder's work and to two of Schroeder's recent articles.

243. Without research into earlier periods of American history, it is impossible to determine if these prewar scholars ignored their predecessors, or simply had none.

244. Pound-Equitable Relief, supra note 239, at 651 ("[n]o very clear line is to be found in the decisions"); Schofield, supra note 238, at 102 (case law concerning libel "in an extremely loose and fluid state").

245. Pound-Personality, supra note 239 , at 454 .

246. Schofield, supra note 238 , at 115.

247. Id. at 107. 
"bracket striking and boycotting workmen with anarchists, then the tu quoque hot retort of the workmen that the judges are tools of the corporations is essentially human." ${ }^{248}$ Cooley, observing that the courts traditionally adapted "the plastic rules of the common law" to accommodate change, criticized judges for not developing the law of libel to provide greater protection for newspapers, "one of the chief means for the education of the people." 249

Schroeder was the most vitriolic in his criticism of judicial decisions. "[J]udicial history," he concluded, "abundantly shows that courts have destroyed and evaded the constitutional guarantee of freedom of speech and of the press" 250 by "dogmatically" creating "new exceptions and limitations, which are not represented by a single word in the constitution itself." 251 Judges, in Schroeder's opinion, had suffered from "an epidemic of respectable hysteria" that "incapacitate[d] them for critical thinking," 252 as demonstrated by their reliance on "stupid" and "meaningless epithets" such as "licentiousness." ${ }^{253}$ When judges complained that free speech could not be defined, they undertook "authoritatively to make their own intellectual bankruptcy the limit of the intellectual evolution of the race."2s4

These scholars did not simply criticize the courts. They attempted to construct theoretical support for their free speech values by investigating the meaning and limitations of the First Amendment. And though they evidently thought and wrote independently, a substantial degree of consensus emerged from their articles and books. They emphasized social interests in freedom of expression, including the positive influence of the exchange of ideas on the development of civilization and, particularly, the importance of political discussion to democratic government. Most of them distinguished "public" from

248. Id. at 106. In a calmer moment, Schofield simply observed that the courts seemed to consider freedom of the press to be "of little practical importance." Id. at 112.

249. T. CoOLEY, supra note 236 , at 641 . He also objected to defamation cases that narrowly defined the scope of privileged criticism of public officials and candidates for office. $I d$. at $624-28$.

250. T. Schroeder, Our Progressive Despotism, in Free SPEech For Radicals 73, 81 (enl. ed. 1916) (footnote omitted) [hereinafter cited as Schroeder-Our Progressive Despotism].

251. T. Schroeder, The Judicial Destruction of Freedom of the Press, in "OBSCENE" Literature and Constitutional Law 154, 155 (1911).

252. Schroeder-Our Progressive Despotism, supra note 250, at 81 .

253. T. Schroeder, Judicial Dogmatism on "Freedom of the Press," in "OBscene" LireRATURE AND Constitutional LAw 163, 204 (1911).

254. T. Schroeder, Methods of Constitutional Construction, in FreE SPEech FOR RAdrCals 82, 87 (enl. ed. 1916) [hereinafter cited as Schroeder-Constitutional Construction].

Freund, in contrast to the other four authors, refrained from making specific criticisms of judicial precedents, even though several of the cases he cited were inconsistent with his theoretical approach. See notes 284-85 infra. 
"private" concerns and argued that the First Amendment provides greater safeguards for the discussion of public affairs, especially by political and religious minorities. Several believed that broad protection for freedom of speech would reduce the threat of disorder and that its repression would be more likely to lead to actual violence. Consistent with these views, they generally rejected, as incompatible with the First Amendment, the English common-law crime of seditious libel, other tests based on the alleged bad tendency of speech, and Blackstone's opinion that free speech prohibits only prior restraints. With various degrees of explicitness, several recognized incitement to unlawful action as the point at which speech may constitutionally be punished. Most of these scholars also agreed that the First Amendment did not abolish common-law crimes such as libel and obscenity. However, they generally maintained that the First Amendment provides basic safeguards that could be expanded, but not limited, as society develops.

\section{A. The Social Interest in Free Speech}

Although none of these prewar scholars created an explicit methodology, they all examined the meaning of free speech through historical and functional rather than formal analyses. Their views derived from their understanding of its fundamental purpose, and they generally agreed that the First Amendment and analogous state constitutional guarantees were designed above all to ensure society's interest in free discussion. Schofield reiterated throughout his article that "the common right of public and truthful discussion of" public affairs exists as a right held in trust for the educational profit and benefit of the public" rather than as a private entitlement of individuals. ${ }^{255}$ Freund also stressed the First Amendment's role in guaranteeing " $[t]$ he most ample freedom of discussion of public affairs."

Cooley's treatise made explicit the relationship between freedom of expression and democratic government that seemed to underlie these assertions by Schofield and Freund. The First Amendment, in Cooley's opinion, is "essential to the very existence and perpetuity of free government." ${ }^{257}$ It checks the abuse of power by enabling citizens to make just criticisms of the conduct of persons in authority,

255. Schofield, supra note 238, at 91; see id. at $82,92,104$. According to Schofield, the First Amendment was intended to give constitutional force to the saying, "And ye shall know the truth, and the truth shall make you free." "Id. at 116.

256. E. Freund, supra note 28 , at 509 .

257. T. COOLEY, supra note 236 , at 596 . 
thereby holding them accountable to public opinion. The free and general discussion of public matters, moreover, is "absolutely essential to prepare the people for an intelligent exercise of their rights as citizens." 258

Although Pound viewed free speech as an "individual natural right" guaranteed by the First Amendment, he argued that the social interest in freedom of expression, though less recognized, is more important. The state protects itself by allowing its citizens free speech because the "individual will fight for his beliefs no less than for his life and limb and for his honor." Of greater and increasing importance, the free exercise of mental and spiritual faculties serves the community's interest in the "moral and social life of the individual." At times, even Theodore Schroeder, the "absolutist" and individualist who ceaselessly advocated unabridged freedom of speech, acknowledged that social interests in free expression outweigh personal ones. The First Amendment, in Schroeder's opinion, is "not only a question of the opportunity to speak, but of the more important opportunity of the whole public to hear and to read whatever they may choose, when all are free to offer." The "personal liberty of the speaker or writer" is less significant, Schroeder wrote, than the "racial intellectual development" of society, which is promoted by "keeping open all avenues for the greatest possible interchange of ideas." 200

\section{B. The Distinction Between Public and Private Speech}

This shared affirmation of the social importance of free expression, often traced to the historical origins of the First Amendment, led most of these scholars, with varying degrees of emphasis and explicitness, to distinguish "public" from "private" speech. ${ }^{261}$

\section{Schofield's Formulation of the Distinction}

Schofield placed major emphasis on the public-private distinction, which he considered crucial for a proper understanding of the First Amendment. According to Schofield, the American Revolution was

258. Id. at 604 .

259. Pound-Personality, supra note 239 , at 453 .

260. T. Schroeder, The Meaning of Unabridged "Freedom of Speech," in FreE SPEECH FOR RADICALS 37, 42 (enl. ed. 1916) [hereinafter cited as Schroeder-Unabridged "Freedom of Speech'].

261. For the most famous analysis of this distinction, see A. MEIkLEjohn, supra notc 77, at 38-41, 61-63, 68-70, 93-100. Recent scholarly discussions include BeVier, The First Amendment and Political Speech: An Inquiry Into the Substance and Limits of Principle, 30 Stan. L. Rev. 299 (1978); Bork, Neutral Principles and Some First Amendment Problems, 47 IND. L.J. 1, 26-35 (1971). 
intended to abolish the English common law governing freedom of expression. ${ }^{262}$ That definition prohibited all prior censorship but did not consider either the truth or the subject of the speech in evaluating its liability to subsequent punishment. Publications were unlawful, whether true or false, if the judges found that they had a "tendency ... to excite and move the people to change the existing order."263 In fact, there could be increased liability for true statements because they might be particularly likely to have a tendency to disrupt society. ${ }^{204}$ As Schofield pointed out, many prerevolutionary publications on politics in the colonies were seditious under this standard. ${ }^{265}$

Schofield concluded that the First Amendment "obliterated the English common-law test of supposed bad tendency"266 and "legalize[d] published truth on all matters of public concern." 267 It therefore imposed on judges the new responsibilities of distinguishing "private" from "public" speech and "of determining what is truth in a publication on a matter of public concern." 268 Schofield reasoned that true opinions, defined as inferences that could be drawn from true facts by "a fair-minded average man," are also covered by the First Amendment. Such protection, Schofield believed, "leaves a wide margin for the play and action of conflicting opinions on matters of public concern." 269

As corollaries to this view, Schofield acknowledged that the First Amendment does not extend either to "false news having a tendency to mislead the people on matters of public concern"270 or to any statements, whether true or false, dealing with "private" subjects. ${ }^{271}$ For example, even truthful advertisements are not encompassed by the First Amendment, for they are designed only "to promote private welfare" and are "not educational publications to promote the general welfare." 272 Because Schofield believed that "indecent, obscene,

262. Schofield, supra note 238 , at 78-79.

263. Id. at 74 .

261. This proposition is illustrated by the English common-law maxim, "the greater the truth the greater the libel." Id. at 79. But see $4 \mathrm{~W}$. BLAcKstone, supra note 86 , at " 150 (immaterial whether libel is true or false).

265. Schofield, supra note 238 , at 76 .

266. Id. at 78 .

267. Id. at 110 .

268. Id. at 79 .

269. Id. at 80 .

270. Id. at 81 .

271. Id. at 79 .

272. Id. at 105. For Schofield, advertisements included not only "[p]ublications advertising lotteries and other devices to make easy and quick money," $i d$. at 83 , but also "Unfair" and "We don't patronize" lists such as the ones enjoined in Gompers, see pp. 53132 supra. Those lists, he wrote, were simply advertisements "to make a strike or boycott 
and immoral publications, however true," lack educational value, he was confident that the First Amendment also preserved the commonlaw prohibitions against them. ${ }^{273}$

\section{Other Scholarly Support for the Distinction}

Cooley, Freund, and even Schroeder implicitly recognized the distinction between public and private speech, although none of them identified or analyzed it with as much precision or sophistication as Schofield. Alone among these scholars, Schofield connected the historical background of the First Amendment to the public-private distinction. Yet Cooley and Schroeder, without making this explicit connection, also maintained that the First Amendment was designed to eliminate the English common-law crime of seditious libel, and both stressed the importance of speech concerning public affairs.

Under the English rule, as summarized by Cooley, publications could be punished because of their "tendency . . . to excite disaffection with the government, and thus induce a revolutionary spirit."274 This principle, in Cooley's opinion, was always considered to be "unsuited to the condition and circumstances of the people of America." ${ }^{275}$ The First Amendment and similar provisions of state constitutions precluded the use of "repressive measures" to restrain free expression and secured the right of free discussion of public affairs. ${ }^{270}$ On the other hand, Cooley reasoned, the First Amendment does not apply to speech on private topics unless there is a "reason in public policy demanding protection to the communication." Therefore, commonlaw prohibitions against speech affecting "private character" or "public morals," including libel and obscenity, are consistent with constitutional guarantees. ${ }^{277}$

Schroeder was characteristically blunt in asserting the incompatibili-

more effective" and "are not exercises of the right of liberty of the press any more than 'U-Need-a-Biscuit,' or 'Drink Schlitz, the beer that made Milwaukee famous,' are exercises of the right." Id. at 105. But cf. Bates v. State Bar of Arizona, 433 U.S. 350 (1977) (state court disciplinary rule banning lawyer advertisements violates First Amendment protection of "commercial speech"); Virginia State Bd. of Pharmacy v. Virginia Citizens Consumer Council, Inc., 425 U.S. 748 (1976) (state may not ban advertising of retail prices of prescription drugs).

273. Schofield, supra note 238 , at 82.

274. T. CoOLEY, supra note 236 , at 612 .

275. Id. at 614-15. After acknowledging the passage of the Sedition Act of 1798, Cooley contended: "Its constitutionality was always disputed by a large party, and its impolicy was beyond question." He added that "it is impossible to conceive, at the present time, of any such state of things as would be likely to bring about its re-enactment, or the passage of any similar repressive statute." $I d$. at 613 (footnote omitted).

276. Id. at 604 .

277. Id. at 615; see id. at 604 . 


\section{Prewar Free Speech}

ty of seditious libel with the First Amendment. He noted that the colonists who supported the American Revolution "had no doubt been guilty of . . . seditious libel." The First Amendment, in Schroeder's opinion, was the attempt by the generation that won the Revolution to insure that future Americans would have the legal "right to advocate sedition and revolution." 278 More generally, the First Amendment provides that "every idea, no matter how unpopular, so far as the law is concerned, shall have the same opportunity as every other idea, no matter how popular, to secure the public favor." Because "only those ideas which were unpopular with the ruling classes were ever suppressed," the First Amendment was designed to end this "discrimination." 279 Yet even Schroeder acknowledged that the First Amendment provides stronger safeguards for public than for private speech. For example, he accepted Hamilton's test of truth "for good motives and for justifiable ends" as "sufficient liberty" for publications about the private affairs of private citizens, but rejected its application to "matters of public concern, which usually must be decided upon speculation and mere probability." 280

Although Freund believed that the law of seditious libel survived the ratification of the First Amendment, ${ }^{281}$ he also implicitly supported the division of speech into matters of public and private concern. Freund emphasized the importance of speech about public affairs ${ }^{2 \$ 2}$ and made clear his view that the First Amendment does not extend to communications lacking significant public interest. $\mathrm{He}$ pointed out that the First Amendment does not legalize defamation, obscenity, or speech corrupting "public morals." 283 At the same time, Freund stressed his rather broad view of what constitutes public affairs. "Freedom in the pursuit of art, literature and science is, as a matter of history, bound up with the freedom of religion and of speech and press, for it has practically never been opposed for other than religious or political motives." ${ }^{2 \$ 4}$ Obscenity, he maintained, should never include "[b]ona fide scientific or scholarly treatment of offensive

278. T. Schroeder, On Suppressing the Advocacy of Crime, in FreE SPEECH For Radicals 23, 33 (enl. ed. 1916) [hereinafter cited as Schroeder-Advocacy of Crime].

279. Schroeder-Unabridged "Freedom of Speech," supra note 260, at 42.

280. Schroeder-Malice in Criminal Libel, supra note 241, at 208-09; see pp. 568-69 infra (Schofield's discussion of Hamilton's test).

281. See pp. 569-70 infra (Freund's views on seditious libel).

282. E. FREUND, supra note 28 , at 509-13, 521 .

283. Id. at 506 .

284. Id. at 513. Freund concluded, contrary to the evidence of the case law, that "this freedom is established to the fullest extent." Id. He cited the convictions of the Haymarket anarchists, see p. 526 supra, and Johann Most, see pp. 543-44 supra, without criticizing the decisions. E. FreUnd, supra note 28, at 510-12. 
subjects," and the acknowledged state power to restrict indecent or immoral art and literature should be "exercised very sparingly." "ss

\section{The Expanding Conception of Free Speech}

Most of these authors also agreed that First Amendment guarantees, although never subject to abridgment, can be broadened to accommodate society's desire for additional free expression. Schofield indicated that speech previously considered private can become a matter of public concern. He recognized, for example, that the Hicklin test of obscenity could legitimately be criticized for preventing "truthful and useful publications of educational value on sex hygiene, commercialized vice, and other subjects, heretofore tabooed, but now thought by many fit topics for public discussion."286 Schofield apparently believed that either judicial construction or legislation could extend the definition of public speech, ${ }^{287}$ but he insisted that only a legislature could remove the restraint of truth and permit the publication of defamatory falsehoods about public issues. ${ }^{288}$

While analyzing the innovative formulation of liberty of the press advanced by Alexander Hamilton during litigation under the Sedition Act of 1798, Schofield also approved increased protection for speech on clearly private matters. Hamilton defined freedom of the press as "the right to publish, with impunity, truth, with good motives, and for justifiable ends." 289 That test, which had been incorporated into the free speech clauses of most state constitutions, had never been judicially construed. ${ }^{290}$ Schofield rejected its application to speech on public affairs because he feared it would be used by a legislature to revive the bad tendency test the First Amendment was designed to abolish. ${ }^{201}$ But Schofield did approve Hamilton's test as

285. E. Freund, supra note 28 , at 514 . Again, in an optimistic statement contrary to the evidence, Freund concluded that "[t]hese principles are so fully recognised by the practice of legislation that they stand unquestioned, even if lacking express judicial confirmation." Id.

286. Schofield, supra note 238, at 82; cf. p. 549 supra (discussing Hand's criticism of Hicklin in United States v. Kennerley, 209 F. 119 (S.D.N.Y. 1913)).

287. Schofield, supra note 238 , at 82 .

288. Id. at $80 \&$ n.2.

289. Hamilton first proposed this test during his argument in People v. Croswell, 3 Johns. Cas. 337, 393-94 (N.Y. Sup. Ct. 1804); see Schofield, supra note 238, at 89. According to Schofield, Hamilton's language "has been accepted as an extension of liberty of the press to all matters of private concern as well as matters of public concern, obliterating the distinction between the two. It is not clear that Hamilton so intended." Id. at 90 .

290. Schofield observed that "[n]obody really knows or seems to care very much about [its] true meaning." Schofield, supra note 238, at 95.

291. Id. at 92 n.2. Schofield cited the prosecutions under the Sedition Act of 1798 to criticize the bad tendency test, $i d$. at $86 \cdot 87$, and used the death of Socrates to illustrate its dangers, $i d$. at 92 n.2. 
a judicial limitation "[w] $w$ hen liberty of the press is extended to all matters of private concern." ${ }^{292}$ This additional but properly confined protection, Schofield believed, would safeguard desirable private speech without unfairly exposing individuals to invasions of privacy and other potential abuses of totally unrestrained freedom of expression..$^{203}$

Other prewar scholars, without focusing on the public-private distinction that so preoccupied Schofield, shared his receptivity to expanding conceptions of free expression. According to Cooley, free speech must always be "as broad as existed when the constitution which guarantees it was adopted," but the First Amendment does not preclude modifying the common law to protect additional speech.994 Schroeder acknowledged that the First Amendment could be interpreted either as permitting "more freedom than was contemporaneously conceded" or as providing for an "unabridged freedom of utterance." Even under the more limited theory of First Amendment protection, Schroeder argued, the framers built in "budding conceptions through which the idea of unabridged freedom of utterance must develop." ${ }^{295}$ The framers may not have intended to guarantee absolute freedom of expression, but neither did they mean to freeze the categories of protected speech in 1791.

Freund agreed that the meaning of the First Amendment should not be limited to the framers' original conception. Although he did not believe that the framers intended to abolish the common-law crime of seditious libel, ${ }^{206}$ Freund argued that the First Amendment should now be construed as precluding punishment for that crime. He pointed out that the last prosecution for seditious libel in the United States had probably taken place in 1805 , rendering the crime "practically obsolete." ${ }^{207}$ Many codifications of criminal law, he add-

292. Id. at 93 .

293. Id. at 93-94.

294. T. CooleY, supra note 236, at 615; see id. at 645 (expansion by legislature); p. 562 supra (expansion by courts).

295. Schroeder-Constitutional Construction, supra note 254, at 89-90.

296. E. FREUND, supra note 28, at 508. He pointed out that English constitutional struggles over government prosecutions for libel, which took place at the same time as the American Revolution, were resolved in Fox's Libel Act of 1792 by transferring the determination of libcl from the judge to the jury. The same principle, Freund claimed, was accepted in many, and perhaps most, American jurisdictions. Id. at 507-08. Thus, "freedom of political discussion and criticism," in the United States as well as in England, "was sought to be secured, not by altering the substantive law of libel, but by providing for a popular control of its administration." The enactment by Congress of the Sedition Act of 1798, in Freund's opinion, further demonstrated that the First Amendment was not understood to prohibit the common-law crime of seditious libel. Id. at 508 .

297. Id. at 508-09. Freund published his book before the litigation in United States v. Press Publishing Co., 219 U.S. I (1911), see p. 540 supra. 
ed, only covered defamations of individuals and did not refer to sedition. More importantly, "[c]ustom and public sentiment have come to sanction the widest latitude of criticism of the government," although it is generally impossible to prove the truth of such statements. Freund hoped that "the long continued practice of toleration may be accepted as sufficient warrant for modifying the interpretation of the express constitutional guaranty to that effect." ${ }^{\text {"298 }}$

\section{The Rejection of Blackstone}

Most of these prewar scholars went out of their way to point out that their First Amendment interpretations were inconsistent with Blackstone's limitation of free speech to the prohibition of prior restraints, ${ }^{209}$ a position followed in many American cases and accepted by the Supreme Court in Holmes' Patterson opinion. ${ }^{300}$ Schofield and Schroeder complained that American judges made a significant historical error in relying on Blackstone. Schofield called the courts "a failure" for holding that the First Amendment and the free speech clauses of state constitutions "are only declaratory of the anti-republican English common law of the days of Blackstone." 301 They "seem to have forgotten," he complained, "that the founders of the government are not distinguished for their reception of the English common law but for their adaptation of the democratic leaning and ten-

298. E. FReUnd, supra note 28, at 509.

299. According to Blackstone,

The liberty of the press ... consists in laying no previous restraints upon publications, and not in fieedom from censure for criminal matter when published . . . But to punish (as the law does at present) any dangerous or offensive writings, which, when published, shall on a fair and impartial trial be adjudged of a pernicious tendency, is necessary for the preservation of peace and good order, of government and religion, the only solid foundations of civil liberty.

$4 \mathrm{~W}$. BLACKstone, supra note 86, at *151-52. Although Blackstone linked his discussion of previous restraints to his willingness to punish speech for its bad tendency, these scholars attributed to him the rule on previous restraints and criticized the bad tendency theory in more general terms.

Blackstone's Commentaries, an attempt to codify the common law of England, were enormously successful on both sides of the Atlantic. L. FrIedman, supra note 22, at 16; G. GILmore, supra note 25, at 5. Blackstone became even more popular in the United States than in England, particularly in the decades after the American Revolution, when he provided a guide to the common-law tradition in a country without any significant case precedents or legal literature of its own. L. FrIEDMAN, supra note 22, at 88-89, 98 . There is a great deal of irony in the American reliance on Blackstone, for his Commen. taries were "a conservative reaction to the fundamental changes which the English judges were making in the apparently settled rules of English law." G. Grumore, supra note 25 , at 5 .

300. See pp. 533-34 \& note 86 supra.

301. Schofield, supra note 238, at 115. He described Holmes' Patterson opinion as simply "wrong." Id. at 110. 
dency of the constitutional side of it to a new career of popular freedom and equal justice." 302 Schroeder agreed. "The whole controversy over 'freedom of speech," " Schroeder argued, "was a demand that speakers might be free from ... subsequent punishment as well as previous restraint, ... and it was that controversy which the framers of our constitutions intended to decide for all time."303

Cooley used even more vivid language than Schroeder to condemn the judicial adoption of Blackstone: "liberty of the press might be rendered a mockery and a delusion, and the phrase itself a byword, if, while every man was at liberty to publish what he pleased, the public authorities might nevertheless punish him for harmless publications." ${ }^{304}$ The First Amendment guarantee, Cooley maintained, provides "complete immunity from legal censure and punishment" for all publications that are "not harmful" according to the standards of the common law. ${ }^{305}$

Pound and Schofield also criticized Blackstone's definition of free speech as an inflexible standard that prohibits too much as well as prevents too little. According to Pound, if the legislature could impose subsequent liability for any publication, "the result may easily be to effectually prevent indirectly and so establish a censorship and evade the guarantee." ${ }^{06}$ Similarly, Schofield reiterated that "if liberty of the press in the First Amendment means anything it legalizes published truth on all matters of public concern." ${ }^{307}$ Yet Pound rejected the argument that the constitutional guarantee "absolutely precludes an injunction against speaking and writing under any circumstances." Such a prohibition, he pointed out, would mean that "the constitution would forbid administrative prevention of false labels under a pure food law." ${ }^{08}$ Schofield also described as "untenable" deci-

302. Id. at 83 .

303. Schroeder-Unabridged "Freedom of Speech," supra note 260, at 41 . If the framers intended the First Amendment to prohibit only prior restraints, Schroeder argued, "the easiest way would have been to have had the Constitution say, "No censor shall ever be appointed,' or 'No previous restraints shall be put upon speech or press." 'T. SCHROEDER, The Historical Interpretation of "Freedom of Speech and of the Press," in "OBscene" Literature and Constitutional Law 206, 210 (1911) [hercinafter cited as Schroeder-Historical Interpretation].

304. T. Cooley, supra note 236, at 604 .

305. Id. at 605 .

306. Pound-Equitable Relief, supra note 239, at 651.

307. Schofield, supra note 238 , at 110 .

308. Pound-Equitable Relief, supra note 239, at 654. Pound identified four kinds of speech and writing for which subsequent liability had traditionally been imposed: picket. ing and other "intimidations," "immoral or indecent" matter, contempts interfering with justice, and material "dangerous to the conduct of military operations in time of war." 
sions that refused to issue injunctions against threatened union activity or defamatory falsehoods solely because the courts assumed that any prior restraint on publications violates the First Amendment. ${ }^{300}$

\section{E. The Limits of Protected Speech}

In addition to their uniform rejection of Blackstone and their common emphasis on the importance of protecting communication on matters of public concern, these scholars analyzed the boundaries of free speech. Freund and Schroeder gave close attention to this crucial issue, and other scholars addressed it in less specific terms.

\section{The Direct Incitement Test}

In an unusually detailed analysis that substantially foreshadorved Hand's decision in Masses Publishing Co., ${ }^{310}$ as well as his own subsequent criticism of Holmes' opinion in Debs v. United States, ${ }^{311}$ Freund suggested direct incitement to crime and violence as the point at which speech becomes illegal. "Agitation" is legal; "incitement" is not. As Freund summarized the crux of his argument:

By the principles of the common law, the procurement of crime is in itself a criminal act, and a conspiracy to commit a crime is criminal though the end is never accomplished or even undertaken. The prohibition of acts punishable at common law is of course within the constitutional power of the state governments. Therefore a statute may validly forbid all speaking and writing the object of which is to incite directly to the commission of violence and crime. ${ }^{312}$

On the other hand, Freund considered it "contrary to constitutional liberty in a free state to exercise compulsory control over public opinion and agitation, which refrains from the practice or incitement of violence and from injury to private rights." ${ }^{13}$

$I d$. at 651-53. Pound asserted that the difference between punishing these publications and enjoining them "is not very substantial." Id. at 653-54. To allow one type of restraint but not the other, he concluded, makes the guarantee of free speech "mercly formal." Id. at 654 .

309. Schofield, supra note 238, at 105 n.1, 106 n.1. Schofield added that statutes or municipal ordinances could constitutionally require prior censorship of motion pictures. If the censors became "too officious" and "abridge[d] the freedom of the press under the guise of guarding the public morals and promoting the general welfare," courts could correct these invasions. $I d$. at 83 .

310. 244 F. 535 (S.D.N.Y.), rev'd, 246 F. 24 (2d Cir. 1917); see note 415 infra.

311. Freund, The Debs Case and Freedom of Speech, 19 New Republic 13 (1919), reprinted in 40 U. CHI. L. REv. 239 (1973).

312. E. FREUND, supra note 28, at 510.

313. Id. at 10. 
Freund recognized the difficulty in refining the meaning of incitement, and attempted further clarification by applying it to "anarchistic propaganda." 314 He defined incitement to include the "glorification" of previous crimes, and words not addressed to or aimed at a specific person. But Freund did not view an assertion that crime could be justified under certain stated conditions as an incitement. ${ }^{315}$ Also, just as religious freedom "would have no meaning without the liberty of attacking all religion, so the freedom of political discussion is merely a phrase if it must stop short of questioning the fundamental ideas of politics, law and government."316 Statements opposing all government and arguing that its overthrow "cannot be accomplished otherwise than by force" are therefore constitutional. In fact, Freund concluded that "it is impossible to strike at anarchism as a doctrine without jeopardising valuable constitutional rights." Not surprisingly, he considered unconstitutional many of the criminal-anarchy laws enacted after the McKinley assassination. ${ }^{317}$

Freund also repudiated the bad tendency theory as a test of incitement, even if the speech appeals to emotion rather than to reason. ${ }^{318}$ "It is of the essence of political liberty," he argued, "that it may create disaffection or other inconvenience to the existing government, otherwise there would be no merit in tolerating it."310 In response to the argument that such appeals may encourage disorder and even violence, he pointed out that "this was always the plea upon which political agitation was formerly suppressed." Moreover, Freund maintained that the commission of a crime by an adherent of a doctrine does not necessarily make an advocate of that doctrine guilty of incitement. He believed that underlying "morbid brooding" over social conditions, rather than speech, is frequently responsible for criminal conduct by anarchists. ${ }^{320}$

Although neither Cooley nor Schofield set forth or elaborated as precise a standard as direct incitement, their writings lent implicit support to Freund's more developed position. Cooley's treatise, ${ }^{321}$

314. Id. at 510 .

315. Id. at 511 .

316. Id. at 509 .

317. Id. at 513. Freund did not, however, find constitutional problems in the immigration statute sustained by the Supreme Court in Turner v. Williams, 194 U.S. 279 (1901), because it did not "restrain the freedom of speech of anarchists residing in the country." E. FreUND, supra note 28 , at 512.

318. Id. at 511 .

319. Id, at $\mathbf{5 1 0 .}$

320. Id. at 511 .

32I. T. Coolex, supra note 236. 
known principally as a legal defense of laissez-faire capitalism, ${ }^{322}$ advocated broad protection for political expression under the First Amendment. Cooley would punish criticisms of government only "when they are made in furtherance of conspiracy with the evident intent and purpose to excite rebellion and civil war." 323 All other political speech is free under the Constitution, "however sharp, unreasonable, and intemperate it might be." ${ }^{24}$ Cooley justified this position by a frank acknowledgment of social and economic differences. He maintained that classes excluded from participating in government are often the most vigorous in criticizing it. Judges and juries, Cooley observed, generally belong "to the very classes who have established the exclusion" under attack, and will have "preconceived" views that the criticism is unreasonable. Further, they can only evaluate it after "the heat of the occasion has passed away" and therefore cannot appreciate the magnitude of the evil the critic perceived. The danger of repression, Cooley added, is increased "in times of high party excitement." For all these reasons, he reiterated, even "violent discussion" of public affairs beyond "all the proper bounds of moderation" is protected by the First Amendment. ${ }^{325}$

Schofield also implied that speech becomes subject to punishment only when it advises illegal action. He argued that publications, like other "overt acts," are illegal if "against peace and good order." But consistent with his rejection of Blackstone and the crime of seditious libel, he emphasized that publications are not illegal "simply because of their supposed bad tendency as opinion-makers." ${ }^{26}$ Schofield did not set forth any standard for determining when speech does violate "peace and good order"; however, he saw no constitutional objection to statutes punishing anarchists for teaching, advising, or advocating "the murder of public officers, riot, and arson,"327 or "the duty of killing any officer of the United States."32s

322. As the title of his treatise indicates, Cooley stressed the limitations of government power. His treatise, first published in 1868 and reissued in seven later editions through 1927, achieved "unprecedented popularity" and "surpass[ed] even those of Kent and Story" in prestige and authority." C. JAcoBs, L.Aw WRITERs AND THE Courrs 29 (1954). It became "the most fecund source of laissez faire constitutional principles available during the period." Id. at 30. Jacobs acknowledges that Cooley himsclf may not have intended or anticipated the "capitalistic orientation" conservative lawyers and judges extracted from his treatise, but it appears that Cooley easily acquiesced in this popular interpretation. $I d$.

323. T. Coolex, supra note 236 , at 613 (footnote omitted).

324. Id. at 615 .

325. Id. at 614 .

326. Schofield, supra note 238, at 78 .

327. Id. at 88 .

328. Id. 
Because Schofield examined the content of speech rather than its tendency and acknowledged the constitutionality of statutes that punish the advocacy of crime, his approach suggested the distinction between agitation and incitement proposed more explicitly by Freund. Moreover, foreshadowing one of the major subjects of debate among lawyers and judges during the Espionage Act litigation, Schofield warned that giving a jury a greater role in determining the legality of speech "does not necessarily make for freedom of public discussion of matters of public concern, either in normal times or in excited times, especially when the subject is politics, religion, a literary or scientific work, or a work of art." 329

\section{Pound's Balancing Test}

Although Pound favored greater protection for speech than some contemporary courts provided, his interpretation of the First Amendment allowed less leeway than Freund's incitement standard. Pound favored an explicit balancing test weighing the "individual interest in free belief and opinion" against the "social interest in the security of social institutions." "${ }^{330} \mathrm{He}$ maintained that the law can only punish action and cannot reach "subjective states in and of themselves." Yet, by defining "manifestations of belief" as actions ${ }^{331}$ and by favoring their repression if they "threaten to overturn vital social institutions or to weaken the power of the state," ${ }^{332}$ Pound seemed willing to weigh the bad tendency of speech in determining its legality. Based on these considerations, for example, he justified the federal suppression of antiwar statements during the Civil War. ${ }^{333}$

Pound also maintained that the nature of the audience should be considered in the balance. The same social and economic differences that led Cooley to propose wide latitude for free speech were, in Pound's opinion, grounds for additional restrictions. Pound was particularly concerned about "the danger of mobs, which are controlled by suggestion," in the large and congested cities populated by the poor and ignorant. As a result, he approved restrictions on the time and place of political speech in order to avoid "grave danger of violence and disorder." 334

329. Id. at 98-99.

330. Pound-Personality, supra note 239 , at 454 .

331. Id. at 456 .

332. Id. at 454 .

333. Id. at 456.

334. Id. at 455. Pound listed a number of cases that restricted free speech, identified the social interest at stake, and, without attempting to make any distinctions among the 


\section{Schroeder's Test of Actual Injury}

Predictably, Theodore Schroeder's interpretation of the limits of free speech was the most libertarian of the prewar period. Throughout his voluminous writings, Schroeder emphasized and reiterated his principal argument: all speech, including the advocacy of criminal conduct, is protected by the First Amendment unless it directly results in an actual and material injury designated by the legislature as a crime. In that event, the speaker "is to be punished for the subsequent crime and his intentional participation in it, and not merely for his utterances, as such." ${ }^{335}$ Thus, a speaker could be punished as an accessory to murder, arson, or any other crime that had already occurred, and his speech could be used as evidence of his responsibility for the resulting injury. ${ }^{336}$ But even the advocacy of treason and assassination is protected under the First Amendment "so long as no one was actually injured thereby." 337

Schroeder praised the framers for making "no exception for any particular class of intellectual 'evils," "338 a decision recognizing that once one subject is suppressed all speech is threatened. ${ }^{339} \mathrm{He}$ attacked the courts, as Justice Harlan criticized his colleagues in Patterson, for restricting freedom of discussion to "whatever a legislature of mediocre attainments" considers in the "interest of the public

social and individual interests implicated or the dangers threatened, apparently approved the results in all of the cases cited. Pound did not differentiate among Most's publications, a public meeting led by a socialist, the distribution of handbills causing a threat of fire, newspaper reports of crime, and Salvation Army parades. Id. at 455 n.99.

335. Schroeder-Advocacy of Crime, supra note 278, at 34. See T. Schroeder, Conceming the Meaning of "Freedom of the Press," in "Obscene" Literature and Constitutional LAw 142, 151 (1911) [hereinafter cited as Schroeder-Meaning of "Freedom of the Press"]; Schroeder-Constitutional Construction, supra note 254, at 91; T. Schroeder, "Due Process of Law" in Relation to Statutory Uncertainty and Constructive Offenses, Part I, in "OBSCENE" Literature AND Constitutional LAw 343, 350-51 (1911) [hereinafter cited as Schroeder-Due Process, Part I]; Schroeder-Historical Interpretation, supra note 303, at 230.

To bolster his argument, Schroeder cited Thomas Jefferson's statement, embodied in the Virginia Act of Toleration and "[e]ndorsed as authoritative" by the United States Supreme Court in Reynolds $v$. United States: " 'it is time enough for the rightful purposes of civil government for its officers to interfere when principles break out into overt acts against pcace and good order." 98 U.S. 145, 163 (1878), quoted in Schroeder-Constitutional Construction, supra note 254 , at 89 , and T. Schroeder, The Meaning of Free SPEECH (For PACIFISTs) 13 (1917). Jefferson and Reynolds were also invoked by the appellant in Davis v. Beason, 133 U.S. 333 (1890). See note 112 supra.

336. Schroeder-Meaning of "Freedom of the Press," supra note 335, at 151; Schroedcr -Unabridged "Freedom of Speech," supra note 260, at 40.

337. Schroeder-Unabridged "Freedom of Speech" supra note 260 , at 41 .

338. T. SCHROEDER, Liberal Opponents and Conservative Friends of Unabridged Free Speech, in FreE SPEech For RAdicals 54, 63 (enl. ed. 1916) [hereinafter cited as Schroeder -Liberal Opponents and Conservative Friends].

339. Id. at 64 . 
welfare." 340 Indeed, Schroeder maintained that this limitation on free speech would make inexplicable the enactment of the First Amendment "because no other opinions than such as had been deemed contrary to the public welfare ever had been suppressed anywhere." Schroeder pointed out that the language of the First Amendment makes no exception for "the interest of the public welfare," and insisted that courts could not properly read such a restriction into it. ${ }^{341}$

At times, Schroeder backed off from this strict standard, which precluded the punishment of speech unless a criminal act had occurred. Speech that directly leads to an attempt, he occasionally conceded, might constitutionally be punished even if the completed crime never takes place. ${ }^{342}$ Moreover, Schroeder seemed to give additional ground when he acknowledged the possibility that a legislature, consistent with the First Amendment, might "regulate the imminent danger of actual and material injury." 343 Speech could conceivably create "imminent danger" without producing an actual attempt.

Yet Schroeder made clear that this language, which bears a linguistic similarity to Holmes' "clear and present danger" phrase in Schenck, should not be considered a restatement of the bad tendency test that Schroeder repeatedly rejected. ${ }^{344}$ The "imminent danger," Schroeder stressed, can only be ascertained according to "known physical laws." 345 Schroeder did not provide concrete examples of how such determinations were to be made, but he asserted that "no form of speech (including printing) can be penalized merely on the basis of a jury speculation about the prospective psychological tendency of the idea upon a hypothetical future reader." ${ }^{340} \mathrm{He}$ specifically criti-

340. Schroeder-Historical Interpretation, supra note 303, at 212; see Patterson v. Colo. rado, 205 U.S. 454, 465 (1907) (Harlan, J., dissenting); pp. 540-41 supra.

341. Schroeder $\rightarrow$ Historical Interpretation, supra note 303 , at 210.

342. Schrocder-Constitutional Construction, supra note 254, at 100; Schroeder-Historical Interpretation, supra note 303, at 207.

343. Schroeder-Constitutional Construction, supra note 254, at 113; see SchroederHistorical Interpretation, supra note 303 , at 238.

344. Sec, e.g., T. SChroeder, "Due Process of Law" in Relation to Statutory Uncertainty and Constructive Offenses, Part II, in "OBSCENE" Literature and Constitutional L1w 355, 362-63 (1911) [hereinafter cited as Schroeder-Due Process, Part II]; SchroederUnabridged "Frecdom of Speech," supra note 260, at 42.

315. Schroeder-Constitutional Construction, supra note 254, at 113; see SchroederHistarical Interpietation, supra note 303, at 238.

316. Schroeder-Constitutional Construction, supra note 254, at 93; see SchroederDue Process, Part I, supra note 335, at 350-51; Sclroeder-Due Process, Part II, supra note 344, at 362. The Articles of Incorporation of the Free Speech League stated that one of the League's principal objects was "to preclude the punishment of any mere psycholrigical offense." T. SCHROEdER, FREE SPEECH FOR Radicals, supra note 241 (frontispiece).

Perhaps in response to the hostile judicial treatment of First Amendment claims, Schroeder also used the uncertainty inherent in psychological speculation to allege a connection 
cized the Hicklin test of obscenity on this ground. ${ }^{347}$ For similar reasons, Schroeder, like Pound, argued that the state of mind of a speaker can provide no basis for forfeiting the protection of the First Amendment. Leaving such a subjective determination to legislative discretion or judicial speculation, he feared, would undermine the Amendment's guarantees. ${ }^{348}$

\section{The Benefits of Libertarian Standards}

Freund, Cooley, and Schroeder all stressed that libertarian standards for speech actually reduced the danger of violence and crime. Freund tried to disarm potential critics by claiming that his position "is based not upon generosity, but on sound policy." He asserted that discussion of ideas "alone can render them harmless and remove the excuse for illegality by giving hope of their realisation by lawful means." 349 As "consolation" to those favoring greater restrictions on free speech, Cooley, like Freund, reasoned that any evil likely to result from his protective standard would "probably be less, and its correction by public sentiment more speedy, than if the terrors of the law were brought to bear to prevent the discussion." 350 Schroeder also tried to assure his readers that, by safeguarding free speech, society protects the public welfare. Invoking the authority of "conservative friends of free speech" to taunt "liberal opponents," 351 Schroeder pointed out that " $[t]$ he thought that the greatest liberty of speech, even as to 'violent' language, is the best way to avert actual

between First Amendment and other constitutional prohibitions. As a check against "arbitrary power," Schroeder pointed out, the due process clauses of the Fifth and Fourteenth Amendments "requir[e] absolute certainty in the criteria of guilt." He maintained that his conception of the First Amendment is the only way to "coordinate" freedom of expression with due process of law. Schroeder-Constitutional Construction, supra note 254, at 92-93; see Schroeder-Due Pracess, Part II, supra note 344, at 359.60. Schroeder further argued that uncertain tests for defining guilt in free speech cases, by "delegating to the courts a seeming authority for creating ex post facto standards of judgment at the trial of the accused," violate the Constitution. Schroeder-Constitutional Construction, supra note 254, at 96 . Uncertainty, moreover, is inconsistent with the Sixth Amendment's assurance that the defendant in all criminal prosecutions " shall be informed of the nature and cause of the accusation." "Id. at 95-96. These arguments found expression in Roe's brief in Fox. See Brief for Plaintiff-in-Error, supra note 91, at 15-17; pp. 534-35 \& note 91 supra.

347. T. Schroeder, The Etiology and Development of Our Censorship of Sex-Literature, in “Obscene” Literature and Constitutional Law 42, 55 (1911).

348. Schroeder-Liberal Opponents and Conservative Friends, supra note 333, at 67-68.

349. E. Freund, supra note 28 , at 510 .

350. T. CoOLEY, supra note 236 , at 614 .

351. Schroeder-Liberal Opponents and Conservalive Friends, supra note 338, at 51-72. "Conservative friends" included Lord Macaulay and Sir Leslie Stephen; "liberal opponents" included the editors of various liberal journals such as The Truth Seeker, The Humanitarian Review, and The Public. 
violence is not original with me." 352 He maintained that the highest frequency of political assassination occurs in Tsarist Russia, while the smallest number of violent incidents takes place in England, which "probably has the greatest freedom of speech of any country in the world." ${ }^{353}$ Schroeder also referred to newspaper reports to support his claim that violence in the United States generally followed the repression, and not the exercise, of free speech..$^{354}$

\section{F. The Heritage of Prewar Scholarship}

The work of these five authors illustrates the chasm that existed before World War One between the world of legal scholarship and the judiciary. The restrictive results and the analytic poverty of the prewar decisions reflected the pervasive judicial hostility to the value of free speech. Those cases bear little resemblance to recent First Amendment adjudication. Much of the legal scholarship of that period, on the other hand, hardly seems the product of an earlier age. Scholars identified and addressed many of the issues that continue to generate judicial and scholarly commentary. From historical and functional analyses of the purposes of the First Amendment, they derived practical tests for determining its scope.

These prewar writings, generally ignored in contemporary judicial decisions, are today largely forgotten. Chafee is now considered the seminal scholar of the First Amendment. ${ }^{355}$ Chafee himself, however, relied on his scholarly predecessors, and Holmes and Brandeis in turn relied on Chafee in developing a libertarian tradition in their dissenting opinions in the 1920s. As a result, these prewar scholars exerted belated yet significant influence on the development of First Amendment theory in a more receptive era.

III. The Role of the Prewar Tradition in the Early Development of Modern First Amendment Doctrine

The neglect by authors since Chafee of the prewar judicial and scholarly treatment of free speech issues has created significant gaps in our understanding of the early development of modern First

352. T. Schroeder, The Lawless Suppression of Free Speech in New York, in FrEc SPEECH FOR RADICALS 11, 20 (enl. ed. 1916).

353. Id. at 13.

354. Id. at 19.20; see p. 564 supra (Pound asserts that individual will fight if specch repressed).

355. See Auerbach, The Patrician as Libertarian: Zechariah Chafee, Jr. and Freedom of Speech, 42 NEw ENG. Q. 511, 531 (1969); Prude, Portrait of a Civil Libertarian: The Faith and Fear of Zechariah Chafee, Jr., 60 J. AM. Hisr. 633, 655 (1973). 
Amendment doctrine. Justice Holmes' opinion in Schenck $v$. United States, ${ }^{356}$ an Espionage Act prosecution, has become the starting point for virtually all legal analysis of First Amendment adjudication in the Supreme Court. Scholars have pointed out that the phrase "clear and present danger" in Schenck, soon made popular by Chafee as a libertarian standard, has inherent limitations as an analytical tool for the protection of speech. ${ }^{357}$ Several have demonstrated that Holmes derived this language from his longstanding views on the common law of criminal attempts ${ }^{358}$ and have noticed that Holmes' opinion in Schenck did not differ appreciably from his restrictive prewar decisions in cases such as Davis v. Massachusetts, Patterson v. Colorado, and Fox $v$. Washington. ${ }^{350}$ Many scholars have also observed that Holmes' dissent in Abrams $v$. United States, ${ }^{360}$ and not his majority opinion in Schenck, marked the first time he advocated meaningful judicial protection for speech. ${ }^{\mathbf{3 6 1}}$

Although correct, these revisionist interpretations are incomplete. They challenge Chafee's understanding of Schenck, but still accept his position that no cases of significance preceded it. They therefore fail to recognize that most decisions during and after World War One, including Justice Holmes' opinions in Schenck, Frohwerk v. United States, ${ }^{362}$ and Debs v. United States, ${ }^{303}$ demonstrate the continuing influence of the prewar tradition of hostility to free speech.

356. 249 U.S. 47 (1919).

357. Corwin, Bowing Out "Clear and Present Danger," 27 Notre Dame Law. 325, 356 59 (1952); Linde, "Clear and Present Danger" Reexamined: Dissonance in the Brandenburg Concerto, 22 STAN. L. REv. 1163, 1174-82 (1970); Rogat, supra note 92, at 217; Wechsler, Symposium on Civil Liberties, 9 AM. L. SCH. REv. 881, 887 (1941), reprinted in SELECTED Essays on Constitutional LAw, 1938-1962, at 628, 634 (1963).

Recent legal scholarship has so heavily criticized Justice Holmes that his once unchallenged reputation as a civil libertarian has been replaced by a new orthodoxy cmphasizing his indifference or hostility to civil liberties, particularly before his dissent in Abrams v. United States, 250 U.S. 616, 624 (1919). White, The Rise and Fall of Justice Holmes, 39 U. CHI. L. Rev. 51 (1971), provides an overview of this transformation. See S. Konefsky, The Legacy of Hormes AND Brandeis I8I-202 (1956); Gunther, supra note *, at 720, 739; Ragan, Justice Oliver Wendell Holmes, Jr., Zechariah Chafee, Jr., and the Clear and Present Danger Test for Free Speech: The First Year, 1919, 58 J. AM. Hist. 24, 25-26, 37 (1971); Rogat, Mr. Justice Holmes: A Dissenting Opinion (pts. 1.2), 15 STaN. L. REv. 3, 254 (1962-1963).

358. Hall, The Substantive Law of Crimes-18s7-1936, 50 HARv. L. Rev. 616, 621 (1937);

Ragan, supra note 357, at 29-31; Rogat, supra note 92, at 215-17.

359. S. KonEFsKY, supra note 357 , at 185-93; Corwin, supra note 357 , at 326-29; sec pp. 533-36 supra.

360. 250 U.S. 616,624 (1919).

361. S. KONEFSKY, supra note 357, at 193; Gunther, supra note *, at 720, 741-43;

Kalven, supra note 24, at 238; Prude, supra note 355, at 640.

362. 249 U.S. 204 (1919).

363. 249 U.S. 211 (1919). 
Chafee's classic article, Freedom of Speech in War Time, ${ }^{364}$ was published between the Schenck and Abrams decisions. As part of his campaign to provide greater tolerance for free speech, he obscured the prewar cases while borrowing extensively from the prewar scholars. Through an ingenious but unsupportable construction of Holmes' Espionage Act decisions, Chafee also created the myth that Holmes intended the words "clear and present danger" in Schenck to be a libertarian principle of First Amendment adjudication. ${ }^{365}$ As Holmes, and especially Brandeis, rapidly became more sensitive to free speech concerns, they eagerly accepted and promoted the erroneous conclusions of Chafee's article. ${ }^{366}$

\section{A. The Selective Draft Law Cases}

Antiwar speeches and publications frequently prompted government prosecutions under the Selective Draft Law and the Espionage Act. Three Selective Draft Law decisions by the Supreme Court in 1918 carried on the prewar tradition of ignoring First Amendment issues. In these cases, antiwar speakers were convicted for inducing or conspiring to induce eligible persons not to register. ${ }^{367}$ The briefs of the defendants focused on the constitutionality of the draft law, on the adequacy of the indictments and the evidence, and on matters of criminal procedure. ${ }^{368}$ Yet they did not rely on the First Amendment, even though, as the brief for Emma Goldman and Alexander Berkman contended, a judge and a jury caught up in the "war hysteria at the time" had simply convicted two notorious anarchists for repeating the theories and beliefs on a public question that they

364. Chafee-Freedom of Speech in War Time, supra note 3. The June 1919 issue of the Harvard Law Review arrived at the Library of Congress on August 19, 1919.

365. Id. at 966-69. Chafee tempered his interpretation of Schenck somewhat by conceding that Holmes had not emphasized the social interest behind free speech and had given undue deference to perceived military needs. Id. at 968-69.

366. A separate article, which $I$ intend to publish, is necessary to provide a complete account of the transformation in the approach of Holmes and Brandeis to First Amendment issues, and of the related transformation of "clear and present danger" from its origins in the common law of criminal attempts to its status as a libertarian standard of constitutional interpretation. These transformations are important in the context of this article because they complete the story of the prewar tradition and help explain why that tradition has now been forgotten.

367. Ruthenberg v. United States, 245 U.S. 480 (1918) (inducement); Kramer v. United States, 245 U.S. 478 (1918) (conspiracy); Goldman v. United States, 245 U.S. 474 (1918) (conspiracy). The Selective Draft Law dealt with the mechanics of raising an army. See Act of May 18, 1917, ch. 15, 40 Stat. 76 (expired 1919). The prohibitions against inducement and conspiracy were contained in the contemporary criminal code.

368. Brief for Plaintiffs in Error, Ruthenberg v. United States, 245 U.S. 480 (1918); Brief on Behalf of the Plaintiffs-in-Error, Goldman v. United States, 245 U.S. 474 (1918) [hereinafter cited as Goldman Brief]. 
had expressed during the past twenty years. ${ }^{369}$ Chief Justice White's opinions affirming the convictions at no point referred to free speech..$^{370}$

\section{B. The Espionage Act Cases}

A year later, the Supreme Court considered very similar issues in its first Espionage Act ${ }^{371}$ decisions: Schenck v. United States, ${ }^{372}$ Sugarman v. United States, ${ }^{373}$ Frohwerk v. United States, ${ }^{374}$ and Debs v. United States. ${ }^{375}$ The government charged that antiwar articles and speeches by the defendants caused or attempted to cause insubordination in the armed forces or obstruction of recruitment or enlistment. All of the briefs, unlike those filed just a year earlier in the Selective Draft Law cases, included First Amendment challenges to the convictions. Probably because the prosecution and conviction of Debs, the most prominent socialist in the country, had aroused widespread popular attention, ${ }^{376}$ the briefs in his case provided the fullest discussion of freedom of speech. ${ }^{377}$

\section{Defendants' First Amendment Arguments}

The major First Amendment issue posed by these Espionage Act cases involved two related disputes: whether the statute made speech punishable for its bad tendency and whether this question is of constitutional significance. The main brief for Debs criticized reliance on the "indirect effect" or the "reasonable and natural consequences"

369. Goldman Brief, supra note 368 , at 18-20.

370. Ruthenberg v. United States, 245 U.S. 480 (1918); Kramex v. United States, 245 U.S. 478 (1918); Goldman v. United States, 245 U.S. 474 (1918).

371. The Act provided that

whoever, when the United States is at war, shall willfully cause or attempt to cause insubordination, disloyalty, mutiny, or refusal of duty, in the military or naval forces of the United States, or shall willfully obstruct the recruiting or enlistment service of the United States, to the injury of the service or of the United States, shall be punished by a fine of not more than $\$ 10,000$ or imprisonment for not more than twenty years, or both;

Act of June 15, 1917, ch. 30, tit. 1, $\$ 3,40$ Stat. 217 (current version at 18 U.S.C. $\$ 2388$ (a) (1976)). It also provided the same penalties for a conspiracy to violate that section. Id. $\$ 4$ (current version at 18 U.S.C. $\$ 2388$ (b) (1976)).

372. 249 U.S. 47 (1919).

373. 249 U.S. 182 (1919).

374. 249 U.S. 204 (1919).

375. 249 U.S. 211 (1919).

376. See R. Ginger, The Bending Cross 353-84 (1949) (biography of Debs).

377. Alfred Bettman and John Lord O'Brian, who wrote the government's briefs in all four of the Espionage Act cases, and Seymour Stedman, the lead attorney for Sugarman and Debs, devoted their main efforts to the Debs case. In addition, Gilbert Roe of the Free Speech League chose Debs as the case in which to file an amicus brief. See notes $378,379,385$ infra. 
of speech as a basis for finding specific criminal intent under the Espionage Act. It warned that such reliance would confine antiwar politics to times of peace, restrict discussion of this vital subject of public policy to high government officials, and create a "caricature" of the First Amendment. ${ }^{378}$ Gilbert Roe's amicus brief for Debs, consistent with the views of the Free Speech League and Roe's prewar activity in free speech cases, underlined the danger of the bad tendency theory, which he contended was unconstitutional. The conviction of Debs, and the similar plight of many other Espionage Act defendants in federal district courts, demonstrated to Roe that a judge or jury could punish a speaker for a speech or article "in the absence of any evidence that it produced a particular effect" simply because they believed "it would have a tendency to produce the results complained of." If the Court upheld this approach in Debs, Roe pointed out, Congress could proscribe the use of unidentified language subsequently found to have had a tendency to cause a prohibited effect, or specific language deemed in itself to have a bad tendency. ${ }^{370}$

In addition to criticizing the bad tendency test, the briefs for the defendants in the Espionage Act cases raised broader policy questions concerning freedom of speech and relied on the treatises of Cooley and Freund. Schenck's attorneys, citing Cooley as authority, maintained that the First Amendment protects free discussion of public affairs, including the "scrutiny and condemnation" of those in power. "Absolutely unlimited discussion," they asserted, spreads the truth and permits citizens to exercise their rights intelligently. ${ }^{380}$ They stressed, ${ }^{381}$ as did Stedman in his Debs brief, ${ }^{382}$ the importance of allowing the free expression of minority views. Several of the briefs claimed that free speech encompasses more than the prohibition against

378. Brief for Plaintiff in Error at 84, Debs v. United States, 249 U.S. 211 (1919) [hereinafter cited as Stedman Brief for Debs].

379. Brief of Gilbert E. Roe, as Amicus Curiae, at 16, Debs v. United States, 249 U.S. 211 (1919) [hercinafter cited as Roe Amicus Brief for Debs].

Linde, supra note 357 , at 1171 , and Rogat, supra note 92 , at 217 , discuss the difference betwcen these two forms of legislation. The Supreme Court addressed this distinction in Gitlow v. New York, 268 U.S. 652, 654, 670-71 (1925) (upholding statute prohibiting "[a]klvocacy of criminal anarchy" and distinguishing Espionage Act); cf. Whitney v. California, 274 U.S. 357, 378-79 (1927) (Brandeis, J., concurring) (statute creates only rebuttable presumption that specified utterances may constitutionally be punished).

380. Brief of Plaintiffs in Error at 6-7, Schenck v. United States, 249 U.S. 47 (1919) [hereinafter cited as Brief for Schenck].

381. Id. at 8 (importance of "honest criticism of the majority by the minority").

382. Stcdman Bricf for Debs, supra note 378, at 62 ("degree of tolerance of minority sentiments" is test of political freedom). 
prior restraints ${ }^{383}$ and argued, referring to Cooley, Freund, and the experience under the Sedition Act of 1798, that the First Amendment made the crime of seditious libel obsolete. ${ }^{384}$

\section{The Government's Response}

The government relied on the prewar judicial tradition in its reply briefs. It argued that the bad tendency test was necessary to save "the Nation" from being "powerless to punish any incitement to lawlessness, however intentional and however effective, so long as it is concealed in veiled, indirect, or rhetorical language." ${ }^{855}$ After pointing out that Blackstone's position constituted the prevailing interpretation of the First Amendment and had been sustained by the Supreme Court in Patterson v. Colorado, the government conceded that this definition might be unnecessarily restrictive. ${ }^{386}$ It acknowledged that "[s]ome authorities" maintain that the First Amendment protects all speech not considered illegal at common law. ${ }^{387}$ Yet the government, ignoring the references in the defendants' briefs, incorrectly stated that "all authorities" recognize seditious speech as among the harmful utterances punishable at common law and therefore beyond the protection of the First Amendment. 388 It also argued that the "right of self-preservation," identified by the Supreme Court in Turner $v$. Williams, supported the validity of the Espionage Act. ${ }^{389}$

\section{The Unanimous Opinions by Holmes and Brandeis}

Holmes or Brandeis wrote a unanimous opinion in all four of the first group of Espionage Act decisions, affirming the convictions and

383. Brief for Schenck, supra note 380, at 6; Stedman Brief for Debs, supra note 378, at 86; Roe Amicus Brief for Debs, supra note 379, at 23-26. Roe observed that Professor St. George Tucker, in his 1803 American edition of Blackstone's Commentaries, stated that freedom of the press requires "an exemption, not only from the previous inspection of licencers, but from the subsequent penalty of laws." Id. at 44 (quoting Tucker, Appendix to Volutne First. Part Second., Note $G$ at 20, to W. Blackstone, Commentaries (S. Tucker ed. 1803)) (emphasis added by Roe).

384. Statement, Brief and Argument for Plaintiff in Error by Frans E. Lindquist at 29-31, Frohwerk v. United States, 249 U.S. 204 (1919); Stedman Brief for Debs, supra note 378, at 74-76, 85; Roe Amicus Brief for Debs, supra note 379, at 32-42.

385. Brief for the United States at 72, Debs v. United States, 249 U.S. 211 (1919) [hereinafter cited as Brief for United States in Debs]; see Brief for the United States, in Reply to Brief of Gilbert E. Roe, as Amicus Curiae, at 2-3, Debs v. United States, 249 U.S. 211 (1919) [hereinafter cited as Reply to Roe].

386. Brief for United States in Debs, supra note 385 , at 80.81 . The brief quoted at length, $i d$. at 84-88, from Pound's specific discussion of prior restraints and his general treatment of free speech in Pound-Equitable Relief, supra note 239, at 650-54.

387. Brief for United States in Debs, supra note 385 , at 81 . The government quoted Robertson v. Baldwin, 165 U.S. 275, 281 (1897), see pp. 539.40 supra. Brief for United States in Debs, supra note 385, at 70; Reply to Roe, supra note 385, at 17 .

388. Brief for United States in Debs, supra note 385 , at 81 .

389. Id. at 90; see p. 538 supra. 
rejecting the defendants' First Amendment claims. Brandeis accepted the government's suggestion to dismiss Sugarman for lack of jurisdiction because the case did not present any substantial constitutional question..$^{390}$ He thereby neglected the underlying First Amendment issues, ${ }^{391}$ as did so many Supreme Court decisions before the war.

Holmes devoted only slightly more attention to the First Amendment in Schenck, Frohwerk, and Debs. He briefly referred to it in one paragraph in Schenck, ${ }^{392}$ and then relied on Schenck in dismissing First Amendment claims in Frohwerk ${ }^{393}$ and Debs. ${ }^{304}$ He never mentioned the treatises of Cooley and Freund, authorities stressed in the main brief for Debs and cited in several of the other briefs in the Espionage Act cases. Instead, Holmes focused on questions of criminal law, ${ }^{395}$ and in all three cases, using an analysis bearing a remarkable similarity to his prewar decisions, predicated punishment on the tendency of speech. ${ }^{396}$

Holmes characterized Schenck's position as contending that the First Amendment protects the distribution of antiwar circulars even if they have the "tendency" to obstruct recruitment. ${ }^{397}$ Holmes disagreed: "If the act, (speaking, or circulating a paper,) its tendency and the intent with which it is done are the same, we perceive no ground for saying that success alone warrants making the act a crime." 398 In Frohwerk, Holmes found a conviction justified by possible innu-

390. 249 U.S. 182,185 (1919).

391. Brandeis decided to dismiss Sugarman for reasons different from those that the government suggested, thus further obscuring the free speech claim. Compare Brief for the United States at 36-37 (punishment of attempts, through speech, to violate valid statute is necessarily constitutional) with 249 U.S. at 184-85 (judge's instructions had "clearly cmbodied" substance of defendant's requests regarding constitutional rights and free speech). Nor did Brandeis respond to any of the extensive constitutional arguments in Stedman's brief for Debs, even though Stedman concluded his brief for Sugarman by referring explicitly to them. See Brief of Plaintiff in Frror at 21.

392. 249 U.S. $47,51-52$ (1919).

393. 249 U.S. 204,206 (1919).

391. 249 U.S. 211,215 (1919).

395. Kalven observed that Holmes considered Debs "a routine criminal appeal." Kalven, supra note 24 , at 238 . Gunther would apply this,comment "to the entire spring 1919 trilogy." Gunther, supra note *, at 736 n.83.

396. "In the final analysis," Corwin pointed out, "the doctrine announced in the Schench case is indistinguishable from that presented in Fox." Corwin, supra note 357, at 329 .

397. 249 U.S. 47,51 (1919).

398. Id. at 52. Holmes, citing Gompers v. Bucks Stove \& Range Co., 221 U.S. 418 (1911), see pp. 531-32 supra, stressed that free speech does not even "protect a man from an injunction against uttering words that may have all the effect of force." 249 U.S. at 52. However, he did retreat from his position in Patterson. "It may well be," he acknowledged, "that the prohibition of laws abridging the freedom of speech is not confined to previous restraints, although to prevent them may have been the main purpase, as intimated in Patterson." Id. at 51-52; see pp. 533-34 supra. 
endo and gave metaphorical expression to the bad tendency test by maintaining that "a little breath would be enough to kindle a flame." 390 Sustaining the conviction in Debs, Holmes stated that the jury could have found that "the opposition was so expressed that its natural and intended effect would be to obstruct recruiting." 400 According to Holmes, the principle that the tendency of words, combined with other evidence, indicates the speaker's intent "is too well established and too manifestly good sense to need citation of the books." ${ }^{401}$ Holmes' initial Espionage Act opinions, therefore, extended the prewar tradition of relying on the bad tendency of speech to deny free speech claims.

\section{Zechariah Chafee, Jr., and the Selective Use of the Prewar Tradition}

The publication of Chafee's Freedom of Speech in War Time in the June 1919 issue of the Harvard Law Review ${ }^{402}$ provided the essential link between the prewar scholarship and the postwar judicial tradition initiated by Justices Holmes and Brandeis soon after this article appeared. Chafee indicated that the courts had not previously confronted free speech issues in any significant way, but he did incorporate into his article, often by explicit reference, many of the major principles that Cooley, Freund, Pound, Schofield, and Schroeder had developed at length before the war. Holmes and Brandeis, who began to dissent in First Amendment cases only months later, turned to Chafee in much the same manner as Chafee had relied on his scholarly predecessors. Thus the theoretical foundations for modern First Amendment doctrine, despite the overwhelming judicial tradition of hostility to free speech, emerged from the thinking of the prewar scholars, who were generally unheeded and perhaps not even noticed by contemporary judges.

\section{Chafee's Reliance on the Prewar Scholars}

Consistent with the emphasis of the prewar scholarship and in language reminiscent of Schofield, Chafee asserted that the First Amendment "is a declaration of national policy in favor of the public dis-

399. 249 U.S. 204, 209 (1919). In Frohwerk, Holmes cited Robertson v. Baldwin, 165 U.S. 275 (1897), see pp. 539-40 supra, for the proposition that the First Amendment was "not . . intended to give immunity for every possible use of language." 249 U.S. at 206. 400. 249 U.S. 211, 214-15 (1919).

401. Id. at 216.

402. Chafee-Freedom of Speech in War Time, supra note 3. 
cussion of all public questions." ${ }^{\text {"403 }}$ In a paragraph that he privately described as "key," 404 Chafee explained that " $[t]$ he true meaning of freedom of speech" is to foster society's interest in "the discovery and spread of truth on subjects of general concern." 405

Chafee followed the example of his scholarly predecessors by citing the history of the First Amendment to support his understanding of its purpose. He observed that Blackstone was "not interpreting a constitution but trying to state the English law of his time," which itself had changed after the enactment of Fox's Libel Act in 1792.406 He quoted at length from Cooley's criticisms of Blackstone and called them "unanswerable." 407 Without direct citation, Chafee also accepted the view of Pound and Schofield that Blackstone at times went "altogether too far in restricting state action" and at other times gave "very inadequate protection to the freedom of expression." 408 Chafee, as had Cooley, Schofield, and Schroeder, concluded that the free speech clauses of the federal and state constitutions were designed to abolish the common-law crime of seditious libel. ${ }^{409}$ The Sedition Act of 1798, Chafee maintained, "revive[d]" this crime and "proved so disastrous" that no similar legislation was enacted during the next century. ${ }^{410}$ Writing also in the tradition of the prewar scholars, Chafee denounced the evils of the bad tendency test. After the abolition of cen-

403. Id. at 934. For Schofield's similar views, see Schofield, supra note 238, at 91, quoted at p. 563 supra.

401. Statement of Z. Chafee, Jr., about his work on Freedom of Speech (Zechariah Chafee, Jr., Papers, Box 29, Folder 22, Harvard Law School Library) [hereinafter cited as Chafee Statement]. Chafee repeated this paragraph from an earlier article in The New Republic, Chafee-Freedom of Speech, supra note 3, at 67, as he noted in his longer article, Chafee-Freedom of Speech in War Time, supra note 3, at $957 \mathrm{n} .80$.

405. Chafee-Freedom of Speech in War Time, supra note 3, at 956.

406. Id. at 939. Chafee also noted that Blackstone had been criticized as "an antirepublican lawyer" by one of his English contemporaries. Id. at 939 n.24 (citing Schofield, supra note 238, at 85); see note 299 supra (discussing Blackstone in historical context).

407. Chafee-Freedom of Speech in W' Th Time, supra note 3, at 940.

408. Id. at 939-40; see pp. 571-72 supra (discussing Pound and Schofield on Blackstone). Chafee, writing in the aftermath of the war, was able to provide a dramatic illustration of the practical inadequacy of the rigid application of Blackstone. "The prohibition of previous restraint," he pointed out, "would not allow the government to prevent a newspaper from publishing the sailing dates of transports or the number of troops in a sector." Chafee-Freedom of Speech in War Time, supra note 3, at 939. Chief Justice Hughes cited these examples as exceptions to the general prohibition against prior restraints. Near v. Minnesota, 283 U.S. 697, 716 (1931).

409. Chafee-Freedom of Speech in War Time, supra note 3, at 946-47; see id. at 946 (quoting Schofield's similar conclusion). Chafee, like most of the prewar scholars, did acknowledge "that certain forms of utterance, which have always been crimes or torts at common law, are not within the scope of the free speech clauses." Id. at 943. Yet he also agreed that "the meaning of the First Amendment did not crystallize in 1791." Id. at 954; see pp. 569-70 supra (discussing support by prewar scholars for expanding conception of free speech).

410. Chafee-Freedom of Speech in War Time, supra note 3, at 953. 
sorship, he pointed out, opponents of free speech joined to this test the doctrines of indirect causation and constructive intent. Under these doctrines "words can be punished for a supposed bad tendency long before there is any probability that they will break out into unlawful acts" and intent can be inferred "from the bad tendency of the words on the ground that a man is presumed to intend the consequences of his acts." 411 Drawing on the history of prosecutions for sedition in Great Britain and the United States during the late eighteenth century, Chafee concluded "that the most essential element of free speech is the rejection of bad tendency as the test of a criminal utterance." ${ }^{412}$ Chafee also observed, as had several scholars before the war, that transferring the determination of liability from judge to jury, the accomplishment of Fox's Libel Act, provides meaningful protection only for popular criticisms of government. ${ }^{413}$ Thus, for Chafee, the essential question was "not, who is judge of the criminality of an utterance, but what is the test of its criminality." 414

Chafee derived his test from an artful combination of Pound's balancing approach and the direct incitement standard employed by Hand in Masses Publishing Co.415 Citing Pound's earlier discussion, ${ }^{416}$ he identified individual and social interests in free speech as well as social interests in restricting speech to preserve public safety. Chafee also agreed with Pound that those interests must be balanced in order to define the boundary between protected and unlawful speech. ${ }^{417}$

411. Id. at 949 .

412. Id. at 953; see id. at 948 .

413. Id. at 949 . The right to a jury trial, Chafee noted, was "of much less value in times of war or threatened disorder when the herd instinct runs strong, if the opinion of the defendant is highly objectionable to the majority of the population, or cren to the particular class of men from whom or by whom the jury are drawn." Id. He referred specifically to the problems of jury selection in the prosecution of radicals. Id. at 949-50 \& n.60; cf. note 296 supra (discussing Freund's interpretation of Fox's Libel Act).

414. Chafee-Freedom of Speech in War Time, supra note 3, at 948; cf. p. 575 supra (discussing similar views of Schofield).

415. In Masses Publishing Co. v. Patten, 244 F. 535 (S.D.N.Y.), rev'd, 246 F. 24 (2d Cir. 1917), Judge Learned Hand rejected the bad tendency approach and promoted "direct incitement to violent resistance," $i d$. at 540 , as the proper standard for judging specch under the Espionage Act. Although Hand acknowledged the possibility that Congress could constitutionally "forbid the mails to any matter which tends to discourage the successful prosecution of the war," id. at 538, he repeatedly made clear his view that the Espionagc Act itself did not permit such a broad construction. "If one stops short of urging upon others that it is their duty or their interest to resist the law," Hand wrote, "it seems to me one should not be held to have attempted to cause its violation." Id. at 540; see id. at 539.42 (repeated rejection of bad tendency doctrine); Gunther, supra note *, at 724.29, $748-49$ (analyzing Hand's opinion and his subsequent correspondence with Chafee).

416. Chafee-Freedom of Speech in War Time, supra note 3, at $958 \mathrm{n} .85$ (citing Pound -Personality, supra note 239 , at 453-56).

417. Id. at 959-60. Compare id. at 959 with Pound-Personality, supra note 239, at 45354. Chafee asserted that most judges construing the Espionage Act considered only the in- 
Yet Chafee applied the technique of balancing to reach a very different result from Pound, who supported the punishment of hostile criticism of the government during the Civil War and limitations on "free expression of political opinions" by "ignorant" masses in congested cities. ${ }^{418}$ Chafee, relying instead on Hand's decision in Masses Publishing Co. and echoing Freund's approach in The Police Power, ${ }^{419}$ fixed the boundary line "close to the point where words will give rise to unlawful acts." 420 "The real issue in every free-speech controversy," Chafee concluded, is "whether the state can punish all words which have some tendency, however remote, to bring about acts in violation of law, or only words which directly incite to acts in violation of law."

\section{Chafee's Misrepresentation of Judicial Precedent}

Unlike the prewar scholars, however, Chafee ignored the tradition of judicial hostility to free speech that relied so heavily on the bad tendency theory. Before writing his article, Chafee had read every free speech case decided prior to $1916 .{ }^{422} \mathrm{He}$ had also read the prewar scholars who criticized contemporary judicial decisions. ${ }^{423}$ Yet Chafee maintained that the bad tendency test had disappeared in the United States after the adoption of the First Amendment, only to be "revived" by the prosecutions and decisions under the Espionage Act. According to Chafee, the Sedition Act of 1798 represented the only attempt in the history of the United States prior to 1917 to apply the bad tendency doctrine. ${ }^{424}$

Chafee peremptorily dismissed recent prewar decisions incompatible with his libertarian ideology. He rarely mentioned those cases and never discussed any in detail. ${ }^{425}$ Instead, he lamented that prior free

dividual interest in free speech, and ignored the more important social interest. Pound claimed that the individual interest had not been sufficiently recognized by public opinion. But both agreed on the central point: free speech had at times suffered unduly at the cxpense of social interests in security and order.

418. Pound-Personality, supra note 239, at 455; see p. 575 supra.

419. E. FreUnd, supra note 28, at 509-13; see pp. 572-73 supra. Hand's decision bore strong resemblances to Freund's discussion in The Police Power, as Stedman observed. Stedman Brief for Debs, supra note 378, at 73.

420. Chafee-Freedom of Speech in IVar Time, supra note 3, at 960; see id. at 960-62.

421. Id. at 948 .

429. Chafee-Thirty-Five Years, supra note 22, at 2; Chafee Statement, supra note 404.

423. Chafee Statement, supra note 404.

424. Chafee-Freedom of Speech in IVar Time, supra note 3, at 952.

125. For cxample, Chafee did not refer to Fox v. Washington, 236 U.S. 273 (1915), or Turner v. Williams, 194 U.S. 279 (1904), two key prewar decisions that addressed free speech claims, see pp. 534-38 supra. He did mention Mutual Film Corp. v. Industrial Comm'n of Ohio, 236 U.S. 230 (1915), Patterson v. Colorado, 205 U.S. 454 (1907), and Robertson v. Baldwin, 165 U.S. 275 (1897), see pp. 532-34, 539-40 supra (discussing these 
speech cases lacked sufficient rigor and were "too few, too varied in their character, and often too easily solved." A number of these unidentified precedents were "of very dubious value," Chafee added, because they totally ignored "the economic and political facts of our time." ${ }^{26} \mathrm{He}$ concluded that earlier decisions, by failing to formulate any principle for drawing "a boundary line around the right of free speech," left the judges who decided the Espionage Act cases without any guidance and therefore "allowed some of them to impose standards of their own and fix the line at a point which makes all opposition to this or any future war impossible." 427

Chafee never acknowledged that the Espionage Act decisions he attacked were consistent with the prewar cases he largely ignored and his predecessors heavily criticized. Despite the pervasive reliance on the bad tendency theory in Schenck, Frohwerk, and Debs, Chafee reached the entirely unsupportable conclusion that Holmes had used the words "clear and present danger" in Schenck to make "the punishment of words for their bad tendency impossible." According to Chafee, Holmes in Schenck "substantially agrees with the conclusion reached by Judge Hand, by Schofield, and by investigation of the history and political purpose of the First Amendment." 428 Chafee also did not point out that the prewar cases actually drew a tight boundary line that excluded, through the use of the bad tendency theory, much speech he thought should be protected. Such concessions would have weakened, perhaps irreparably, the libertarian argument he was trying to construct, particularly because the prewar decisions could not be attributed to the excesses of wartime excitement. It was Chafee, not the judges he criticized, who tried to impose a standard of his own. But he, unlike the judges, advocated one that would protect dissent even in time of war. In his discussion of the crucial bad tendency theory, Chafee allowed the passion of his

three cases). Chafee-Freedom of Speech in War Time, supra note 3 , at 937 n.10, 938 n.19, 939 n.25, 958 n.83. He also cited some prewar decisions by state courts. Id. at 940 n.29, 941 n.30.

Chafee's discussion of the relationship between the First Amendment and the postal power further illustrates his ingenious and disingenuous use of precedent. Chafee noted that the exclusion of publications from the mails constituted prior restraint and "ought to be subject to the requirements of free speech and due process of law." Id. at 970 . He then claimed, citing Ex parte Jackson, 96 U.S. 727 (1877), and Public Clearing House v. Coyne, 194 U.S. 497 (1904), see pp. 526-27 \& note 47 supra, that "there are dicta of the Supreme Court that [the postal power] is not unlimited." Chafee-Freedom of Speech in War Time, supra note 3 , at 970 \& n.133. This claim, to say the least, minimizes to a misleading extent the insensitivity to free speech manifested by the postal cases, including the two he cited.

426. Chafee-Freedom of Speech in War Time, supra note 3, at 944-45.

427. Id. at 959 .

428. Id. at 967 . 
personal commitment to a libertarian construction of the First Amendment to overwhelm disinterested scholarship. ${ }^{429}$

\section{The First Amendment Dissents by Holmes and Brandeis}

The decisions of the Supreme Court majority from Abrams $v$. United States through Whitney $v$. California extended the tradition of judicial hostility to free speech. ${ }^{430}$ The majority rejected all free speech claims, combining visceral hostility to radical manifestations of free speech ${ }^{431}$ with doctrinal reliance on the bad tendency theory. ${ }^{432}$ The factual variety of the earlier cases was missing during the postwar period, when prosecutions of anarchists and socialists monopolized First Amendment litigation. But in analysis and result, nothing had changed.

In one crucial respect, however, the Supreme Court decisions of the 1920s did depart from their predecessors. Justices Holmes and Brandeis, beginning with their dissent in Abrams, developed a theory of First Amendment interpretation that relied heavily on Chafee's writings and, especially as reformulated by Chafee, on many of the libertarian principles of prewar scholarship. Before the war, only an occasional dissent or concurrence challenged the monotony of restrictive, unanimous decisions. The opinions of Holmes and Brandeis from Abrams through Whitney, by contrast, afforded meaningful theoretical protection for free speech. .33 $^{43}$

429. Others have made analogous observations. See Auerbach, supra note 355, at 522-23; Gunthcr, supra note *, at 748; Prude, supra note 355, at $641-42$.

430. Although these opinions relied particularly on the Espionage Act trilogy of Schenck, Frohwerk, and Debs, they also cited prewar precedents with some frequency. Gilbert v. Minnesota, 254 U.S. 325, 330-31 (1920), cited Halter v. Nebraska, 205 U.S. 34 (1907), se't p. 531 supra. United States ex rel. Milwaukee Social Democratic Publishing Co. v. Burleson, 255 U.S. 407,411 (1921), cited the post office litigation from Ex parte Jackson, 96 U.S. 727 (1877), through Lewis Publishing Co. v. Morgan, 229 U.S. 288 (1913), see pp. 526-29 stupra. Gitlow v. New York, 268 U.S. 652, 666-68 (1925), cited Robertson, Patterson, Fox, and several lower court cases from before World War One, including People v. Most, 171 N.Y. 423, 64 N.E. 175 (1902), see p. 544 supra. Whitney v. California, 274 U.S. 357, 369, 371 (1927), cited Fox and referred generally to the cases cited in Gillow.

431. See, e.g., United States ex rel. Milwaukee Social Democratic Publishing Co. v. Burleson, 255 U.S. 407, 416 (1921); Gilbert v. Minnesota, 254 U.S. 325, 331 (1920); Schaefer v. United States, 251 U.S. $466,477,479$ (1920).

432. See, e.g., Whitney v. California, 274 U.S. 357, 371 (1927); Gitlow v. New York, 268 U.S. 652, 669, 671 (1925); Pierce v. United States, 252 U.S. 239, 244 (1920); Schaefer v. United States, 251 U.S. 466,479 (1920).

133. In Gilbert, Holmes concurred in the result while Brandeis dissented. 254 U.S. 325, 334 (1920). In Whitney, Brandeis wrote a concurring opinion in which Holmes joined. 271 U.S. 357, 372 (1927). As Bork has observed, this concurrence was really a dissent. Bork, supra note 261, at 23. In all the other major First Amendment cases beginning with Abrams, Brandeis and Holmes dissented together, except in Milwaukee Social Democratic Publishing Company, in which they wrote separate dissents. 255 U.S. 407, 417 (1921) (Brandeis, J., dissenting); id. at 436 (Holmes, J., dissenting). 
In Abrams v. United States, decided only eight months after Schenck, Sugarman, Frohwerk, and Debs, and only five months after the publication of Freedom of Speech in War Time, Holmes joined Chafee in recognizing truth as "the ultimate good desired." Just as Chafee stressed open discussion of differing views as the best method for sifting out truth from falsehood, Holmes maintained that truth "is better reached by free trade in ideas." ${ }^{34}$ In his initial Espionage Act opinions, Holmes had ignored the government's argument that the common law of seditious libel survived the First Amendment; in Abrams, consistent with the consensus of Chafee and many earlier scholars, he abrupily rejected this argument, stating simply that "[h]istory seems to me against the notion." ${ }^{355}$ In addition, Holmes first appeared to identify in Abrams the distinction between public and private speech that lay behind much of the prewar scholarly commentary on the First Amendment. Holmes indicated that "where private rights are not concerned," Congress has less power to punish speech. ${ }^{436}$ More generally, he included language that demonstrated, as his prior opinions had not, an appreciation for the value of free speech. Holmes now maintained that "Congress certainly cannot forbid all effort to change the mind of the country," ${ }^{437}$ and he referred to the First Amendment as a "sweeping command," 438 allowing only rare exceptions. No similar language had appeared in Schenck, Frohwerk, or Debs, or in Davis, Patterson, or Fox.

Brandeis, the author of most First Amendment dissents in the decade after Abrams, continued this incorporation of libertarian, scholarly views. In Schaefer $v$. United States, the first dissent he wrote, Brandeis stressed the importance of free expression of minority views, a concern that Chafee and the prewar scholars had identified. He warned that "an intolerant majority, swayed by passion or by fear, may be prone in the future, as it has often been in the past, to stamp as disloyal opinions with which it disagrees." 439 Giving a jury power to construe speech as false statements of fact rather than as

434. 250 U.S. 616,630 (1919).

435. Id. Holmes supported his view on seditious libel by pointing out that "the United States through many years had shown its repentance for the Sedition Act of 1798, by repaying fines that it imposed." Id. It is plausible, as Chafee suggested, that Holmes derived this justification from Roe's amicus brief in Debs. Letter from Zechariah Chafee, Jr., to Judge George W. Anderson (Dec. 5, 1922) (Zechariah Chafee, Jr., Papers, Box 14, Folder 1, Harvard Law School Library); see Roe Amicus Brief for Debs, supra note 379, at 40-42. This argument was not made in the briefs in Abrams.

436. 250 U.S. 616,628 (1919).

437. Id.

438. Id. at 631 .

439. 251 U.S. $466,495(1920)$; see id. at 482. 


\section{Prewar Free Speech}

expressions of opinion, he added in Pierce $v$. United States, "would practically deny members of small political parties freedom of criticism and of discussion in times when feelings run high and the questions involved are deemed fundamental." 440 In Whitney v. California, he reiterated that the First Amendment was designed to guard against "the occasional tyrannies of governing majorities." 441

Brandeis recognized as well the relationship between free speech and democratic government identified by so much of the previous legal scholarship. Even intemperate language, he stressed in Pierce, should not be construed to forfeit the "fundamental right of free men to strive for better conditions through new legislation and new institutions." 442 "In frank expression of conflicting opinion," he added in Gilbert v. Minnesota, "lies the greatest promise of wisdom in governmental action; and in suppression lies ordinarily the greatest peril." 43 The search for truth that Chafee emphasized in his "key" paragraph, ${ }^{44}$ moreover, was almost identically expressed by Brandeis in Whitney, in which he reasoned that free speech is "indispensable to the discovery and spread of political truth." ${ }^{45}$ Brandeis in Whitney, like Pound and Chafee before him, also identified various individual interests in free speech, ${ }^{446}$ yet he followed his scholarly predecessors in considering the social interest in speech to be even more important. Each citizen's freedom of expression, he claimed in Gilbert, is a duty as well as a right, "for its exercise is more important to the Nation than it is to himself." ${ }^{47}$ In addition, Brandeis maintained, as had most of the scholars, that repression of speech is "hazardous" and "menaces stable government." 448

As they adopted libertarian values, Holmes and Brandeis faced the difficult problem of dealing with the prewar judicial hostility to free speech and its continuation in their own Espionage Act decisions. Trapped in a tradition from which they wanted to escape, but reluctant to acknowledge that tradition or their own role in it, they followed the lead provided by Chafee's article.

440. 252 U.S. 239, 269 (1920).

441. 274 U.S. 357,376 (1927).

442. 252 U.S. 239,273 (1920).

443. 254 U.S. 325,338 (1920).

444. Chafee-Freedom of Speech in War Time, supra note 3 , at 956-57; see p. 587 supra (quoting from paragraph).

445. 274 U.S. 357, 375 (1927) (Brandeis, J., concurring). In Gilbert, Brandeis also referred to the "conquest of error by truth." 254 U.S. 325, 338 (1920).

46. 274 U.S. 357,375 (1927) (Brandeis, J., concurring).

447. 254 U.S. 325,338 (1920). In Whitney, Brandeis asserted, on behalf of the framers, that "public discussion is a public duty." 274 U.S. 357,375 (1927).

448. 274 U.S. at 375. 
Holmes, who met Chafee between Schenck and Abrams, ${ }^{449}$ and Brandeis, who cited Chafee repeatedly in his opinions, ${ }^{450}$ recognized the strategic possibilities of Chafee's misconstruction of "clear and present danger." They accepted as their own the libertarian meaning Chafee erroneously read into those words, and thus were able, beginning with $A$ brams, to reject the bad tendency theory and neglect the prewar cases while claiming fidelity to precedent. ${ }^{451}$ Throughout the 1920s, Holmes and Brandeis elevated "clear and present danger" to constitutional significance and clung to it as the doctrinal peg for the libertarian values it did not express when Holmes first used the phrase in Schenck.

\section{Conclusion}

As the Supreme Court majority itself began to accept a more libertarian interpretation of the First Amendment, Chafee's views, rein-

449. Harold Laski, who knew both Holmes and Chafee, arranged for them to meet during the summer of 1919. Laski had already given Holmes a copy of Chafee's article and looked forward to a good "fight." Letter from Harold Laski to Zechariah Chafee, Jr. (July 23, 1919) (Zechariah Chafee, Jr., Papers, Box 14, Folder 15, Harvard Law School Library). Referring to his conversation with Holmes, Chafee wrote, "It is clear from the way Justice Holmes talks that if he had been on the jury in the Debs case he would have voted for acquittal." Letter from Zechariah Chafee, Jr., to Judge Charles F. Amidon (Sept. 30, 1919) (Zechariah Chafee, Jr., Papers, Box 4, Folder 1, Harvard Law School Library). Holmes subsequently wrote that Chafee had "seemed unusually pleasant and intelligent." Letter from Oliver Wendell Holmes, Jr., to Sir Frederick Pollock (June 21, 1920), in 2 Holmes-Pollock Letrers 45 (M. Howe ed. 1941). He also described Chafee -Freedom of Speech in War Time, supra note 3, as "first rate." Letter from Oliver Wendell Holmes, Jr., to Harold Laski (Dec. 17, 1920), in 1 HolMes-Laski Letrers 297 (M. Howe ed. 1953).

450. See, e.g., Whitney v. California, 274 U.S. 357, 376 n.3, 377 n.4 (1927); United States ex rel. Milwaukee Social Democratic Publishing Co. v. Burleson, 255 U.S. 407, 431 n.1, 433 n.l (1921); Schaefer v. United States, 251 U.S. 466, 486 (1920). While working on Gilbert v. Minnesota, 254 U.S. 325 (1920), Brandeis' law clerk, Dean Acheson, corresponded with Chafee and obtained page proofs of chapter two of Chafee's Freedom of Speech. Letter from Zechariah Chafee, Jr., to Dean Acheson (Nov. 20, 1920) (L.D. Brandeis Papers, Box 5, Folder 12, Harvard Law School Library). Brandeis' dissent in Gilbert largely incorporated from Chafee's letter to Acheson the reasoning, conclusions, and authorities dealing with the issues of federal preemption of state law and protection of freedom of speech through the Fourteenth Amendment. 254 U.S. at 342-43. In preparing his opinion in Whitney, Brandeis took extensive notes on Freedom of Speech. See Handwritten notes (L.D. Brandeis Papers, Box 44, Folder 5, Harvard Law School Library). Brandeis, enclosing a copy of this opinion, wrote Chafee that he "will see how much I have borrowed from you." Letter from Louis D. Brandeis to Zechariah Chafee, Jr. (May 21, 1927) (Zechariah Chafee, Jr., Papers, Box 4, Folder 4, Harvard Law School Library).

451. Holmes took care in Abrams to point out that "I never have seen any" reason to doubt that the questions of law that alone were before this Court in the cases of Schenck, Frohwerk, and Debs . . . were rightly decided." Abrams v. United States, 250 U.S. 616, 627 (1919). In Gitlow, he claimed that the majority "departed from" the "clear and present danger" test in Abrams. Gitlow v. New York, 268 U.S. 652, 672-73 (1925). Brandeis, in accepting "clear and present danger" as a constitutional standard in his first dissent, called it "a rule of reason," Schaefer v. United States, 251 U.S. 466, 482 (1920); in Whitney, he acknowledged that this rule had not yet been clearly defined. Whitney v. California, 274 U.S. 357, 374 (1927). 


\section{Prewar Free Speech}

forced by the additional books and articles he published over more than three decades, ${ }^{452}$ achieved even greater prominence. Although several recent scholars have successfully refuted the meaning attributed by Chafee to the "clear and present danger" language in Schenck, his work is still considered the initial important analysis of the First Amendment. Professors and judges have generally ignored the scholarship on which Chafee himself had relied, and have accepted uncritically his misrepresentation of the judicial tradition before World War One. As a result, the earlier cases and scholars are essentially unknown.

Many of the libertarian views of the prewar scholars, inherited indirectly through Chafee, have now received judicial acceptance. The prewar cases, on the other hand, have little continuing impact because the ideology behind them has been replaced by a vastly increased judicial sensitivity to First Amendment values. ${ }^{453}$ But whatever their current influence, these earlier scholars and cases are important. The prewar tradition demonstrates that consideration of the meaning of the First Amendment did not end with Hamilton and Jefferson, only to be resumed over a century later by Hand, Chafee, Holmes, and Brandeis. Developments in the generation before World War One not only formed part of the intellectual history of the First Amendment; they contributed significantly to the elaboration of judicial doctrine in the crucial years following the war.

452. See, e.g., Z. Chafee, The Blessings of Liberty (1956); Z. Chafee, Free Sreech in the United States (1941); Z. Chafee, The Inquiring Mind (1928); Chafee, Book Review, 62 HaRv. L. Rev. 891 (1949) (reviewing Meiklejohn's Free Speech And Its Relation to Self-Government).

453. Some of these cases have been explicitly or effectively overruled by the Supreme Court. See notes $64,83,97,159,169,170,179,208 \& 272$ supra. A few of them, however, continue to be discussed in recent Supreme Court decisions. In fact, the occasions when prewar cases are now relied on provides a useful index of the extent to which the modern Court has decided not to adopt a more libertarian interpretation of the First Amendment. See, e.g., Richardson v. Ramirez, 418 U.S. 24, 53 (1974) (upholding disenfranchisement of ex-felons; citing Davis v. Beason, 133 U.S. 333 (1890)); Miller v. California, 413 U.S. 15, 28 n.10 (1973) (establishing "contemporary community standards" as test of obscenity; citing Fox v. Washington, 236 U.S. 273 (1915), for proposition that test not too vague for criminal law); Kleindienst v. Mandel, 408 U.S. 753, 762 (1972) (sustaining exclusion of Belgian Marxist professor invited to visit various American universities; citing Turner v. Williams, 194 U.S. 279 (1904), among other authorities, for proposition that unadmitted, nonresident alien has no constitutional right to enter United States); Communist Party of the United States v. Subversive Activities Control Bd., 367 U.S. 1, 97 n.39 (1961) (upholding registration requirement for "Communist-action organization"; citing Lewis Publishing Co. v. Morgan, 229 U.S. 288 (1913)); see note 198 supra (discussing Hatch Act cases that cite Ex parte Curtis, 106 U.S. 371 (1882)); cf. Spence v. Washington, 418 U.S. 405, 418-20 (1974) (Rehnquist, J., dissenting) (citing Halter v. Nebraska, 205 U.S. 34 (1907), to support constitutionality of conviction for attaching peace symbol to American flag). 


\title{
The Yale Law Journal
}

Volume 90, Number 3, January 1981

\author{
John M. Campbell
}

Editor-in-Chief

\author{
Michael D. Klausner \\ Note \& Topics Editor \\ Vincent J. Chiarello \\ Perry Dane \\ Stuart A.C. Drake \\ John D. Echeverria \\ Note Editors
}

David E. Van Zandt

Managing Editor

Carol F. Lee

Dwight G. Smith III

Richard G. Taranto

Kenneth S. Taymor

Donald J. Toumey

Article \& Book Review Editors
Tim Atkeson

Richard Bartlett

H. Craig Becker

Donald S. Collat

Kathleen Cully

Peter M. Daub

F. Tayton Dencer

Janet L. Dolgin

William V. Dunlap

Frances H. Foster

Charles W. Fournier

Robert D. Gilbert

George Harris
Russell Hayman

Hugh $\mathrm{H}$. Jacobson

Steven M. Kamp

Randall Kennedy

David B. Keto

Judith A. Lachman

Deborah Leavy

R. Gustave Lehouck II

Jonathan Macey

Robert L. McGlasson

Suzanne E. Meeker

Rachel F. Moran

Theodore A. Paradise

Russell G. Pearce
Ellen R. Porges

Jonathan E. Richman

Alfred O. Rose

Patrick W. Shea

Robert Silver

Steven A. Steinbach

Jeffrey W. Stempel

Lynn A. Stout

Alan Sykes

E. Michael Paul Thomas

Anne E. Verdon

David Wippman

George Wyeth

Assistants to the Editors Mary Ann McClure, Pamela Willmott

\section{Student Contributors to This Issue}

Judith A. Lachman, Daring the Courts: Trial and Bargaining Consequences of Minimum Penalties

R. Gustave Lehouck II, A Definition of Punishment for Implementing the Double Jeopardy Clause's Multiple-Punishment Prohibition

Suzanne E. Meeker, Equal Pay, Comparable Work, and Job Evaluation

Anne E. Verdon, A Damages Remedy for Abuses by Child Protection Workers 